Ministerstwo Nauki

i Szkolnictwa Wyższego

Digitalizacja archiwalnych numerów czasopisma naukowego Analecta Cracoviensia 1-24 (1969-1992) i ich publikacja w otwartym dostępie - zadanie finansowane w ramach umowy 672/P-DUN/2017 ze środków Ministra Nauki i Szkolnictwa Wyższego przeznaczonych na działalność upowszechniającą naukę

\title{
KRÓLOWA JADWIGA W TRADYCJI KAZNODZIEJSKIEJ XV WIEKU
}

W obecnym stanie badań znanych jest 9 kazań z XV wieku, poświęconych osobie królowej Jadwigi ${ }^{1}$. Ich autorami byli profesorowie Uniwersytetu Krakowskiego, a mianowicie:

1. Stanisław ze Skarbimierza - kazanie na pogrzeb Królowej w r. 1399.

2. Jan Isner - kazanie z roku 1399 lub 1400.

3. Stanisław ze Skarbimierza - kazanie rocznicowe z r. 1401 lub 1409.

4. Franciszek z Brzegu - kazanie rocznicowe $z$ r. 1420.

5. anonimowe, powstałe między r. 1422 a 1426.

6. Franciszek z Brzegu - kazanie rocznicowe prawdopodobnie $z r$. 1426.

7. Jan Elgot - kazanie rocznicowe napisane około r. 1428.

8. Paweł z Zatora - kazanie rocznicowe napisane około $1430 \mathrm{r}$.

9. anonimowe, napisane około $1443 \mathrm{r}$.

Uniwersytet Krakowski każdego roku uroczyście obchodził aniwersarz śmierci królowej Jadwigi ${ }^{2}$. Z tej okazji, w czasie mszy św. żałobnej kaznodzieja uniwersytecki głosił kazanie na wybrany temat teologiczny, najczęściej o śmierci i grzechu. Obok treści teologicznej, która zasługuje na osobne opracowanie, autorzy we wstępie kazania (prothema) lub w jego zakończeniu (unitio) poświęcali Królowej wiele miejsca, wspo-

1 Listę tych kazań, z wyjątkiem tekstu 2 i 5, zestawiła M. Kowalczyk w pracy: Krakowskie mowy uniwersyteckie $z$ pierwszej polowy XV wieku, Wrocław 1970 , $119-136,181-186$. Autorce, za liczne informacje udzielone nam $w$ toku przygotowywania poniższej publikacji, składamy serdeczne podziękowanie.

2 Por. M. Kowalczyk, jw., 119. 
minając jej zasługi i wzywając do modlitwy za jej duszę. W takiej uroczystości żałobnej brał udział cały Uniwersytet, dwór królewski ${ }^{3}$, a z kleru katedralnego przynajmniej kolegium wikariuszy i psałterzystów (tych ostatnich ufundowane, jak wiadomo, przez Jadwigę). Uniwersytet obchodził aniwersarze śmierci również tych osobistości, które zasłużyły się dla jego rozwoju. Do nich należeli wybitni profesorowie lub dobroczyńcy ${ }^{4}$. Najliczniejsze świadectwa o tych aniwersarzach odnoszą się jednak do królowej Jadwigi.

W czasie żałobnej liturgii w rocznicę jej śmierci istniała sposobność do pielęgnowania pamięci wielkiej fundatorki uniwersyteckiej. W tamtej epoce kazania na rocznicę śmierci były najlepszym środkiem publicznego przekazywania wiadomości o zmarłej Królowej. Kazania uniwersyteckie do magistrów i studentów różnych narodowości były zawsze głoszone w języku łacińskim i należały do programu nauczania, jako jedna $\mathrm{z}$ form kształcenia studentów w sztuce kaznodziejskiej i w wykładzie poprawnej doktryny katolickiej, której Uniwersytet był stróżem. Dzięki tym kazaniom studenci wynosili więc z Krakowa wiadomości o świątobliwej fundatorce Uniwersytetu, o jej grobie i kulcie w katedrze wawelskiej.

Uniwersytet wspominał jeszcze Jadwigę w wypominkach, czytanych w czasie nabożeństw za żywych i zmarłych dobrodziejów i profesorów Uniwersytetu ${ }^{5}$.

Nie zapominali o Jadwidze również nowo kreowani bakałarze. W zakończeniu, czyli w tzw. gratiarum actio, swego wykładu wstępnego do Biblii lub Sentencji Piotra Lombarda składali podziękowanie swoim profesorom, dobrodziejom i opiekunom, a także wspominali fundatorów uniwersyteckich, przede wszystkim Królową Jadwigę ${ }^{6}$.

3 O uczestnictwie króla w nabożeństwie żałobnym w rocznicę śmierci Jadwigi donoszą rachunki dworu: Item feria quinta ipso die s. Allexi [17 VII 1477] doctoribus et magistris universitatis celebrantibus exequias olim serenissime domine Hedwigis, regine Polonie, serenissimo domino dedi pro offertorio 〈exeq〉uiarum tres fertones - - (Rachunki królewskie z lat 1471-1472 i 1476-1478. Opr. S. Gawęda, Z. Perzanowski, A. Strzelecka, Wrocław 1960, 164).

4 Por. M. Kowalczyk, jw., 119.

5 Forma takiej kommemoracji w wypominkach była na ogól jednakowa. Oto ich treść z lat 1408 do 1458; z r. 1408: Item pro domina regina pie memorie huius Universitatis renovatrice et benefactrice - - (Album studiosorum Universitatis Cracoviensis. Ed. Ż. Pauli, Cracoviae 1887, t. 1, 8-9; M. Kowalczyk, Wypominki Uniwersytetu Krakowskiego z lat 1431/32, 1453 i 1458. „Studia Warmińskie". T. 9: 1972, 523); z r. 1431/32: Dum inter mortuos recomendo vobis serenissimam dominam Hedvigim olim reginam Poloniae, fundatricem, huius Universitatis - - (jw., 528); z r. 1453 i 1458: Similiter pro defunctorum animabus oremus - - Singulariter tamen pro anima serenissime domine Hedvigis, olim regine Polonie, fundatricis huius Universitatis (jw., 530, 533).

6 Tak uczynił np. Andrzej z Kokorzyna w wykładzie wstępnym do Sentencji P. Lombarda - por. Z. Kozlowska-Budkowa, Uniwersytet Jagielloński $w$ dobie Grunwaldu. „Zeszyty Naukowe Uniwersytetu Jagiellońskiego. Prace Historyczne 8”, Kraków 1961, 66. 
Tak więc Uniwersytet Krakowski był podówczas jedyną społecznością kultywującą w potrójny sposób tradycję o Jadwidze: (1) przez żałobne nabożeństwa w rocznicę jej śmierci; (2) w wypominkach na wspólnyeh mszach za dobrodziejów; (3) podczas wykładów wstępnych, w tzw. gratiarum actiones, wygłaszanych przez bakałarzy. Najważniejszym wszakże aktem wdzięczności Uniwersytetu wobec jego Fundatorki były aniwersarze, zawsze uświetniane okolicznościowym kazaniem.

$\mathrm{Z}$ taktem i umiarem, bez płaskiej dewocji i szablonowego panegiryzmu przedstawiali $w$ swoich kazaniach postać Królowej różni profesorowie uniwersyteccy. Stanisław ze Skarbimierza, Jan Isner, Franciszek z Brzegu, Jan Elgot, Paweł z Zatora, autorzy najstarszych kazań o Jadwidze, to znani skądinąd profesorowie krakowskiej Almae Matris. Trzej pierwsi należeli do pierwszej generacji uczonych i pedagogów, która mogła osobiście śledzić równie niezwykłe życie jak i działalność młodej Królowej. Oni też nadali organizacyjny kształt jej wielkiemu dziełu, tzn. Uniwersytetowi. Najpiękniejsze świadectwo o zmarłej Pani pozostawił Stanisław ze Skarbimierza - prawdopodobnie jej spowiednik. We wszystkich jednak wypowiedziach innych autorów, jakie poniżej zamieszczamy daje się wyczuć prawdziwy autentyzm uczuć pokolenia, które ciągle jeszcze przeżywało tragizm odejścia Królowej. W tekstach swoich przedstawiają również rozwój osobowości i formacji duchowej Jadwigi, ujęty w świetle obowiązujących kryteriów teologicznych.

Opinia świętości otaczająca królowę Jadwigę od chwili jej zgonu sprawiła, że w r. 1426 na polecenie abpa W. Jastrzębca została powołana komisja do spisania i zbadania cudów dziejących przy grobie Andegawenki. W skład tej komisji wchodzili $\mathrm{m}$. in. Stanisław ze Skarbimierza, Paweł Włodkowic, Piotr Wolfram, Paweł z Zatora i inni ?. Echo tych ivydarzeń pobrzmiewa w kazaniu Franciszka z Brzegu (6).

Zagadnienie tradycji kaznodziejskiej o królowej Jadwidze ilustrujemy oryginalnymi tekstami kazań. Spośród dziewięciu wymienionych zabytków ogłaszamy $\mathrm{w}$ pełnym brzmieniu trzy teksty $(1,5,6)$, napisane między rokiem 1399 a 1426 . W ten sposób rejestrujemy najstarszą tradycję, przekazaną przez pierwsze pokolenie profesorów Uniwersytetu Krakowskiego. Z pozostałych przytaczamy jedynie fragmenty, zawierające wiadomości o osobie Królowej. Opuszczamy zaś kazanie 4, wykorzystane przez Franciszka z Brzegu w tekście z r. 1426.

Łacińską edycję kazań i ich polski przekład przygotował R. M. Zawadzki przy współpracy J. Wolnego, autora not edytorskich i historycznych objaśnień do cytowanych tekstów.

7 Por. Monumeta Poloniae Historica, Lwów 1884 (Warszawa 1961), t. 4, 765. 
S I G L A

CODICUM MANUSCRIPTORUM LAUDATOS DE HEDVIGE REGINA POLONIAE SERMONES CONTINENTIUM

G - Ms. 381 Archivi Archidioecesani Gnesnensis

$J^{1}$ - 173 Bibliothecae Jagellonicae Cracoviae

$\mathrm{J}^{2}-191$ Bibliothecae Jagellonicae Cracoviae

$\mathrm{J}^{3} \quad-723$ Bibliothecae Jagellonicae Cracoviae

$\mathrm{J}^{4} \quad 1272$ Bibliothecae Jagellonicae Cracoviae

$\mathrm{J}^{5} \quad-2372$ Bibliothecae Jagellonicae Cracoviae

S - C. 428 Bibliothecae Seminarii Sandomiriensis

W - I Q 381 Bibliothecae Universitatis Vratislaviensis 


\section{CONSPECTUS SERMONUM}

I. STANISLAI de SCARBIMIRIA, ,Sermo ad regem et proceres eius de obitu Hedvigis reginae et vita eius" (a. 1399).

Textus latinus integer una cum translatione polonica.

II. (Anonymi) „Sermo in anniversario venerandae Hedvigis, reginae Poloniae, ipsa die beati Alexii confessoris" (circa a. 1422). Textus et translatio, ut supra.

III. FRANCISCI de BREGA ,Sermo in exequiis dominae Hedvigis, reginae Poloniae" (circa a. 1426).

Textus et translatio, ut supra.

IV. IOANNIS INSERI „Sermo ad clerum de obitu reginae Polonorum” (circa a. 1400).

Argumentum.

V. STANISLAI de SCARBIMIRIA ,Sermo latinus in exequiis dominae Hedvigis, reginae Poloniae" (circa a. 1401).

Fragmentum textus eiusque translationis polonicae.

VI. IOANNIS ELGOT "Sermo in recommendatione Hedvigis reginae" (circa a. 1428).

Fragmentum textus eiusque translationis, ut supra.

VII. PAULI de ZATOR Serma de Hedvige regina (circa a. 1430).

Fragmentum textus eiusque translationis, ut supra.

VIII. (Anonymi) Serma de Hedvige regina (circa a. 1443).

Fragmentum textus eiusque translationis, ut supra. 
[STA NISLAI de SCARBIMIRIA]

\author{
SER M O \\ AD REGEM ET PROCERES EIUS \\ DE OBITU HEDWIGIS REGINAE ET VITA EIUS
}

Dominus mortificat et vivificat, deducit ád inferos et reducit.

$1 \operatorname{Reg} 2,6$

Immortalis Deus et immensus fecit hominem rationalem, fecit optime proportionatum et complexionatum, fecit talem, quod si non peccasset, semper viveret, semper vivendo semper Deo adhaeret, semper adhaerendo ei, qui immortalis est. Et ipse vitam sine ullo termino possideret, nec umquam mortis amaritudinem degustaret; longe namque ab ipso, si non peccasset, fuisset infirmitas, longe naturae languor, longe poenalitas, longe fletus, longe tristitia, longe quaevis debilitas. Verum, quia pec15 cavit homo, amotus est a Deo, eiectus de paradiso, remotus a guadio et proscriptus a facie Domini. Mansit vagus et profugus super terram, contra quem in continenti post peccatum omnia bellare coeperunt: iam caelum, iam terra, iam aer, iam ignis, iam aqua, iam intempestas aeris, iam aestus, iam calor, iam timor, iam tremor, iam luctus, iam planctus, ita

20 quod nec esset aliquid, quod contra ipsum hominem non pugnaret. Factumque est - ut esset quasi de iure et lege peccati - quod omnia turbent hominem, omnia premant, omnia vexent et quod diversis pressus homo tristitiis, diris infirmitatibus, non habeat quo respiret, quo fulciatur, sed semper habeat quo laboret, quo decrescat, quo occidat. In se et $J^{2} f .105 v a$ ex se habeat | bellum, utpote in quo pugnant elementa: pugnat frigidum cum calido, humidum cum sicco tam diu, donec dissolvant animae cum corpore unionem. Quod considerans propheta, dicebat [Ps 88, 49]: Quis est homo, qui vivet et non videbit mortem? - quasi dicerét: nullus, quia de lege peccati venit mors.

* Textus sermonis in solo tantum manuscripto $\mathrm{J}^{2}$ (f. $105 \mathrm{ra}-107 \mathrm{rb}$ ), alia quoque scripta Stanislai de Scarbimiria continenti, in Bibliotheca Jagellonica Cracoviae asservatus est. Hunc codicem ignotus librarius circa annum 1415, ut putatur, confecit. Sermo autem ille funebris lugubri die (19 Iulii 1399) exequiarum HEDVIGIS, reginae Poloniae et olim consortis Vladislai III, in ecclesia cathedrali Cracoviensi pronuntiatus erat a Stanislao de Scarbimiria, clarissimo doctore decretorum et primo renovatae, secundum extremam HEDVIGIS voluntatem, anno sequenti (1400) Universitatis Cracoviensis rectore magnifico. De illo auctore eiusque operibus confer libros infra laudatos (p. 31).

22 permant [correxi] prement $m s$.

25-26 in quo pugnant - cum sicco, cf. Ovidii Metamorphoses 1, 18 sq.: quia corpore in uno, frigida pugnabant calidis, umentia siccis. 
[STANISEAWA ze SKARBIMIERZA]

\author{
K A Z A N I E \\ PRZED KRÓLEM I JEGO DOSTOJNIKAMI \\ O SMIERCI I ŻYCIU KROLOWEJ JADWIGI
}

Pan daje śmierć i życie, w grób
wtrąca i zeń wywodzi
1 Krl. 2,6

Nieśmiertelny i nieograniczony Bóg uczynił człowieka istotą rozumną, uczynił go niezwykle kształtnym i harmonijnie zbudowanym, uczynił go takim, że gdyby człowiek nie dopuścił się grzechu, zachowałby życie wieczne, żyjąc zaś nieustannie, na zawsze przylgnąłby do Boga, na zawsze przylgnąłby do tego, który jest nieśmiertelny. Życie jego trwałoby bez końca i nigdy by nie zaznał goryczy śmierci; albowiem - gdyby nie zgrzeszył - z dala od niego trzymałyby się choroby, $z$ dala wrodzone słabości i skłonność do występku, z dala odeń byłyby łzy, z dala smutek, z dala jakakolwiek ułomność. Ale człowiek popełnił grzech i dlatego został odepchnięty przez Boga, wyrzucony $z$ raju, pozbawiony radości, odsunięty sprzed oblicza Pańskiego. Pozostał tułaczem i wygnańcem na ziemi, gdzie na skutek grzechu wszystko niebawem wypowie-działo mu wojnę: i niebo i ziemia, powietrze, ogień i woda, burze, spiekota i upał, lęk i trwoga, smutek i rozpacz, aż w końcu nie było już niczego, co by nie stanęło do walki przeciw człowiekowi. I rzeczywiście, niejako prawo i zasada grzechu sprawiły, że wszystko teraz wywołuje w człowieku niepokój, wszystko go uciska i dręczy, on zaś trapiony różnymi smutkami, ciężkimi chorobami nigdzie nie znajduje wytchnienia, nigdzie oparcia, ale bez ustanku musi się trudzić, opada $z$ sił, ginie. W sobie i przez siebie toczy walkę, jako że w nim zmagają się żywioły: zimno $\mathrm{z}$ gorącem, wilgoć $\mathrm{z}$ suchością, dopóki nie zostaną zerwane więzy łączące duszę z ciałem. Rozważając to, prorok powiada [Ps. 88, 49]: Czyż jest jakiś człowiek, który by żył a nie widział śmierci? — jakby mówił nie ma takiego, ponieważ prawem grzechu przychodzi śmierć. 
Et cum simus omnes peccatores et omnes quasi oves sine pastore erramus unusquisque in viam suam, unusquisque ad inventionem suam, omnes nos mori est necesse. Si ergo unusquisque cursum suum con-

5 siderat quo transitum, quo pergit, non miratur, quod terminum videt; quem indubitanter venire sperat. Unde nec timere debet, quod omnino vitare non potest. Si enim qualibet res gaudet suo privilegio, sua lege et regula, et mors, quae emanavit ex peccato, cum habeat privilegium et ius quoad omnes, ut conservetur in suo iure, est necesse.

10 Et quia nemini facienda est iniuria, laeto animo unusquisque suum finem exspectet et consolationem ideo habeat, quia certissimum habemus depositum in Domino, qui nobis reposuit coronas iustitiae velut iustus iudex. Ipse enim est, qui mortificat dum vult, vivificat quando vult, deducit ad inferos sicut vult et reducit, et collocat ubi vult. Ipse,

15 inquam, mortificat, quia mori nos sinit, dum natura nostra in suo iure $J^{2} f .105 v b$ servata dissolvit, sed vivificat nos per suam gratiam, quia decet | summe esse bonum, ut ex quo sibi tam in corpore quam in anima militamus, etiam utriusque retributionem capiamus. Ipse est, qui deducit ad inferos purgatorii quos novit necesse purgari, quia Dei iustitia nihil mali relin-

20 quit impunitum, et reducit purgatos, ut recipiant condignam pro meritis responsionem. Et quia Dominus mortificat, servus dicere non audeat: Quare facis? Non congruit enim servo, ut compellat dominum facere, quid servo libeat. Si Dominus mortificat, ipse est, qui et vivificat. Si servus tristatur de morte, sit laetus de vita; si pavet inferos, confidat se

25 posse reduci ad caelos. Si imperator secrete et insperate quem vocat, ut pro meritis coronam recipiat, non est rationabile, quod illum quis lugeat, quem coronandum corona immortali posse confidat. Sed est de nobis mirabile, dum vocamur a Domino: renitimur, si possemus appellare cuperemus si prororogare, si nos excusare, si aliquas indutias impetrare,

30 et venimus ad Deum inviti, a quo volumus caelestibus praemiis coronari. Cotidie petimus, quod adveniat regnum suum, quod fiat voluntas sua et tamen dum voluntas sua est, quod mortificet, ut tandem vivificet et ad caelestia perducat, tristamur et procidimus in lamenta.

$\mathbf{J}^{2} \mathrm{f} .106 \mathrm{ra} \quad$ Fateor tamen | non esse prohibendos homines propter humanitatis affectum pias, sed cum moderamine, impendere pro mortuis lacrimas, cum legamus et sanctos et sanctum sanctorum, dominum nostrum Ihesum Christum easdem pias lacrimas impendisse. Ex desperatione tamen vitae futu-

12-13 qui - - iudex, cf. 2 Tim 4, 8: In reliquo reposita est mihi corona iustitiae, quam reddet mihi Dominus in illa die iustus iudex. 
My zaś, skoro wszyscy jesteśmy grzesznikami i wszyscy błądzimy jak owce bez pasterza, każdy swoją drogą, każdy według własnego upodobania, przeto. wszyscy musimy pomrzeć. Jeśli zatem każdy zastanowi się dokąd zawiodła go własna droga i dokąd prowadzi, nie zdziwi się, że widzi jej kres, do którego bez wątpienia spodziewa się dotrzeć. Dlatego człowiek nie powinien żywić obawy, że nie można tego wcale uniknąć. Jeśli jakaś rzeç sprawia przyjemność uprzywilejowaniem, swą właściwością i zasadą, to również śmierć, zapoczątkowana przez grzech, posiadając szczególne uprawnienia w stosunku do wszystkich ludzi, musi zachować te swoje przywileje.

Lecz żeby nixt nie dounał przyłkrości, niech każdy spokojnie oczekuje swego końca i to niech będzie dla niego pociechą, że najpewniejszą rękojmię złożył w Panu, który jako prawy sędzia przeznaczył dla nas wieniec sprawiedliwości. On to bowiem kiedy chce zsyła śmierć i daje życie, według swej woli wtrąca do grobu i zeń wyprowadza, gdzie chce tam wyznacza człowiekowi dowolne miejsce. Powiadam on sam zsyła śmierć, ponieważ godzi się abyśmy umierali, gdy zachowując prawo przyrodzone uwalnia nas odeń, ale też daje życie dzięki swojej łasce, ponieważ jest rzeczą ze wszech miar godziwą, aby nasze ciało jak i dusza zostały wynagrodzone za walkę, jaką w nich toczymy. On jest także tym, który wiedzie do głębokości czyśćca wszystkich wymagających oczyszczenia - Boska sprawiedliwość nie pozostawia żadnego zła bez kary - oczyszczonych zaś wyprowadza, aby odebrali stosowną do ich zasług nagrodę. Skoro jednak Pan zsyła śmierć, sługa nie ośmieli się Go zapytać: Dlaczego tak czynisz? Nie przystoi bowiem słudze przymuszać Pana, aby spełniał upodobania sługi. Jeśli Pan daje śmierć, jest również tym, który daje życie. Kiedy sługę zasmuca myśl o śmierci, niech raduje się z życia; gdy przeraża go piekło, niech wierzy w możliwość powrotu do nieba. Jeśli władca wzywa kogoś niespodziewanie i potajemnie, aby ten odebrał nagrodę za swe zasługi, to bezrozumnie czyni ktoś, jeżeli takiego opłakuje, wierząc przy tym, że ten może być nagrodzony koroną nieśmiertelności. Ale rzecz dziwna, że gdy zostajemy wezwani przez Boga, to ociągamy się i gdybyśmy tylko mogli, chętnie złożylibyśmy odwołanie, odkładali termin, wymawiali się, grali na zwłokę, aż w końcu po niewoli przychodzimy do Boga i chcemy, aby nas nagrodził niebiańskimi koronami. Co dzień prosimy, aby przyszło Jego królestwo, aby stała się Jego wola, a kiedy wreszcie ta wola dokonuje się i zjawia się śmierć po to, by zrodziło się życie, by przybliżyło się niebo, przepełnia nas smutek i żal głęboki. 
rae aut ingratitudinis plorare pro mortuis non congruit, cum sciamus ipsos non amitti sed praemitti, ut loquitur Cyprianus, et praesertim cum nec Deus Pater Filio suo Unigenito pepercit, quando pro nobis in mortem tra-

5 deret illum. Cum Filius sibi ipsi non perpercit, quin daret animam suam pro nobis, cum Spiritus Sanctus Dei Filium calore suo tam calefecit, quod eodem accensus pro salute nostra crucis subiret patibulum, non est congruum petere, quod parcat homini, ex quo Deus pepercit Filio amplius. Si non pepercit patri nostro, non parcet filiis, si non pepercit prioribus,

10 non parcet posterioribus. Aequa enim debet esse nostra cum illis condicio, quia cum hereditatem patrum nostrorum hereditavimus, latius iuris quasi nobis a patribus nostris relictum est non habemus.

Cernat igitur Regalis Maiestas, cernat et quaevis alia nobilitas, quod quoad introitum et exitum, mortem et resurrectionem futuram aequali-

15 ter currunt rex et miles, latro et princeps, simul in unum dives et pau$\mathbf{J}^{\mathbf{f}} \mathbf{1 0 6} \mathrm{rb}$ per. Cernant et singuli, | quod non fecit nobis iniuriam, quod dominam nostram HEDWIGYM, reginam quondam Poloniae, ad se vocavit. Dominus enim est iustus et sanctus. Quidquid facit est rectum, quilquid vult est sanctum. Nec est facta sibi iniuria, quia secundum Senecam taliter

20 in hunc mundum intravit, ut exiret. Fateor siquidem, quod oravimus, quod ploravimus, immo, ut ita dicam, clamor noster in caelum ascendit, ut ipsam Dominus Deus pro decore regni Poloniae, pro statu tranquillo, pro speciali clenodio pro, refrigerio viduarum, pro consolatione pauperum, pro relevamine oppressorum, pro reverentia pontificum, pro recursu

25 sacerdotum, pro firmamento pacis, pro testamento et tutela divinae legis conservasset, nec tamen quod conservata in vita fuisset obtinuimus. Oravimus nempe, quia sicut vidimus, sicut audivimus in civitate Domini et in monte sancto eius, sicut conspeximus in ecclesiis, in altaribus, in ornamentis, in signis, in consiliis, in operibus sic obtinuimus.

30 Vidimus enim quod fuit mater spiritualium, benefactrix viduarum, consolatio orphanorum, clipeus pauperum, refugium oppressorum, interventrix a facie domini nostri regis expulsorum. Quos enim quandoque formido domini nostri regis et sua iustitia exterruit, hos ipsa suo interventu laetificavit. Vidimus quam sagax fuit in consillis, quam provisa in

35 negotiis, quam nitente ea, quae erant coronae Poloniae, pro posse sua (?) $\mathrm{J}^{\mathrm{z}} \mathrm{f} .10 \mathrm{va}$ conservare nitebatur. Vidimus et cognovimus | quam decora vultu, quam affabilis affatu, quam nobilis genere, sed nobilior moribus, quam profunde humilis, licet multum fuisset sublimis. Vidimus, quo modo insig-

27-28 in civitate - - eius, cf. Ps 47, 2: Magnus Dominus et laudabilis nimis, in civitate Dei nostri in monte sancto eius. 
Przyznaję, że ludziom powodującym się szczerym odruchem uczucia, nie można zakazać wylewania $\mathrm{z}$ umiarem serdecznych łez za zmarłymi, skoro czytamy, że zarówno święci, jak i święty nad świętymi, Pan nasz Jezus Chrystus, rzewne ronili łzy. Nie godzi się wszakże opłakiwać zmarłych zwątpiwszy w przyszłe życie albo w niewdzięczność z ich strony, skoro wiemy, że nie zostali oni straceni na zawsze, a tylko wyprzedzili nas w drodze, jak powiada Cyprian, zwłaszcza że Bóg Ojciec nie oszczędził swego jednorodzonego Syna, skoro wydał Go za nas na śmierć. To też, kiedy Syn nie oszczędził siebie samego, ale oddał za nas swoje życie, gdyż Duch Swięty tak bardzo rozpalił ogniem swej miłości Syna Bożego, że ten nią pobudzony podjął brzemię krzyża dla naszego zbawienia, przeto niestosowną rzeczą byłoby domagać się, aby Bóg oszczędził człowieka, kiedy wcale nie oszczędził swego Syna. Jeżeli nie oszczędził ojców naszych, nie oszczędzi i synów; jeżeli nie oszczędził przodków, nie oszczędzi potomków. Albowiem związani jesteśmy tym samym co i oni układem, ponieważ dziedzicząc ojcowiznę, nie mamy szerszych uprawnień od tych, jakie pozostawili nam ojcowie nasi.

Zauważ Wasza Królewska Wysokość i wy wszyscy dostojni panowie, że od chwili narodzenia do momentu zgonu jednakowo ku śmierci i przyszłemu zmartwychwstaniu zmierza król i żołnierz, najemnik i wódz, pospołu bogacz i żebrak. Niech przeto każdy zrozumie, że Bóg nas nie skrzywdził, wzywając do siebie naszą panią JADWIGE, niegdyś królowę Polski. Pan wszelako jest sprawiedliwy i święty. Cokolwiek uczynił jest sluszne, czegokolwiek chce jest święte. A zatem nie wyrządził jej krzywdy, gdyż - jakby to powiedział Seneka - w taki sposób na ten świat przyszła, w jaki go opuściła. To prawda, że wśród łez zanosiliśmy nasze modlitwy i powiem nawet, że wołanie nasze wznosiło się ku niebu, aby nam Pan Bóg zachował tę ozdobę królestwa polskiego, ostoję ładu państwowego, ten klejnot niezwykły, to ukojenie wdów, tę pociechę nędzarzy, to wspomożenie uciśnionych, poszanowanie dostojników Kościoła, tę ucieczkę kapłanów, to umocnienie pokoju, świadectwo i osłonę prawa Bożego - a mimo to nie wybłagaliśmy utrzymania jej przy życiu. Modliliśmy się przecież, bo tak jakbyśmy ją widzieli i słyszeli w mieście Pana naszego i na świętej jego górze [por. Ps. 47, 2], tak też dostrzegając jej obecność po kościołach, na ołtarzach, w ozdobach, w znakach cudownych, w radach i uczynkach, taką ją zachowaliśmy w pamięci.

Widzieliśmy bowiem, że była matką duchownych, dobrodziejką wdów, pocieszycielką sierot, tarczą ubogich, ucieczką pokrzywdzonych, orędowniczką odsuniętych sprzed oblicza naszego króla. Tym wszelako, których niegdyś lękiem napełniła osoba króla i przerażała jego sprawiedliwość, ona swoim osobistym wstawiennictwem przynosiła radosną ulgę. 
nivit ecclesiae, induit aras, fundavit altaria, qualiter honoravit principes, qualiter nobiles, qualiter pontifices, qualiter sacerdotes, quo modo pie recepit pauperes, quo modo dabat piam audientiam, qualiter non insultabat alicui: non rixosa, non verbosa, non iracunda, nisi ubi oportuisset. Multa vidimus, multa cognovimus, plura vidissemus, si placuisset ulterius Deo nostro ipsam in suis naturalibus conservasse.

Haec igitur sint vobis pro planctu, haec et pro remedio, quia si talem dolemus mortuam, gaudere debemus talem fuisse vivam, quae talem se exhibuit, quod laus sua non deficiet de ore hominum. Scripta enim est,

10 ut pie credo, in caelestibus, scripta est in fidelium cordibus, scriptum est nomen suum in libro vitae. Digna fuit et ideo ad dignum transivit. Regnum exilium putavit et ideo de hac valle lacrimarum ad caelestia convolavit. Pacem fecit et ideo in pace factus est locus eius et in Syon habitatio eius. Quaesivit honorem Dei et ideo laetitia sempiterna super

15 caput eius. Dilexit militantem Ecclesiam et ipsam quantum potuit pro-texit et ideo de militanti migravit in triumphantem, prout pie credendum est. Inflammavit per bona opera corda spiritualiter viventium et ideo, $J^{2} f .106 \mathrm{vb}$ quamvis in aliquo pro fragilitate humana esset | neglecta, orationibus tamen ipsorum suffulta iam consecuta est vel cito finalem saltem beatitu-

20 dinem consequetur. Inpendit misericordiam et benignitatem degentibus et ideo misericors et miserator Dominus, antequam finis suus venit, dedit sibi escam vitalem, escam sacramentalem. In alto residens profecit in patientia, multa namque dissimulavit, quae dum exterminare non potuit, patienter sustinuit. Et ut ipsius amplior probaretur patientia, visi-

25 tata est ex alto diris infirmitatibus, diversis languoribus et probata temptationibus sicut aurum in fornace.

Non ergo lugeat Regalis Serenitas sine moderamine, immo gaudeat talem se habuisse consortem et talem pro regno advocatam praemisisse. Clerus et populus, etsi luget ex recessu et carentia ipsius personali, res-

30 piret tamen, quia viam transiret communem, viam tritam communiter, a qua nullus excipitur, viam quam transire oportuit, viam qua itur et pervenitur ad Deum, quia ad Dei facialem visionem non nisi per mortis amaritudinem pervenitur. Viam ivit, quam Deus ire mandavit, qui mortificat et vivificat, deducit ad inferos et reducit. Recessit a nobis et ivit,

35 ubi hereditas est nostra. Spero siquidem, quod Deus, quem amavit, in quem credidit, quem dilexit, pro regno momentaneo - aeternum, pro

13-14 in pace - - habitatio eius, cf. Ps 75, 3: Et factus est in pace locus eius et habitudo eius in Sion.

14-15 laetitia - - eius, cf. Is 35, 10: - - et venient in Sion cum laude et laetitia sempiterna super caput eorum. 
Widzieliśmy jak roztropną była $w$ radzie, jak przewidującą $w$ przedsięwzięciach, z jaką gorliwością starała się zachować wszystko, co umacniało potęgę Korony Polskiej. Widzieliśmy i poznaliśmy jej niezwykłą urodę, jej ujmujący sposób mówienia, jej szlachetny ród, ale jeszcze szlachetniejsze obyczaje, jej głęboką pokorę, a przy tym nierównie wielkie dostojeństwo. Widzieliśmy jak wznosiła kościoły, jak jedne ołtarze ozdabiała, inne stawiała, z jakimi oznakami szacunku odnosiła się do książąt, do szlachty, do biskupów i kapłanów, z jaką łaskawością przyjmowała ubogich, jak życzliwie udzielała posłuchania, jak daleka była od wyszydzania kogoś, nie wszczynała kłótni ani nie była gadatliwa, nie unosiła się gniewem bez słusznej konieczności. Wiele z tego widzieliśmy, wiele poznaliśmy, lecz jeszcze więcej moglibyśmy zobaczyć, gdyby Bogu naszemu spodobało się utrzymać ją przy życiu.

I to właśnie niech będzie przyczyną waszej skargi żałosnej i zarazem kojącym lekarstwem, bo jeśli bolejemy za zmarłą o takich zaletach, to powinniśmy się raczej cieszyć, że ona, której sława nigdy nie zejdzie z ust ludzkich, taką właśnie była za życia. Zaiste głęboko wierzę, że już została wprowadzona do nieba, że jej imię wyryło się się $\mathrm{w}$ sercach wiernych i zostało zapisane w księdze żywota. Godną tego była i dlatego odeszła do Tego, który jest pełen majestatu. W jej przekonaniu królestwo ziemskie było wygnaniem, przeto z tej doliny łez wzbiła się ku niebu. Ona czyniła pokój i dlatego miejsce dla niej przygotowane wypełnia pokój, a mieszkanie jej na Syjonie [por. Ps. 75, 3]. Szukała czci Bożej i dlatego wieczne szczęście będzie nad jej głową [por. Iz. 35, 10]. Umiłowała Kościół walczący, ochraniając go jak tylko mogła, dlatego też, należy wierzyć, odeszła zeń do Kościoła triumfującego. Dobrymi uczynkami rozpalała serca żyjących według ducha i dlatego, jeśli nawet czegoś zaniedbała z racji ułomności natury ludzkiej, to przecież wspierana ich modlitwami już osiągnęła ostateczną szczęśliwość lub wkrótce ją osiągnie. Dobrocią i miłosierdziem szafowała wśród potrzebujących i dlatego pełen miłosierdzia Bóg, zanim nadeszła jej ostatnia chwila, podał jej pokarm życia, pokarm sakramentalny. On z wysokości swego tronu wspierał ją w cierpliwości, albowiem wiele znosiła w ukryciu, a jeżeli już nie była w stanie czemuś kresu położyć, cierpliwie to wytrzymywała. Lecz żeby jeszcze dokładniejszej próbie poddać jej cierpliwość, zesłały na nią niebiosa ciężkie choroby, przeróżne cierpienia i była poddawana doświadczeniom, jak złoto w tyglu. 
$J^{2} f .107$ va corona corruptibili | - immarcescibilem, pro mundano honore, qui ad instar umbrae vadit, honorem aeternum iam sibi dedit aut saltem interventu sanctae Dei Genitricis et omnium sanctorum ac spiritualiter viventium cito dabit. Non miremini igitur, quod ivit quae vocata est, quod

5 finivit quae mortua est, ut viveret.

Sed fortasse quis tacite secum disputat: - O Domine Deus! Lacrimas fundimus, processiones fecimus, vota emisimus in nomine Tuc, in honore sanctorum Tuorum. Quid fuit inpediens, quid removens, quod non sumus in nostris petitionibus exauditi? Quibus dico: Bene quaeritis

10 a Domino. Ipse enim est, ad quem pertinet huiuscemodi responsio. Qu: scit quare fecit. Humano tamen modo loquendo dico, fratres dilectissimi, quod Deus, qui bene omnia fecit et hoc bene fecit. Sed quia nescimus causas, lacrimamur, ingemiscimus, suspiramus. Poterant igitur causae istae occurrere, sed si occurrerunt, vel aliqua ipsarum, hoc ignoro. Quod

15 namque non sumus exauditi aut fuit ex eo, quod domina nostra tam Deo placuit, quod fuit magis dignum ipsam esse in refrigerio quam in aere pleno caligine, umbroso et condenso; aut ex eo, quia rapta est, ne malitia mutaret vitam eius; aut tam eminebat meritis, quod poterat dicere: Cupio dissolvi et esse in Christo; aut ex eo, quia non eramus $J^{2} f .107 \mathrm{rb}$ digni tanto thesauro. Fortasse | enim aliquos elevavit superbia, aliquos pravitas depressit usuraria, aliquos vexarunt pudenda adulteria, contra aliquos clamant viduae, plorant pupilli, suspirant ecclesiae; quosdam tantus fastus levavit in aerem, quod non nisi se curant, non nisi de se praedicant; quosdam alia et alia vitiorum genera fatigant ita, quasi qui-

25 libet in domo sua idola habeat, habeat monstra, quibus Deus irascitur. Aut forte ideo factum est ut probetur fides nostra, ut oriens et o c cidens et aliae plagae mundi cognoscant et videant fidem nostram, iuramenta nostra, quae servari est necesse? Aut ex eo, ut probetur patientia regis nostri? Ipse enim postquam creatorem agnovit, diversis

30 temptationibus est stimulatus generibus (?). Ipse enim temptatus est in matre, temptatus in fratribus, temptatus in bellis, temptatus in diversis contingentibus et novissime temptatus est generatione sua et consorte sua. Magna temptatio Ewstachii, magna temptatio regis nostri. Sed hoc fiat, ut tanto lucidior appareat, quanto temptationes Deo iuvante patien-

35 tius ferat. Quem confortare dignetur et conservare pro consolatione nostra, suae quoque consorti dare coronam regni caelestis, Deus per saecula benedictus. Amen.

33 S. Eustachius martyr, dux Romanus, obiit anno 118 p. Ch. n. 
Dlatego też Wasza Królewska Wysokość nie powinna się oddawać niepohamowanemu żalowi, ale przeciwnie, powinieneś radować się Królu, że tak niezwykłą miałeś małżonkę, a teraz - wielką przed Bogiem orędowniczkę królestwa. Również duchowieństwo i cały naród, przejęte żalem z powodu odejścia i braku jej osoby, niech nabiorą otuchy, wszak podążyła wspólną drogą, drogą uczęszczaną przez wszystkich bez wyjątku, drogą, którą trzeba przemierzyć, którą się idzie i dochodzi do Boga, ponieważ do oglądania Boga twarzą w twarz można dojść jedynie poprzez gorycz umierania. Ona poszła drogą, po jakiej Bóg polecił jej kroczyć, jako że On zsyła śmierć i daje życie, On wtrąca w grób i zeń wywodzi. Odeszła od nas i podążyła tam, gdzie rozciąga się nasze dziedzictwo. Zaiste żywię nadzieję, że Bóg, którego umiłowała, w którego wierzyła, którego czciła ponad wszystko, obdarzył ją królestwem wiecznym w miejsce doczesnego, zamiast kruchej korony - niezniszczalną, zamiast światowego rozgłosu, przemijającego na kształt cienia, dał jej cześć wiekuistą już teraz, albo też uczyni to niezwłocznie za wstawiennictwem świętej Bogarodzicielki, wszystkich świętych i według ducha żyjących. Nie dziwmy się przeto, że odeszła ta, która została wezwana, że osiągnęła kres swego życia ta, która umarła, aby żyć.

Ale może ktoś w skrytości serca tak sobie mówił: — Panie Boże! Płakaliśmy rzewnie, odprawialiśmy procesje i składaliśmy ofiary przegłagalne w imię Twoje i na cześć świętych Twoich. Cóż zatem stanęło na przeszkodzie, co oddaliło Cię od nas, że nie zostaliśmy wysłuchani $\mathrm{w}$ naszych prośbach? Odpowiadam im: Dobrze czynicie, pytając o to Pana. Do Niego bowiem tylko należy odpowiedź. On jeden wie dlaczego tak postąpił. Jednakże, bracia najmilsi, mówiąc całkiem zwyczajnie, jestem pewien, że Bóg uczyniwszy wszystko dobrze i w tym wypadku postąpił słusznie. My zaś, nie znając Jego powodów, szlochamy i zawodzimy żałośnie. Mogły zresztą one, lub przynajmniej jeden z nich, się pojawić, ale czy tak się zdarzyło, tego nie wiem. Bo to, że nie zostaliśmy wysłuchani mogło wynikać stąd, że Pani nasza tak bardzo została umiłowana przez Boga, iż godniej jej było zamieszkać w miejscu ochłody niż w mrocznej i dusznej atmosferze życia ziemskiego; albo też została tak nagle zabrana, aby żadna nieprawość nie odmieniła jej życia; mogło też być, że błyszczała takimi zasługami, iż mówiła sobie: Chciałabym już umrzeć i połączyć się z Chrystusem; albo też my nie byliśmy godni 
posiadania takiego skarbu. Jednych bowiem wynosiła pycha, innych poniżała lichwiarska przewrotność, jeszcze innych dręczyły bezwstydne cudzołóstwa, na jednych głośno użalają się wdowy, przez innych płaczą sieroty i skarżą się kościoły. Próżność niektórych do takich doszła rozmiarów, że troszczyli się tylko o siebie i tylko o sobie rozpowiadali naokoło; inni zaś dopuszczali się co raz to nowych występków tak, jakby każdy z nich czcił w swym domu bożków, lub jakieś potwory, przeciwko którym Bóg obraca swój gniew. Lecz może też być, że wszystko to stało się $\mathrm{w}$ celu wypróbowania naszej wiary, aby $\mathrm{na}$ W $\mathrm{schodzie}$ i $\mathrm{na}$ Zachodzie i we wszystkich częściach świata poznano i przekonano się, jaka jest ta nasza wiara i przysięgi, których trzeba dochować. Albo też może to cierpliwość naszego króla została wystawiona na próbę? On bowiem sam, gdy tylko przyjął wiarę w prawdziwego Stwórcę, znosił również różnego rodzaju doświadczenia życiowe. Spotykały go one już to ze strony matki, już to ze strony braci, albo przynosiły je wojny i inne rozmaite wypadki, ostatnie zaś zostało związane z przyszłością rodu i małżonka. Wielka próba dotknęła św. Eustachego, równie wielka naszego króla. Stało się to wszakże po to, aby zajaśniał on tym większym blaskiem, im cierpliwiej znosił z pomocą Bożą koleje swego losu. Niech błogosławiony na wieki Bóg łaskawie umocni go i nie opuszcza w pocieszeniu, a głowę jego małżonki otoczy koroną niebieskiego królestwa. 


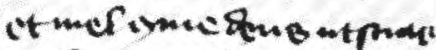
mysure malus elugtere

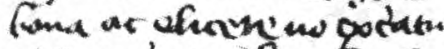

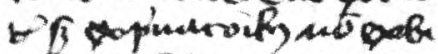
At Cistei tritif bomotite Ge

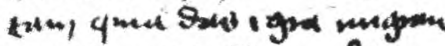

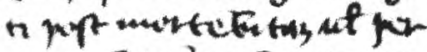

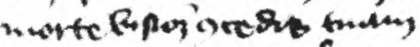

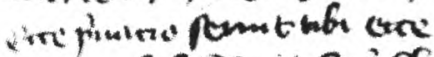
in. A ... fiti.n.s. pupated prulow

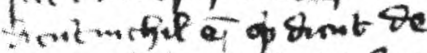

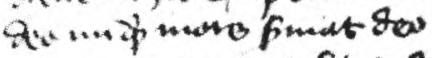

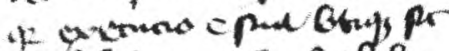
sinivint pindowe fo midhtion.

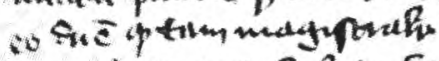
vter fintoncme fo of tor tor ate enqui non fit taiju

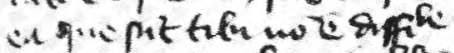

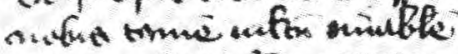
The nom toatites mit abx linte ymo gisechtrome oin wituo poterno yoma proisfungriter-termpr (it isgroup proms nomigna "ivi 7 yefr uns atiy trad

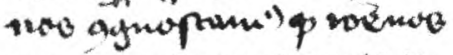
repe symit remone mob of

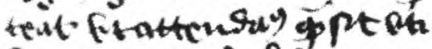

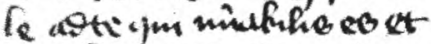

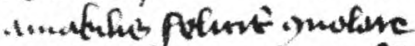
sines nobue oretre 7 th fortiming fal morty sten anetu nots momous 83 ines

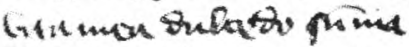

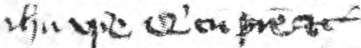

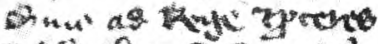

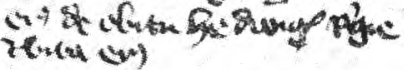

218. antitifint zorimfi

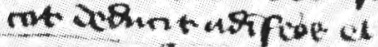

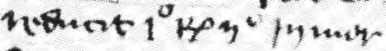
Gha Atus etmonimplent Forming wivetom, forit uph

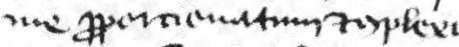
ountw..., firt-taken op pno

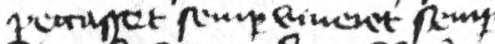

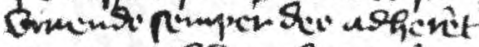

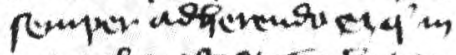

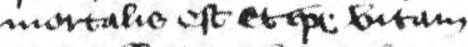

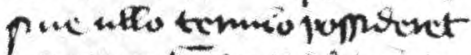

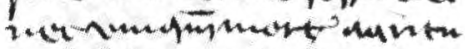

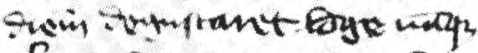

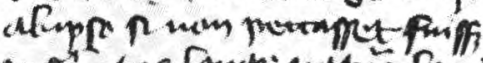

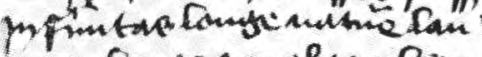

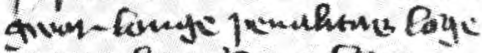
perme Roje timen Rigye ame

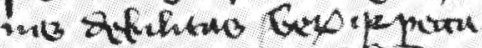

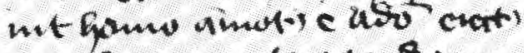

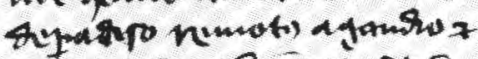

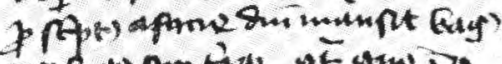

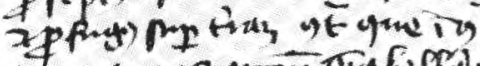

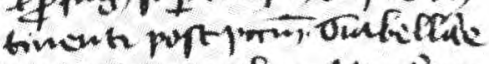
repentitan cition pares the

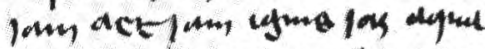

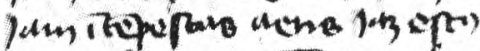
gam rafore gan for - pang tioner.

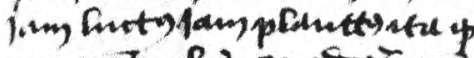
morvet alag questre y ym Goven uo imgunet fan torc Eitumetar Rejun a Reyc

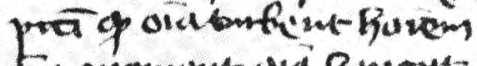
dia jumnet sia Rusent

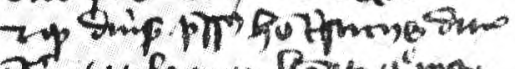

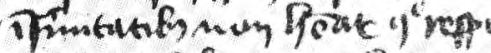

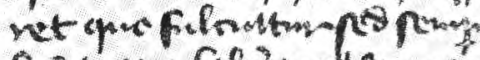

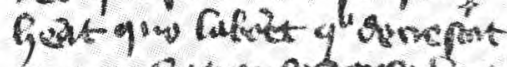

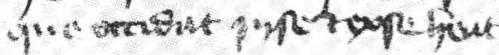





\section{POSEOWIE TEUMACZA}

Dnia 17 lipca roku 1399 umiera na Wawelu królowa Polski JADWIGA. Zapewne w dwa dni później, podczas uroczystości pogrzebowych, kazanie żałobne wygłosił Stanisław ze Skarbimierza, doktor dekretów, zaufany i bliski wspótpracownik biskupa krakowskiego Piotra Wysza ${ }^{1}$. Przypuszcza się, że tym kazaniem był właśnie tekst łaciński, którego edycję ogłaszamy powyżej po raz pierwszy, uzupetniajac ja nowym przekładem polskim.

Autograf Stanisława nie zachował się. Wydanie niniejsze zostało opracowane $w$ oparciu o kopię, przekazana $w$ rękopisie 191 (f. 105ra - 107rb) Biblioteki Jagiellońskiej. Kodeks ten wyszedt około r. 1415 ze skryptorni nieznanego kopisty ${ }^{2}$. Tak więc posiadana wersja kazania, jako jedyna, musiała nam wystarczyć zarówno do ustalenia jego formy łacińskiej, jak tė̇ dokonania przekładu polskiego, którego zreszta poprawność była całkowicie uzależniona od spełnienia poprzedniej czynności. Nie zrobił tego przed niespetna 150 laty $M$. Wiszniewski $i$ dlatego jego przekład obfituje nie tylko $w$ usterki stylistyczne, ale równie często wykazuje niezrozumienie oryginału, opuszczenia tekstu i inne dość istotne zmiany merytoryczne, tak przecież łatwe do popelnienia przy metodzie tłumaczenia wprost z rękopisu, zastosowanej właśnie przez tego, skąinąd zastużonego badacza polskiego piśmiennictwa ${ }^{3}$. W tym miejscu należy podkreślić jeszcze bezzasadność — powtarzanej zreszta później te$z y$ - Wiszniewskiego, jakoby Stanisław wyglosit to kazanie po polsku, ponieważ „Jagiełto po lacinie nie umiat”. Oba przypuszczenia nie zostały dotad potwierdzone żadnym świadectwem historycznym, a osobiście watpię czy takie kiedykolwiek się znajdzie. Czas i okoliczności, $w$ jakich sławny Stanisław ze Skarbimierza wygłaszal swoje płomienne kazanie, wykluczaja prawie na pewno możliwość przemawiania $w$ języku narodowym.

Wbrew pozorom forma językowa kazania nie należy do rzędu przeciętnej prozy kaznodziejskiej, co więcej, nie należy również do tego

1 Por. J. Wolny, Zagadnienie formacji duchowej królowej Jadwigi, „Notificationes e Curia Metropolitana Cracoviensi". R. 1974 s. 70.

2 Rękopis zawiera wyłącznie pisma Stanisława ze Skarbimierza. Znajdujemy tu jeszcze dwa inne teksty poświęcone Jadwidze: pierwszy to sławne Soliloqium de obitu Hedvigis reginae et vita eius (f. $97 \mathrm{rb}-\mathrm{vb}$ ), zapewne jeszcze z r. 1399; drugi natomiast, to Sermo latinus in exequiis dominae Hedvigis, reginae Poloniae (f. $352 \mathrm{rb}-356 \mathrm{ra}$ ), napisane przez Stanisława w rocznicę śmierci Jadwigi w r. 1401 (lub 1409), jak przypuszcza Z. Kozłowska-Budkowa (por. niżej). Datę rękopisu ustaliła Z. Kozłowska-Budkowa, Rękopisy kazania De bellis iustis [w:] L. Ehrlich, Polski wykład prawa wojny XV wieku. Warszawa 1955, 225; por. również: C. Zawodzińska, Pisma Stanisława ze Skarbimierza [...] „Roczniki Biblioteczne”. R. 4: 1960, $313 \mathrm{n}$.

${ }_{3}$ Por. M. Wiszniewski, Historia literatury polskiej, t. 5, Kraków 1843, 46-52. Tłumaczenie Wiszniewskiego przedrukowano kilkakrotnie, o czym por.: C. Zawodzińska, jw., 317. 
typu kazań, z jakimi oswoil nas Stanisław $w$ swej przeogromnej twórczości predykatorskiej. Fakt ten, obok następnych względów, stanowit dla tłumacza element dodatkowej trudności. W kompozycji tekstu Skarbimierczyk zaledwie wyodrębnit część ogólna teologicznq i aktualnq, dotyczaca bezpośrednio postaci Zmartej; ulubione wtręty biblijne ująt $w$ formie ogólnikowych sentencji; wszelakq uczoność ograniczył do minimum. Oczywiście respektuje on zasady ,artis praedicandi”, ale treśc przekazuje w swoistym porzadku stylistycznym. Natomiast czynnikiem dominującym jest spontaniczność jego wypowiedzi i autentyzm sytuacyjny treści. Mówca stara się wyrazić swój żal po zgonie umiłowanej przez naród Królowej, wczuwa się $w$ dramat serca tych, którzy go stuchaja, ale całe to spiętrzenie bezmiernego smutku $i$ boleści maluje $w$ słowach pozbawionych jakiejkolwiek przesady retorycznej i fatszywego patosu. Miejscami chciałoby się autora posq̨dzić wręcz o brak wrażliwości.

Sadzę, że ta prostota stylu została spowodowana również pośpiechem, $w$ jakim Stanisław pisat swoje kazanie. W toku jego lektury, a jeszcze bardziej analizy filologicznej, z nieodparta siłq utwierdza się $w$ czytelniku przekonanie, że Stanistaw po prostu nie miat czasu na stylistyczne polerowanie ani nawet na staranne opracowanie tekstu, pisanego przecież goraczkowo, $w$ atmosferze smutku i cięzkiego przygnębienia.

Widać więc $z$ jakim trudem panuje nad swoimi myślami, jak układa je $w$ jakiś merytorycznie logiczny ciag, ale to już było wszystko, na co go było stać $w$ tej dramatycznej chwili. Otóż M. Wiszniewski właśnie nie zrozumiat, że takie bez watpienia imponderabilia zaciażyly na formie kazania Skarbimierczyka i dlatego uznat je za ,pomnik [...] scholastycznєgo dzikiego stylu". Jest wszakże jeszcze jeden moment, który mógł zadecydować nad wyborem przez kaznodzieje stylu nie "dzikiego", lecz prostego $i$ bezpośredniego. Wielka kultura słowa, wiedza i wysokic umiejętności oratorskie pozwolity mu wygtosić krótka mowę nad trumna Królowej, ale mówiąc o Zmarłej w sposób całkiem zwyczajny, choé $w$ słowach płynacych $z$ głębi serca, potrafił $w$ nich przekazać jednocześnie nie tylko stosowne treści teologiczne, nie tylko wspaniale nakreślony obraz Jej duchowej i ludzkiej sylwetki, ale również wpleść jeszcze osobiste refleksje oraz elementy patriotyczne czy wręcz polityczne. To ciekawe zagadnienie struktury formalnej $i$ merytorycznej naszego kazania wymaga jednak szczegółowszej analizy na innym miejscu.

Chciałbym jednak zwrócić jeszcze uawgę na tło religijne kazania. Dla Stanisława Skarbimierza świętość zmarłej Królowej nie podlega żadnej watpliwości, choćby "nawet czegoś zaniedbała z racji ułomności natury ludzkiej". W tym przekonaniu umacnia go niezłomna wiara $w$ bezgraniczne miłosierdzie i sprawiedliwość Boża oraz świadomość niezwykłych zalet serca i umysłu młodej, pięknej Królowej. Ale cześć dl.u. 
Boga $i$ poszanowanie godności osoby ludzkiej, jak tė ochrona praura Bożego w Królestwie Polskim, to nie jedyne cechy jej osobowości. Byta przecież cudzoziemka na polskiej ziemi, a jednak uznała ja za swa ojczy$z$ nę, pokochała swój lud $i$ ze wszystkich sit zabiegała o umocnienie potẹgi Korony Polskiej. Dlatego właśnie powiada Stanisław, że w czasie śmiertelnej choroby Królowej modlono się, aby Bóg zachował przy życiu „te ozdobę Królestwa Polskiego”. Bo też był to prawdziwie „klejnot niezwykty".

$\mathrm{Na}$ koniec niech mi będzie wyrazić osobista radość z faktu ogłoszenia drukiem po tylu wiekach kazania, wygłoszonego ongiś nad trumna Królowej Jadwigi przez Stanisława ze Skarbimierza, pierwszego rektora odnowionego w rok później Uniwersytetu Krakowskiego. Wykonałem swci pracę z potrzeby serca, aby dać jeszcze jedno świadectwo, że „sława. Jej nigdy nie zejdzie $z$ ust ludzkich".

Pisałem w Krakowie we wrześniu 1974 roku.

ROMAN ZAWADZKI 
S E R M O

IN ANNIVERSARIO VENERANDAE HEDVIGIS, REGINAE POLONIAE, IPSA DIE BEATI ALEXII CONFESSORIS

Beati mortui, qui in Domino moriuntur.

Apc. 14 [13]

G f. 45 S f. 61 v

10

S f. 62 re

Carissimi! Valde utile est servis Dei saepius ad memoriam reducere sua novissima et extrema - Ecclesiastici VII ${ }^{\circ}$ [40]: Memorare novissima tua et in aeternum non peccabis; dirigit enim hominem inter prospera et adversa. Sicut aves cauda se regunt volando per aera et pisces natando in aqua, sic homo per mortis memoriam se regit in suis prosperis, ne elevetur per superbiam in adversis, ne demergatur per impatientiam. Quotiens igitur nostrorum carorum mortuorum memoriam agimus, totiens nostram mortem similiter recolamus.

Agimus igitur hodie memoriam venerandae HEDVIGIS, huius sacrae Coronae Poloniae reginae, quae tali die translata est ad Deum qua m pie speramus ia m regnare cum Christo.

Advertendum igitur, quod erat quaedam haeretica pravitas, scilicet saduceorum, qui non credebant resurrectionem mortuorum. Ex quorum errore fides in homine obumbratur, | spes confuditur et homo a caritate averititur. Ideo dicit apostolus (prima ad Cor. XV): Si resurrectio mortuorum non est, neque Christus resurrexit; si Christus non resurrexit, inanis est fides nostra. Similiter spes confunditur - prima ad Cor XV [19]: $\mathrm{Si}$ in hac vita tantum in Christo sperantes (Glossa: „Ut futuram re-

* Textum sermonis duo manuscripta saec. XV exarata in se continent: G - ms. 381 Archivi Archidioecesani Gnesnensis, nostrae editionis exemplar fundamentalis; $\mathrm{S}-\mathrm{ms}$. C Bibliothecae Seminarii Dioeceseos Sandomiriensis.

1-3 Sequitur sermo - - beati Allexii. Sequitur thema G; Sequitur sermo - beati Allexii confessoris S; Festum s. Alexii die 17 VII celebrabatur.

7 sepius ad $S$

10 sicut enim $S$

13 quociensque sine (?) igitur $S$

21-23 si resurrectio - - nostra, cf. 1 Cor. 15, 13-14: Si autem resurrectio mortuorum non est, neque Christus resurrexit. Si autem Christus non resurrexit, inanis est ergo praedicatio nostra, inanis est et fides vestra.

22 si Christus non resurrexit om. G.

24 ut $G$ ] si $S$ 
K A Z A N I E

W DNIU SWIETEGO ALEKSEGO WYZNAWCY W ROCZNICE SMIERCI CZCIGODNEJ JADWIGI, KROLLOWEJ POLSKI,

Błogosławieni zmarli, którzy umieraja w Panu.

Ap. 14,13

Najmilsi! Jest rzeczą wielce pożyteczną, aby słudzy Boży częściej pamiętali o swych sprawach najdalszych i ostatecznych, albowiem one są drogowskazem człowieka wśród pomyślności i nieszczęścia: Pamiętaj o swoich sprawach ostatecznych, a nie zgrzeszysz na wieki (Syr. 7, 40). Jak bowiem ptaki kierują ogonem swój lot w przestworzach, a ryby płynąc w wodzie, tak pamięć o zmarłych kieruje człowiekiem w pomyślności, by nie uniósł się pychą, natomiast w nieszczęściach — by nie pogrążył się $\mathrm{w}$ niecierpliwości. Ilekroć przeto wspominamy naszych drogich zmarłych, tylekroć z szacunkiem pomyślmy o własnej śmierci.

Otóż dziś obchodzimy pamiątkę śmierci czcigodnej JADWIGI, świętej Korony Polskiej królowej, w tym właśnie dniu przeniesionej do Pana, gdzie teraz, jak ufamy $w$ naszej pobożności, króluje już wraz z Chrystusem.

Zwróćmy wszakże uwagę, że wśród saduceuszy istniała przewrotna opinia, głosząca niewiarę w zmartwychwstanie umarłych. To błędne mniemanie zaciemnia w człowieku wiarę, rozprasza w nim nadzieję i odwraca go od miłości. Dlatego mówi apostoł: Jeśli nie ma zmartwychwstania umarłych, to i Chrystus nie zmartwychwstał; jeśli Chrystus nie zmartwychwstał, próżna jest nasza wiara (por. 1 Kor. 15, 13-14). Podobnie zanika nadzieja: Jeśli tylko za życia doczesnego w Chrystusie nadzieję pokładamy (Glossa: gdybyśmy nie wierzyli w zmartwychwstanie), 
surrectionem non speremus"), miserabiliores sumus omnibus hominibus. Propter quod dicitur [Apc. 14, 13]: Beati mortui, qui in Domino moriuntur.

Unde sciendum, 〈quod $\rangle$ secundum beatum Augustinum quintuplex

5 est mors. Prima mors est mors culpae, quando scilicet anima separatur a Deo. Et bene dicitur mors, nam dicit Augustinus: „Sicut corpus moritur recedente anima, a qua eius est vita, ita anima recedente a Deo, a quo eius est vita"; Ysaie LIX [2]: Iniquitates vestrae diviserunt inter vos et Deum vestrum; Sapientiae Io [3]: Perversae cogitationes separant a Deo;

10 prima ad Thi. VIo: Vidua vivens in deliciis corpore mortua est, scilicet spiritu; Ephe. II': Eratis sine Deo et sine Christo in hoc mundo. Hanc mortem, scilicet peccati, fugiebat haec veneranda HEDVIGIS et hoc propter quatuor. Primo propter Creatoris sui offensam, iuxta illud Ozee XII ${ }^{\circ}$ [14]: Ad iracundiam provocavit me Effraym in amaritudinibus suis;

15 id est - in peccatis. Secundo propter bonorum operum suorum in caritate factorum mortificationem - Ezechielis XVIII ${ }^{\circ}$ [24]: Si autem averteret se iustus a iustitia sua et fecerit iniquitatem secundum omnes abominationes, quas operari solet impius, $\langle-\longrightarrow\rangle$ omnes iustitiae, quas fecerat non recordabuntur. Tertio propter animae eius deturpationem - Thre-

20 norum primo [6]: Egressus est a filia Sion omnis decor eius; eiusdem III ${ }^{\circ}$ : Denigrata est super carbones facies eorum. Quarto propter hereditatis caelestis amissionem - Threnorum ultimo [2]: Hereditas nostra versa est ad alienos; quasi diceret: ex fragilitate commisit, mox per poenitentiam sanctam reformavit et per pia opera resuscitavit - Ezechielis

$25 \mathrm{XVIII}^{\circ}$ [21]: Si impius egerit poenitentiam de omnibus peccatis suis, quae $S f .62 \mathrm{rb}$ operatus est $\mid\langle-\longrightarrow$ vita vivet et non morietur.

Secunda mors est mors gehennae - Psalmus [33, 22]: Mors peccatorum pessima; ad Rom. VIII [13]: Si secundum carnem vixeritis, moriemini. Hanc mortem HEDVIGIS veneranda horrebat propter eius 30 horribilitatem. Est enim haec mors crudelissima. Primo propter Dei visionis - Isaye $\mathrm{XXVI}^{\circ}$ [10]: In terra sanctorum qui iniqua gessit, non

\footnotetext{
4 unde $S$ ] ubi $G$

7-8 ita anima - - est vita om. $S$

8 vos inter vos $S$.

10 vidua - mortua est, cf. 1 Tim 5, 6: nam quae (sc. vidua) in deliciis est vivens, mortua est.

11 Eratis - - mundo, cf. Eph 2, 12: quia eratis illo in tempore sine Christo, alienati a conversatione Israel et hospites testamentorum, promissionis spem non habentes et sine Deo in hoc mundo.

21 denigrata - - eorum, Thr 4, 8 .

23 q〈uasi $d\langle$ iceret $G$ ] quod $S$

31 qui om. $S$
} 
jesteśmy bardziej od wszystkich ludzi godni politowania (1 Kor. 15, 19). Dlatego powiedziano: Błogosławieni zmarli, którzy umierają w Panu (Ap. 14, 13).

Wiemy od św. Augustyna, że śmierć może być pięcioraka. Pierwszą śmierć powoduje grzech wówczas, kiedy dusza odchodzi od Boga. I słusznie mówi się wtedy o śmierci, albowiem powiada Augustyn: Podobnie jak umiera ciało z chwilą odejścia duszy, z której czerpie życie, tak i ona umiera $z$ chwilą odejścia od Boga, od którego ma życie; Wasze winy wykopały przepaść między wami a Bogiem waszym (por. Iz. 59, 2); Przcwrotne myśli oddzielają od Boga (Mdr. 1, 3); Wdowa żyjąca w rozpuście, za życia umarła (por. 1 Tym. 5, 6), mianowicie duchowo; Byliście bez Boga i bez Chrystusa na tym świecie (por. Ef. 2, 12). Tej śmierci tzn. przez grzech, czcigodna JADWIGA unikała z czterech powodów. Po pierwsze, aby nie obrazić swego Stwórcy, pamiętając o słowach Ozeåza $(12,14)$ : Do gniewu pobudził mnie Efraim przez swoje złośliwości tzn. grzechy. Po drugie, aby nie poszły na marne jej dobre uczynki speinione w miłości: A gdyby sprawiedliwy porzucił swą sprawiedliwośc i popełniał zło, naśladując wszystkie zbrodnie, którym się oddaje bezbożny $\langle-\rangle$, żaden z wykonanych czynów sprawiedliwych nie będzie mu poczytany (Ez. 18, 24). Po trzecie, by nie oszpecić swej duszy: Opuściło córę Syjonu całe jej dostojeństwo (Lam. 1, 6); Pociemniał ich wygląd na węgiel (tamże 4, 8). Po czwarte, aby nie utracić niebieskiego dziedzictwa: Dziedziczny nasz dział przypadł obcym (Lam. 5, 2) - jakby mówił: przez własną ułomność popełnił grzech, lecz niezwłocznie naprawil go świętą skruchą i przez pobożne uczynki zmartwychwstał; Jeśliby niezbożny żałował za wszystkie swoje grzechy, jakie popełnił $\langle-\rangle$, żyć będzie a nie umrze (Ez. 18, 21).

Druga śmierć jest na wieczne potępienie: Najgorsza śmierć jest grzeszników (Ps. 33, 22); Jeśli według ciała żyć będziecie, pomrzecie (Rz. 8, 13). Przed tą śmiercią, jakże straszną, drżała czcigodna JADWIGA. Ta śmierć bowiem jest najokrutniejsza po pierwsze dlatego, że traci się możliwość oglądania Boga: Nieprawość on czyni na ziemi prawych i nie zobaczy majestatu Boga (Iz. 26, 10) - po drugie z powodu jej srogości: 
videbit gloriam Dei. Secundo propter acerbitatem - Iob XXIII ${ }^{\circ}$ : Transibunt $\mathrm{ab}$ aquis nivium ad calorem nimium. Tertio propter omnis auxilii desperationem - Iob (!): In inferno nulla est redemptio; eiusdem $\mathrm{XX}^{\circ}$ : Velut somnum advolans non invenietur impius; Isaye VIII': Non poterit

5 impius de cetero ambulare de angustia sua. Quarto propter conscientiae remorsionem - Isaye ultimo [24]: Vermis eorum non morietur.

Tertia mors est, qua quis moritur peccato - ad Rom. XI ${ }^{\circ}$ [2]: Qui enim mortui sumus peccato, quomodo 〈adhuc〉 vivimus in illo? Hanc veneranda HEDVIGIS grate suscepit, dicens illud cum propheta [Rom.

10 8, 36]: Propter te mortificamur tota die.

Quarta mors - qua quis moritur mundo, sicut viri Deo dicati.

$G$ f. $45 v$ Hanc mortem veneranda HEDVIGIS multum dilexit. Existens enim tanta regina et tam magnifica mulier, mundum cum suis oblectamentis despexit, dicens ad Gal. VI ${ }^{\circ}$ [14]: Mihi mundus crucifixus est et ego mun-

15 do; ad Col. III $^{\circ}$ [3]: Mortui enim estis et vita abscondita est cum Christo in Deo.

Quinta mors est mors naturae - Sapientiae primo [13-16]: Deus mortem non fecit, $\langle-\rangle$ impii autem manibus et verbis accersierunt illam; Psalmus [88, 49]: Quis est homo, qui vivet et non videbit S f. 62 va mortem; II Reg. | XIIII ${ }^{\circ}$ [14]: Omnes morimur et quasi aqua dilabimur. Ista mors est homini inflicta propter peccatum Adae - Eccli XL ${ }^{\circ}$ [1]: Occupatio magna creata hominibus et iugum grave super filios Adae (Glossa: ,propter peccatum eius”). Haec mors est amara propter quatuor. Primo propter dolorem, quia in separatione animae a corpore maxi-

25 mus est dolor propter familiaritatem, quam habuerunt inter se. Secundo propter infernalis poenae acerbitatem. Tertio propter daemonum visionem. Quarto propter peccatorum confusionem. Ista enim quatuor vident animae, quando sunt in penultimo instanti vitae suae - Psalmus

1-2 transibunt - - nimium, cf. Iob 24, 19: Ad nimium calorem transeat ab aquis nivium.

4 velut - - impius, cf. Iob 20, 8: Velut somnium avolans non invenietur, transiet sicut visio nocturna.

4 impius $G$ ] nummus $S$

4-5 non poterit - - sua, cf. Is 8, 22: non poterit avolare de angustia sua.

6 morietur in eternum $S$

12 hec veneranda $S$

13 mulier om. $S$

21 Eccli $\mathrm{XLV}^{\circ} G$ 
Przyjdą z wód śnieżnych do wielkiego gorąca (por. Job 24, 19) - po trzecie $\mathrm{z}$ powodu zwątpienia we wszelką pomoc: $\mathrm{W}$ piekle nie ma żadnego ocalenia (Job!); Jak sen przeminął i nikt nie znajdzie niezbożnego (por. Job 20, 8); Zresztą niezbożny nie będzie mógł oddalić się od ucisku swego (por. Iz. 8, 22) - po czwarte, z powodu wyrzutów sumienia: Robak ich nie zginie (Iz. 66, 24).

Trzecia śmierć to ta, kiedy ktoś umiera dla grzechu: Jeżeli umarliśmy dla grzechu, jakże możemy jeszcze w nim prowadzić życie (Rz. 6, 2)? Czcigodna JADWIGA $z$ ochotą przyjęła tę śmierć, powtarzając za prorokiem: Dla ciebie to zabijają nas przez cały dzień (Rz. 8, 36).

Czwarta śmierć - kiedy ktoś umiera dla świata, jak to dzieje się z osobami poświęconymi Bogu. Czcigodna JADWIGA wielce umiłowała tę śmierć, będąc wszelako tak wielką królową i tak wspaniałą kobietą pogardziła światem wraz z jego uciechami, mówiąc: Dla mnie świat jest ukrzyżowany, a ja dla świata (Gal. 6, 14); Umarliście bowiem i życie wasze ukryte jest z Chrystusem w Bogu (Kol. 3, 3).

Piąta wreszcie to śmierć naturalna: Śmierci Bóg nie uczynił $\langle--\rangle$, bezbożni zaś ściągają ją na siebie słowem i czynem (Mdr. 1, 13-16); Czy jest ktoś, kto by żył a śmierci nie zaznał? (Ps. 88, 49); Wszyscy bowiem umrzemy z pewnością i jakby woda rozpłyniemy się (2 Krl. 14, 14). Podlega jej człowiek z powodu grzechu Adama: Wielka udręka stała się udziałem każdego człowieka i ciężkie jarzmo dla synów Adama (Syr. 40, 1); Glossa: z powodu jego grzechu. Gorycz tej śmierci wynika z czterech przyczyn. Pierwszą jest boleść, ponieważ oddzielenie duszy od ciała sprawia ogromny ból, gdyż między nimi utrzymywała się najintymniejsza łączność. Drugą jest srogość piekielnej kary. Trzecią oglądanie szatanów. Czwartą zawstydzenie grzeszników. Te bowiem cztery przyczyny 
[17,5]: Circumdederunt me dolores mortis; II Regnum XXII': Circumdederunt me contritiones mortis, torrentes bestiae conturbaverunt me. Et licet mors sit amara, veneranda HEDVIGIS grate ipsam suscepit, di-

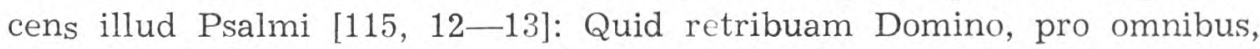
5 quae retribuit mihi? Calicem salutaris accipiam - id est mortem - et nomen invocabo.

Et nota, quod illorum, qui moriuntur hac morte, quidam intrant in infernum ut damnati; quidam in paradisum ut salvati, qui sufficientem poenitentiam fecerunt; quidam in purgatorium ut illi, qui in

10 hac vita non plene satisfecerunt pro peccatis suis. Illi clamant illud Iob XIX [21]: Miseremini mei, miseremini mei saltem vos amici mei. Sumitur autem amicus quatuor modis. Primo ille est amicus, qui alicui tenetur iure propinquitatis sicut filius patri, frater fratri etc. Et tales tenen$s f .62 v b$ tur subvenire suis mortuis - Augustinus, | De decem chordis: Si quis 15 propter filium pecuniam servabat, cum moritur, post illum partem suart mittat. Cur illam detinet et forte nulli eam amico relinquet, sed dicet: Servo fratribus eius, cum quibus dum vixit non erat divisus. O fides mortua, si in te est fides, filius tuus vivit nec discessit, sed processit. Qua fronte venturus es ad filium, cui praecedenti non mittis partem 20 suam? Secundo dicuntur amici aliqua fraternitate spirituali iuncti aut viri religiosi et ceteri - Psalmus [132, 1-2]: Ecce quam bonum et quam

1-2 circumdederunt - - conturbaverunt me, cf. 2 Reg. 22, 5: Quia circundederunt me contritiones mortis, torrentes Belial terruerunt me.

14-20 cf. Augustinus, Sermo IX ,De decem chordis" [PL 38, 90]: Quare non facit elemosinam? Quia servat filiis suis. Contigit, ut amittat unum; si propter filios servabat, mittat post illum partem suam. Quare illam tenet in saeculo et illum relinquit $a b$ animo? $\langle-\rightarrow$ Sed quid dicis? Servo fratribus ipsius. $\mathrm{Si}$ viveret ille, non erat cum suis fratribus divisurus? $\mathrm{O}$ fides mortua $\langle-\longrightarrow$. Si autem est in te fides, vivit filius tuus. Vivit prorsus; non decessit, sed praecessit. Qua fronte venturus es ad filium tuum, qui praecessit, cui praecedenti non mittis partem suam in caelum?

16 dicet in margine $S$ adscriptum, sed in textu dividet; om. $G$

17 quibus om. $S$

18 discessit $S$ ] discessisset $G$ 
stają przed oczyma dusz w ostatnich chwilach ich 〈ziemskiego〉 życia: Ogarnęły mnie cierpienia śmiertelne (Ps. 17, 5); Ogarnął mnie lęk śmiertelny i zatrwożyły mnie napaści szatana (por. $2 \mathrm{Krl} .22,5$ ). I choć śmierć jest [tak] gorzka, czcigodna JADWIGA oczekiwała jej z ochotą, wymawiając słowa psalmu: Czym ja się Panu wyplacę za wszystko co mi wyświadczył? Podniosę kielich zbawienia - to znaczy śmierci - i wezwę imienia Pańskiego (Ps. 115, 12-13).

Zauważ, że spośród tych, którzy tak umierali, jedni jako potępieni odchodzą do piekła; drudzy jako zbawieni - do raju, ponieważ dopełnili wystarczającej pokuty; inni - do czyśćca, ponieważ nie zdołali za swego życia całkowicie odpokutować za swoje grzechy. Ci ostatni wołają słowami Joba (19, 21): Zlitujcie sie, zlitujcie przynajmniej wy, przyjaciele moi. Przyjacielem zaś można być w czworaki sposób. Najpierw za przyjaciela uważa się kogoś z racji powinowactwa, jakim jest syn dla ojca, brat dla brata itp. I tacy są zobowiązani pomagać swoim zmarłym - Augustyn (O dziesięciu strunach): Jeżeli ktoś chował pieniądze m. in. dla syna, a ten umiera, to niech odeśle mu jego część. Dlaczegóż jednak zatrzymuje ją, a nie pozostawi jakiemuś przyjacielowi, lecz powie: Zachowuję ją dla jego braci, z którymi się za życia nie podzielił. O martwa wiaro, jeśli $w$ ogóle jest $w$ tobie wiara. Przecież syn Twój żyje i nie odszedł z tego świata, a tylko poszedł przodem. Z jakim czołem masz zamiar pójść do swego syna, który cię wyprzedził, jeśli mu nie oddasz należnej części? Następnie można też mówić o przyjaciołach złączonych braterstwem duchowym, jak bracia zakonni i inni: Oto jak 
iucundum habitare fratres in unum! Sicut unguentum in capite, quod descendi et cetera per unctionem, quae fuit in capite et descendit in oram vestimenti. Intelligitur, quod debent sibi communicare unctionem meritorum, per quam debent mutuo se iuvare. Tertio amici sunt iure

5 amicitiae spiritualis, ut quando ex dilectione unius promittit pro alio orare et econverso. Tales ut frequenter fideliores sunt aliis - Proverbiorum XVIII ${ }^{\circ}$ [24]: Vir amicabilis ad societatem, magis amicus erit quam frater; eiusdem XVII ${ }^{\circ}$ [17]: Omni tempore dilligit qui amicus est. Sed de falsis amicis dicitur Job VI' [14]: Qui tollit ab amico suo misericordiam,

10 timorem Domini derelinquit; Proverbiorum XIX [7]: Et fratres hominis pauperis oderunt illum, insuper et amici procul recesserunt ab eo. Quarto dicuntur amici ratione alicuius beneficii recepti, ut elemosinarum etc. Et tales omnino tenentur ad subveniendum suis mortuis - Proverbiorum $\mathrm{VI}^{\circ}$ | [1-4]: Si spoponderis pro amico tuo, defixisti apud extraneum ma15 num tuam, $\langle-\rightarrow\rangle$ discurre, festina, suscita amicum tuum, ne dederis somnum oculis tuis, nec dormitent palpebrae tuae.

Et quia veneranda HEDVIGIS fuit propinqua nostra, soror nostra, confratra nostra, benefactrix nostra, ideo tenentur pro ea orare, ut si, quod absit, prout speramus, adhuc aliquid in purgatorio pateretur, oratio-

20 nibus nostris liberaretur certe benefactrix maxima huius totius Coronae Regni Poloniae. Ipsa fuit causa erectionis et fundationis huius sanctae Universitatis Cracoviensis nec maius bonum facere potuit. Lumen enim erexit, quo totum regnum, immo tota christianitas illustratur, docetur et ad virtutes inducitur. Quot doctores, quot magistri, quot viri litterati,

G f. 46 homines religiosi et sancti iam de hac / Universitate creverunt et dante Domino in futuro crescent - quis enarrare poterit? Ipsa enim est omnium bonorum particeps, quaecumque per illos bona aguntur, quae non sunt modica, ut videmus. Ipsa pro decore huius ecclesiae Cracoviensis et honore Dei psalterium nocte dieque in eadem legi procuravit, quod 30 hucusque. temporibus nostris agitur.

1-3 sicut - vestimenti, cf. Ps 132, 2: Sicut unguentum in capite, quod descendit in barbam, barbam Aaron, quod descendit in oram vestimenti eius. descendit om. G; in horam $S$

7 ad sobrietatem et societatem $S$

14 pro om. G; defixeristi $S$

19 prout non est $G$

21 regni om. $G$

26 enim $G$ ] vero $S$

29 non sunt 
dobrze i jak miło braciom zamieszkać społem; jak olejek na głowie, który spływa po namaszczeniu, jakie było na głowie i ścieka na dekolt (por. Ps. 132, 1-2). Znaczy to, że powinni przekazywać sobie balsam dobrych uczynków i nimi się krzepić. Z kolei węzeł przyjaźni duchowej łączy przyjaciół wówczas, kiedy kierując się wzajemną miłością, jeden obiecuje modlić się za drugiego. Jakże często tacy są wierniejsi od innych: Człowiek przyjazny $\mathrm{w}$ towarzystwie będzie wierniejszym przyjacielem od brata (Prz. 18, 24); Przyjaciół kocha w każdym czasie (tamże 17, 17). Lecz o fałszywych przyjaciołach mówi Job $(6,14)$ : Kto przyjacielowi litości odmawia, ten gardzi bojaźnią Bożą; Biedaka wszyscy bracia nie lubią, tym bardziej najbliżsi stronią od niego (Prz. 19, 7). Wreszcie przyjaciółmi są ci, od których doznajemy jakichś dobrodziejstw, np. w postaci jałmużny itp. Tacy [obdarowani] mają szczególny obowiązek pomagać swoim zmarłym: Gdy za bliźniego ręczyłeś, gdy za obcego rękę podałeś $\langle-\longrightarrow$ idź, biegnij i na bliźniego nalegaj, oczom swym nie daj się zamknąć, powiekom nie dozwól odpocząć (Prz. 6, 1-4).

Skoro zatem czcigodna JADWIGA była dla nas kimś bardzo bliskim, niemal siostrą, współtowarzyszką, była naszą dobrodziejką, przeto mamy obowiązek kierować za nią nasze modlitwy, aby one uwolniły tę największą dobrodziejkę całego Królestwa Polskiego od najmniejszego cierpienia w czyśćcu, które, jak się spodziewamy, ominie ją całkowicie. Bo to ona była przyczyną założenia i ufundowania świętego Uniwersytetu Krakowskiego i zaiste niczego wspanialszego nie mogła uczynić. Wysoko bowiem podniosła światło nauki, napełniając swym blaskiem całe królestwo i w ogóle całe chrześcijaństwo prowadząc ku cnotom. Któż potrafi wyliczyć ilu doktorów, ilu magistrów, pisarzy, osób duchownych i świętych wydał ten Uniwersytet, a ilu jeszcze, z łaski Boga, wyda w przyszłości? Ona zaś sama jest po części sprawczynią tych wszystkich dobrodziejstw, jakie za sprawą owych [uczonych] dzieją się i, jak widzimy, nie są zwyczajne. Również ona na chlubę krakowskiego kościoła i dla chwały Bożej poleciła, aby dniem i nocą odmawiano psałterz, który to zwyczaj i dzisiaj się utrzymuje. 
Propter quod morte ipsius dolere non debemus, immo gaudere et consolari. Et hoc propter plura.

Primo propter moriendi necessitatem. Unde Augustinus in libro De cura pro mortuis narrat, quia fuit quidam princeps paganus unicum

5 habens filium. Qui cum diis suis errore gentili sacrificaret, nuntiatum sf.63 est ei, quia filius suus obiisset, non reliquit sacra nec | lacrimatus est, sed ait: Sepeliatur. Memini me illum genuisse mortalem.

S e c und o propter revocandi impossibilitatem (II Regum XIIo). Cum David pro infante infirmo se affligebat, in terra sedebat, ieiunabat et

10 orabat, ut sibi puer restitueretur. Postquam autem cognovit ipsum esse defunctum, de terra surrexit, faciem lavit atque comedit, dicens: Ego ibo magis ad eum, quam ipse ad me. Item dcbernus consolari propter Dei beneplacitum et voluntatem, quia sic fuit voluntas Dei. Unde narrat Augusinus (De civitate Dei), quia Marcus, christianissimus Romanus, ar-

15 mato equo in obruptum terrae hiatum praecipitem se dedit, ut misevant dii, ut illic mitterent Romani optimum, quem haberent. Jeronimus dicit in epistola ad Cyrasium: Quid faceremus, si mori tamen praeciperet Deus? Voluntas eius utique sufficeret ad consolationem, cui nullum praeponere iubemur affectum. Item debemus consolari propter miseriae mundi huius evasionem - Ambrosius in libro De bono mortis: Si plena oneris est vita, utique finis bonus eius est.. Item propter debiti solutionem. Unde narrat Augustinus: „Cum quidam episcopus infirmaretur et sic diceretur, quod ipsum Dominus liberaret, quia utilis multum esset, conversus ad Dominum dixit: Si umquam bene, quare non hodie, id est cur ulterius differo?" Similiter de beato | Ambrosio narrat Paulus, quia

3-7 cf. Augustinus, De cura pro mortuis [PL 40, 591-610]. Ibi illam fabulam, quae ad Anaxagoram ut videtur pertinet, in Augustini libro non inveni. 5 gentilium $S$

11-12 ego - - me, cf. 2 Reg 12, 23: Ego vadam magis ad eum, ille vero non revertitur ad me.

14 Marcus christianissimus G] Tyrinus $S$

15 ut miserant $G$ ] quia miserunt $S$

17-19 cf. ps-Hieronimus, Epistula XL ad Tyrasium super morte filiae suae [PL 30, 287]: Quid feceremus si mori tantummodo sine resurrectione praeciperet Deus? Voluntas eius utique sola sufficeret ad solatium, cui nullum praeponere iubemur affectum.

20 huius om. $G$

20-21 cf. Ambrosius, De bono mortis [PL 14, 569]: Si plena oneris est vita, utique finis eius allevamentum est.

24 nunquam $G$ ] inquam $S$ 
A zatem jej śmierć nie powinna przejmować nas boleścią, ale napełniać radością i pociechą. Bo też jest ku temu wiele powodów.

Najpierw dlatego, że śmierć jest koniecznością. Augustyn opowiada w swoim dziele ,O trosce o zmarłych', że był pewien książę pogański, mający jedynego syna. Kiedy podczas rytualnego składania rodzimych ofiar swoim bogom doniesiono mu, że zmarł jego syn, nie poniechał czynności sakralnych i nie zalał się łzami, a tylko powiedział: Niech będzie pogrzebany. Pamiętam, że zrodziłem go śmiertelnym. Po wtóre, nie ma żadnej możliwości powrotu (por. $2 \mathrm{Krl}$. 12, 15-23). Oto Dawid podczas choroby syna zadawał sobie umartwienia, siadywał na ziemi, pościł i modlił się, aby [Bóg] przywrócił chłopcu zdrowie. Kiedy zaś dowiedział się, że ten umarł, podniósł się z ziemi, obmył twarz i posilił się, a potem powiedział: Szybciej ja zajdę do niego niźli on do mnie. Podobnie $w$ łaskawości i woli Bożej winniśmy szukać pocieszenia, ponieważ z jego woli [przychodzi śmierć]. Opowiada Augustyn (O państwie Bożym), że Marek, prawdziwy chrześcijanin rzymski, okulbaczywszy konia rzucił się wraz z rim do głębokiej przepaści, gdyż było wolą bogów, aby tam Rzymianie strącili najlepszego ze swoich. Hieronim w liście do Cyrazjusza tak mówi: Cóż poczniemy, güy Bóg poleci nam jednak umrzeć? Wola jego jest wystarczającą pociechą i nie chciejmy przedkładać nad nią innego uczucia. Powinniśmy również szukać pocieszenia z uwagi na możliwość uwolnienia się od nieszczęść doczesnych. Ambroży w dziele ,O dobru śmierci' powiada: Jeśli życie jest wypełnione trudami, jego kres zawsze jest dobry. [Pociechą naszą] jest również rękojmia zbawienia. Podaje znowu Augustyn: Mówią, że pewien biskup, kiedy zostal przez Pana uwolniony od choroby, ponieważ był bardzo potrzebny, zwróciwszy się do Pana powiedział: Jeśli kiedyś będzie właściwa pora [śmierci], czemu nie dzisiaj, tzn. po co ją odwlekam? Natomiast Paweł opowiada 
cum in extermis esset et rogaret, ut prolongationem vitae sibi a Domino obtineret, sic ait: „Non vixi, ut me pudeat inter vos vivere, nec mori timeo, quoniam bonum Dominum habemus". Item debemus consolari propter exilii plenam absolutionem - Chrisostomus, Super Matthaeum:

5 Mundus iste domus est corporis, caelum autem est domus animae. Et sic anima hic est peregrina, caro autem domestica. In caelo vero anima erat domestica, caro autem peregrina. Unaquaeque autem res in sua patria fortior est et amplius duratur. Item debemus consolari propter vitae aeternae adoptionem. Unde narrat Augustinus (De civitate Dei), quod

10 Theobratus philosophus lecto Platonis libro, ubi de immortalitate animae disputat, se praecipitem dedit de muro atque ita, ut de hac vita migraret ad eam, quam credidit esse meliorem. Et Tullius dixit: O praeclarum diem, cum ad illum divinum animorum consultum securus proficiscar, cum ex hac turba calumniae discedam! Proficiscar enim ad viros sapien-

15 tes et ad Cathonem meum praecipue amicum, quo nemo vir melior natus est, nemo pietate praestantior.

$s f .63 v b \quad$ Si ergo pagani gaudebant, quanto plus nos christiani, | qui be atit udin em in anima et corpore sumus adepturi, prout pie speramus, quia haec veneranda HEDVIGIS est a depta, ubi iam visus ipsius 20 pascitur et delectatur - Eccli IIII': Gratiam et speciem desideravit oculus, auditus suavissima melodia dulcoratur; Canticorum II ${ }^{\circ}$ [14]: Sonet vox tua in auribus meis, vox enim tua dulcis; Isaye LI $^{\circ}$ [3]: Gaudium et laetitia invenietur in ea, gratiarum actio et vox laudis. Item delectatur

rogaretur $S$

3 item $G$ ] ideo $S$

9-12 cf. Augustinus, De civitate Dei [PL 41, 36]: Cleombrotus philosophus $\langle-\rightarrow$ lecto Platonis libro, ubi de immortalitate animae disputat (-vit $S$ ) se praecipitem dedisse de muro atque ita ex hac vita migrasse ad eam, quae credidit esse meliorem.

12-16 cf. Cicero, Cato maior de senectute [84]: O praeclarum diem, cum in illud divinum animorum concilium coetumque proficiscar cumque ex hac turba et conluvione discedam! Proficiscar enim non ad eos solum viros, de quibus ante dixi, verum etiam ad Catonem meum, quo nemo vir melior natus est, nemo pietate praestantior.

20-21 gratiam - - dulcoratur, cf. Eccli 40, 21-22: Tibiae psalterium suavem faciunt melodiam $\langle-\longrightarrow\rangle$. Gratiam et speciam desiderabit oculus tuus. sonat $G S$ 
o św. Ambrożym, że ten, kiedy był już u kresu swego życia i prosił Pana o jego przedłużenie, to tak powiedział: Nie wstydzę się swego życia wśród was i nie obawiam się umierać, ponieważ mamy dobrego Pana. Powinniśmy też znajdować pociechę w możliwości całkowitego zakończenia wygnania. Chryzostom w komentarzu do Ewangelii według św. Mateusza mówi: Ten świat jest domem ciała, niebo zaś domem duszy. I tak dusza jest tu [na ziemi] obcym przybyszem, ciało zaś domownikiem. W niebie zaś dusza była domownikiem, a ciało przybyszem. Każda przeto rzecz staje się trwalsza $\mathrm{w}$ swoim rodzimym środowisku i przedłuża swą egzystencję. Również pociechą naszą jest osiągnięcie życia wiecznego. Opowiada Augustyn (O państwie Bożym), że filozof Kleombrotus przeczytawszy dzieło Platona, w który autor rozprawia o nieśmiertelności duszy, rzucił się na głowę z muru, aby w ten sposób przenieść się do życia, uważanego za lepsze. A Cicero powiedział: O wspaniały dniu, w którym bezpiecznie podążę na ową boską naradę dusz, gdy opuszczę to zbiorowisko oszczerstw. Udam się do mędrców i do Katona, mego szczególnego przyjaciela, od którego nikt nie urodził się lepszy, nikt bardziej wyróżniający się pobożnością.

Jeżeli zatem śmierć napełniała nawet pogan radością, to o ileż bardziej nas chrześcijan, zamierzających osiągnąc szczęśliwość duszy i ciała tak, jak - żywimy zbożną nadzieję - osiągnęła ją już czcigodna JADWIGA tam, gdzie oczy jej sycą się i radują [widokiem Boga]: Wdzięk i piękność pociągają oko, słuch pieści najłagodniejsza melodia (por. Syr. 40, 21-22); Zadźwięczy głos twój w uszach moich, słodki bowiem jest twój głos (Pnp. 2, 14); Zapanuje w nim radość i wesele, pienia dziękczynne przy dźwięku muzyki (Iz. 51,3). Tam rozkoszuje się [Jej] powo- 
olfactus ex odore purissimi corporis Christi - Canticorum Io [3]: Curremus in odorem unguentorum tuorum; Eccli XXIII ${ }^{\circ}$ [21]: Quasi balsamum non mixtum odor meus. Item delectatur gustus in plena Dei delectatione, ipsa scilicet deitate - Job XXXI' [31]: Quis det de carnibus

5 eius, ut saturemur? Ex anima Christi tam dulcissima - Eccli XXIIII [27]: Spiritus meus super mel dulcis, tactus delectatur in osculando; Canticorum VIII ${ }^{\circ}$ [1]: Quis mihi det te fratrem meum, sugentem ubera matris meae, ut inveniam te foris et deosculer te. Item in amplexando -

G f. $46 v$ Canticorum II ${ }^{\circ}$ [6]: Laeva eius sub capite meo et dextera / illius am-

10 plexabitur me. Anima vero eius iam fruitur illa beata delectatione, ut pie speramus, quam nec oculus vidit, nec auris audivit, nec in cor hominis ascendit [1 Cor. 2, 9], ad quam nos una cum veneranda HEDVIGE perducat Deus gloriosus, in saecula benedictus.

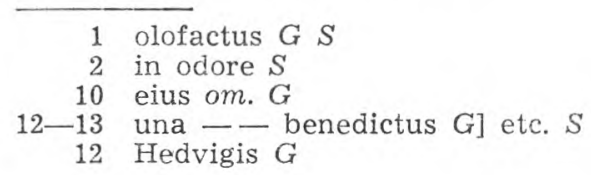

NOTA EDYTORSKA

Anonimowe kazanie na rocznicę śmierci królowej Jadwigi występuje w kolekcji kazań de sanctis, zachowanej w rękopisie S (f. $51-168 \mathrm{v})$ i G (f. $1-60){ }^{1}$.

Biorąc pod uwagę fakt, że w zbiorze tym są kazania o świętych polskich, a mianowicie: o św. Stanisławie (dwa), św. Wojciechu, św. Wacławie, św. Jadwidze śląskiej, należy przypuszczać, że zostały one napisane przez Polaka. Dodatkowe przesłanki czerpiemy w tym względzie z kazania na uroczystość św. Piotra i Pawła, których autor nazywa patronami kościoła poznańskiego. $\mathrm{Na}$ tej podstawie można by wnosić, że kazanie to było głoszone w katedrze poznańskiej. Natomiast kazania na uroczystość św. Stanisława (w maju i translacja na jesieni) oraz św. Wacława wskazują, że kolekcja ta musiara powstać w środowisku krakowskim. Ponadto w rękopisie sandomierskim jest jeszcze kazanie na uroczystość św. Zofii, bardzo izadko występujące $\mathrm{w}$ kolekcjach de sanctis ${ }^{2}$.

Możemy więc przyjąć, że od tego samego autora pochodzi kazanie na rocznicę śmierci królowej Jadwigi. Nie jest to kazanie uniwersyteckie, gdyż kaznodzieja nie rozpoczyna od zwyczajowej formułki: Venerandi patres, doctores et magistri. Stąd wniosek, że, jak pozostałe kazania tej kolekcji, i to było przeznaczone dla kleru katedralnego. Terminus post quem kazania o królowej Jadwidze możemy określić na podstawie braku wzmianki o procesie kanonizacyjnym Jadwigi, wszczętym, jak wiadomo, w r. 1426. Już na podstawie powyższych uwag należy przyjąć, że autor tych kazań działał przed r. 1426, jako kaznodzieja w Krakowie i Poznaniu. Z tego okresu znamy dwóch takich kaznodziejów, których można by uważać za autorów

1 Informacje o rękopisie gnieźnieńskim przesłał mi ks. kan. W. Zientarski, za co składam mu na tym miejscu serdeczne podziękowanie.

2 S, f. 152r: Zophia, Sapientia vocavit ancillas suas ad arcem, Prov. [9, 3]. Carissimi, prout dicit beatus Bernardus - - 
nienie zapachem najczystszego ciała Chrystusa: Pobiegnijmy za wonią twych pachnideł (Pnp. 1, 3); Jako balsam najczystszy woń moja (Syr. 24, 21). Tam rozkoszuje się jej smak w pełnej radości Bożej, tzn. w samej boskości: Któż udzieli nam jego ciała, abyśmy się nasycili? (Job 31, 31) — w najsłodszej duszy Chrystusa: Duch mój słodszy od miodu, dotyk raduje się w pocałunkach (por. Syr. 24, 27); O gdybyś był moim bratem, który ssał pierś mojej matki. Spotkawszy cię na ulicy ucałowałabym cię (Pnp. 8, 1) - w uściskach: Lewa jego ręka pod moją głową, a prawa obejmuje mnie (Pnp. 2, 6). Dusza zaś jej, jak z nabożnością żywimy nadzieję, rozkoszuje się już ową błogosławioną szczęśliwością, której ani oko nie widziało, ani ucho nie słyszało, ani serce człowieka nie przeczuwało (1 Kor. 2, 9), a do której niech zawiedzie nas wraz $\mathrm{z}$ czcigodną JADWIGA pełen chwały i na wieki błogosławiony Bóg.

wymienionej kolekcji. Jest to Mikołaj z Kozłowa i Mikołaj z Błonia. Mikołaj z Kozłowa, profesor teologii na Uniwersytecie Krakowskim i kanonik poznański, przebywał w Poznaniu w latach 1424-1426 ${ }^{3}$. W Krakowie należał do wybitniejszych mówców. Sciślejsze zaś związki łączyły z Poznaniem i Krakowem Mikołaja z Błoriia. Ten doktor dekretów ${ }^{4}$ był w latach 1422-1427 kapelanem i kaznodzieją królewskim. Na dworze krakowskim poznał Stanisława Ciołka, podkanclerzego królewskiego, który zamianowany biskupem poznańskim zabrał Mikołaja do Poznania w r. 1428 jako swego kapelana ${ }^{5}$. Wiemy, że w Krakowie wygłosił Mikołaj z Błonia jakieś kazanie o św. Zofii podczas uroczystości zaślubin królowej Zofii z Jagiełłą wv dniu 7 lutego 1422 roku ${ }^{6}$.

Mikołaj z Blonia opracował znane od dawna kolekcje kazań de tempore i de sanctis. Jest więc rzeczą wielce prawdopodobną, że kolekcja o świętych polskich, choć anonimowa, uzupelnia merytorycznie poprzednie. W oparciu o przedstawione argumenty można zatem uważać Mikołaja z Błonia również za autora kazania w rocznicę śmierci królowej Jadwigi ?.

3 Por. M. Markowski, Mikołaj z Kozłowa. „Materiały i Studia Zakładu Historii Filozofii Starożytnej i Średniowiecznej". T. 5: 1965 s. 80-88.

4 Mikołaj z Błonia studiował w Krakowie i tu uzyskał stopnie naukowe: w r. 1421 magistra artium, zaś przed r. 1427 otrzymuje tytul doktora dekretów.

5 Por. B. Ulanowski, Mikotaj z Btonia - kanonista polski $z$ pierwszej połowy $X V$ wieku. ,Rozprawy i sprawozdania z posiedzeń Wydziału Historyczno-Filozoficznego Akademii Umiejętności". T. 23: 1888 s. 20-22.

${ }_{6}$ Na temat wzmianki w kazaniu o ucztach królewskich por.: J. Wolny, Materiały do historii wagantów w Polsce średniowiecznej. „Biuletyn Biblioteki Jagiellońskiej". R. 19: 1969 nr 1/2 s. 81 n.

$7 \mathrm{Na}$ autorstwo Mikołaja z Błonia wskazałem w artykule: Królowa Jadwiga $w$ oczach wspótczesnych. "Tygodnik Powszechny”. R. 23: $1969 \mathrm{nr} 30$ (1070) s. 3. 


\title{
III
}

[FR A N ISCI de BREGA]

\author{
SERMO \\ IN EXEQUIIS DOMINAE HEDVIGIS, REGINAE POLONIAE]
}

wf.124 Ad honorem Dei omnipotentis et praesentis congregationis propono

5 ista verba: Celebravit exequias universus Iuda. Sic scribitur de rege Ezechia $2^{i}$ Paralipomenon $32^{\circ}$ [33] et videntur verba convenire praesenti negotio. Ex quo universus populus Iudaicus motus fuit ad celebrandum exequias praemisso regi propter certa beneficia eidem populo singulariter exhibita, quomodo non ratione instigante faceremus exequias huic se-

10 renissimae principi ac dominae, dominae HEDWIGI, matri nostrae bonae memoriae, olim reginae Poloniae, cuius anniversarius ad praesens iuxta exigentiam temporis recolitur, praesertim cum eadem Domina secundum suam magnificentiam istius Ecclesiae exstitit singularis benefactrix et promotrix et nostrae Universitatis instigatrix et fundatrix. Ex cuius pro-

15 motionibus, provisionibus et ordinationibus multi venerunt ad statum honorificum, ad quem alias non venissent et taliter qualiter stetissent, praecipue cum ex universitate nostra varia dependeant beneficia non solum quoad incolas regni, sed etiam quoad ext $\langle\mathrm{e}\rangle$ ras nationes iuxta contentas. Cum occasione eiusdem studii qui alias mansisset laicus, indoctus

20 et idiota, dum bene utatur praemisso studio, nonnumquam efficitur maturus in moribus, clarus in virtutibus, in multis rebus expertus et in variis scientiis illustratus et interdum sicut propheta reputatus. Et qui per se stetisset in caecitatis errore, aliquando, Domino auxiliante, tantum erigitur in veritatis cognitione, ut tribuitur aliis pro informatore, et sae-

- Textum sermonis anno 1426 scripti ms. W (f. 124-129r) Bibliothecae Universitatis Wratislaviensis praebet. Verisimile est illum textum autographum Francisci de Brega esse, sed res parum perspicua nobis videtur. Fortasse marginalia et interlinearia, quae litteris obliquis in textu edito distinximus, ipse auctor inscripserat, ut narrationem suam lucidiorem correctioremque redderet. Siglo del. (= deletum, deleta) in apparatu critico verba ab auctore vel librario expuncta instruxi. Ad rem cf. M. Kowalczyk, op. cit., p. 122.

1-3 Textus sine nomine auctoris et inscriptione in ms. exstat.

7 universos populos Iudaicos sic ms. (item infra p. 54, 15).

17 presertim del. sub praecipue.

22 sep del. post interdum.

23 erigitur del. post aliquando. 


\section{KAZANIE \\ W ROCZNICE ŚMIERCI JADWIGI, KRÓLOWEJ POLSKI}

Na chwałę wszechmogącego Boga i zgromadzonych tu osób rozpoczynam w te słowa: Cały Juda odprawit uroczystości żałobne. Tak jest zapisane o królu Ezechiaszu (2 Krn. 32, 33) i słowa te wydają się być trafnie wybrane na dzisiejszą uroczystość. Jeżeli cały lud żydowski dał się nakłonić do odprawienia uroczystości żałobnych za wspomnianego króla ze względu na pewne dobrodziejstwa, w szczególny sposób wyświadczone temuż ludowi, dlaczego my, kierując się podobną pobudką, nie mielibyśmy odprawić egzekwii za tę najjaśniejszą księżnę i panią JADWIGE, świętej pamięci matkę naszą, niegdyś królowę polską, której rocznicę śmierci, przypadającą w dniu dzisiejszym, właśnie obchodzimy, zwłaszcza że Pani ta przez swą wspaniałomyślność stała się niezwykłą dobrodziejką i opiekunką tego Kościoła oraz inicjatorką i fundatorką naszego Uniwersytetu. To dzięki jej poparciu, uposażeniom i zarządzeniom wielu osiągnęło takie godności, do jakich by nigdy w inny sposób nie doszli i nie staliby się tak znakomici, gdyż od naszego Uniwersytetu uzależnione są różnego rodzaju beneficja, dostępne nie tylko dla mieszkańców królestwa, lecz także dla narodów ościennych. Dzięki tej uczelni każdy, kto w innych okolicznościach pozostałby niewykształconym prostakiem i głupcem, nierzadko, o ile w sposób właściwy z niej korzystał, staje się dojrzałym w obyczajach, błyszczy cnotami, a osiągnąwszy dośw̧iadczenie we wielu sprawach i znajomość różnych nauk często uchodzi niemal za proroka. Kto zaś pozostawiony sam sobie błądziłby jak ślepiec $\mathrm{w}$ ciemnościach, przecież z pomocą Pana dochodzi niekiedy do takiego poznania prawdy, że przekazują ją innym i często staje się tak pożyteczny, sławny i znany, że możni domagają się go 
pius efficitur fructuosus, gloriosus et famosus, ut a magnatibus postulatur pro directore, cum sapientium sit regere. Nec non qui alias nescivisset se debite habere circa unum hominem aut personam, interdum redditur proficuus erga totam communitatem vel provinciam. Immo qui ex se

5 sire studio vix scivisset loqui de statu praesentis vitae, nonnumquam virtute studii constituitur gloriosus viator et contemplator, immo comprehensor caelestis patriae. Ideoque ut nos universi sic celebremus istas exequias, quod nobis et huic gloriosae Dominae valeant proficere et Altissimo concedente de hac materia possim aliqua pro utilitate dicere, pro

10 gratia impetranda dicamus mente devota „Ave Maria”. |

$W f .124 v$ Celebravit exequias universus Iuda - ubi supra. Venerabiles magistri et domini! Ex quo lex naturae a nobis exigit consimilem pietatem aliis exhibere, quam nobis tempore opportuno vellemus fieri, et quia quilibet nostrum, dum, quod absit, in suppliciis purgatorii existeret, vellet sibi

15 a suis successoribus pro eius liberatione suffragari, praesertim ab his, quibus se verbo vel facto commisit, velut aestimandi sunt quibus bona sua dereliquit aut certa opera pietatis exhibuit et cum quibus familiaritatem conversationis tenuit vel fraternitatem cognationis aut societatis habuit, ex quibus ratione singularis obligationis vel cuiusdam evidentis

20 promissionis aliqualem spem subveniendi recepit, prout ratio humana aliquantulum concludit.

Et hinc est, cum de beatificatione et omnimoda liberatione huius excellentissimae Dominae, matris nostrae, simus aliquantulum dubii et non omnino securi, ideoque secundum ius naturae, ut de beneficiis suis

25 nobis impensis videamur grati, tenemur eidem ad praesens succurrere velut qui spiritualia, si non corporalia, ex parte suae serenitatis recepimus emolimenta. Et in signum aliqualis huiusmodi recompensationis insistimus praesentibus exequiis.

Quas exequias ut nunc et peramplius fructuosius peragamus, recur30 rendum est ad causas, propter quas exequiae communiter fieri consueverunt. Et tales sunt duplices, scilicet verae et laudabiles, falsae et vituperabiles. Modo verae et laudabiliter pro aliquo peraguntur exequiae, quando eadem fiunt ex instinctu Dei et ordinatione Ecclesiae, cum affectu pietatis et exhibitione humilitatis. False autem et vituperabiliter

35 celebrantur, quando fiunt ex instinctu diaboli et appetitu vanae gloriae, cum quadam ostentatione et gloriatione.

18 vel del. sub aut.

25 benedicte domine del. post eidem.

26 corporalia nobis del. post qui.

32 fiunt. del. post peraguntur. 
jako przywódcy, gdyż sprawowanie rządów jest zadaniem mędrców. Podobnie ten, kto skądinąd nie umiałby się stosownie zachować wobec jednegc człowieka lub jakiejś osobistości, czasem staje się pożyteczny dla całej gminy lub kraju. Jednym słowem taki, który nie mając za sobą studjów umiał zaledwie rozmawiać o sprawach codziennego życia, uszlacheiniony nauką kieruje swój umysł ku niebieskiej ojczyźnie, jak zatopiony $w$ myślach sławny pielgrzym. Dlatego też, abyśmy wszyscy odprawili te egzekwie z pożytkiem dla siebie oraz dla tej przesławnej Pani, i bym ja zdołał za Bożym przyzwoleniem z korzyścią rozwinąc podjęty temat, odmówmy pobożnie „Zdrowaś Mario” dla wyproszenia sobie łaski.

Cały Judo odprawit uroczystości pogrzebowe (jak wyżej). Czcigodni magistrzy i panowie! Skoro prawo natury wymaga od nas darzenia innych tą samą życzliwością, jakiej sami spodziewamy się $\mathrm{w}$ trudnych dla nas chwilach i gdyby ktokolwiek z nas znalazłszy się, co nie daj Boże, wśród mąk czyśćcowych, chciał, aby wybawiła go pomoc, udzielona mu przez tych szczególnie sukcesorów, którym polecił się słowem lub uczynkiem, a za takich powinno się uważać osoby, którym pozostawił swój majątek lub w konkretnych uczynkach okazał swą życzliwość i z którymi utrzymywał zażyłe stosunki lub łączyło go braterskie pokrewieństwo czy więź społeczna, to taki przeto, na ile rozum ludzki pozwala wyciągnąc tutaj jakieś wnioski, nabrał nadziei otrzymania pomocy na podstawie owego szczególnego zobowiązania lub też jakiejś wyraźnej obietnicy.

Dlatego też, ponieważ nurtują nas jeszcze pewne wątpliwości i nie jesteśmy całkowicie pewni czy ta najznakomitsza Pani, matka nasza, została już całkowicie zbawiona i cieszy się wieczną szczęśliwością, przeto zgodnie z prawem natury, aby okazać swą wdzięczność za wyświadczone nam przez nią dobrodziejstwa, powinniśmy obecnie przyjść jej z pomocą jako ci, którzy czerpali z niej korzyści duchowe, jeśli nie materialne. Na znak więc tego rodzaju skromnej wdzięczności postanawiamy odprawić te egzekwie.

Abyśmy jednak mogli teraz i w przyszłości odprawiać z większym pożytkiem takie egzekwie, należy się najpierw zastanowić nad tym, co jest powodem, że zwykło się je w ogóle urządzać. Składają się na to dwojakiego rodzaju przyczyny, mianowicie prawdziwe i godne pochwały oraz fałszywe i godne potępienia. Odprawia się egzekwie za kogoś w sposób prawdziwie chwalebny, jeśli odbywają się one z natchnienia Bożego i Kościelnego ustanowienia w duchu miłości i wyraźnej pokory. Fałszywe zaś i godne potępienia odprawianie egzekwii ma miejsce wówczas, kiedy z poduszczenia szatańskiego i przez pożądliwość próżnej chwały urządza się je z pewną ostentacyjną wystawnością. 
Et haec prosequendo faciam sicut colonus, qui ad colendum et seminandum agrum, ut utiliter fructificet, primo exstirpat malas radices et deinde superseminat grana fructifera. Sic primo dicam de causis falsis, ex quibus vituperabiliter aliquando fiunt exequiae. Et huiusmodi sunt

5 triplices: quarum una est, ut nomen defuncti in maiori veneratione haW f. 125 beatur; alia est, ut vita ipsius aliquantulum | laudibus extollatur; tertia, ut lucrum temporale ex hoc acquiratur. Et his de causis quam pluries sunt exequiae non obstante, quod ita exequias facere sit magis nocivum quam proficuum, prout illud ex tribus liquide colligitur. Et primo ex eo,

10 quia sic facientes exequias percutiuntur vana gloria et sine profectu perdunt quae exponunt eo, quod de eis sic verificatur illud dictum Salvatoris [Mt 6, 2]: Amen dico vobis, receperunt mercedem suam $\left(M t . V^{\circ}\right)$, et iterum: Omnia opera sua faciunt, ut videantur ab hominibus, ibidem $23[5]$.

15 Secundo, quia interdum clerus in huiusmodi exequiis plus intendit avaritiae et crapulae, quam devotioni et contemplationi. Unde in communi proverbio dicitur: De morbo gaudet medicus et de morte sacerdos, eo quod sicut occasionaliter morbus nutrit medicum, sic cadaver clerum.

Tercio, quia sic mortuis suffragium praestitum occasione eiusdem

20 pravae intentionis subtrahitur et supplicium aliquantulum prolongatur, in quantum ibi concurrit multimoda vanitas et superstitiosa curiositas. Unde dicit beatus Augustinus decimo ,De civitate Dei', quod pompaticae plus sunt solatia vivorum, quam subsidia mortuorum. Modo quamvis sic inaniter aliquando fiant exequiae, nihilominus propter hoc non sunt

25 absolute exequiae inculpandae et prohibendae neque mentes hominum ab eisdem operibus avertendae, sicut quidam perfidi minus provide facere nituntur, dicentes, quod ibidem concurrat indevota multiplicatio vigiliarum et pomposa congregatio turbarum, iuxta quod ait metrista:

Dum moritur dives, concurrunt undique cives.

Pauperis ad funus

vix adest clericus unus.

7 respectu cleri extendatur del. post acquiratur.

9 breviter del. post tribus.

12 quia del. post suam.

13 Mt del. post ibidem.

15 cleros sic ms. (cf. supra p. 50, 7).

17 de morbo - - sacerdos, cf. H. Walther, Proverbia sententiaeque latinitatis medii aevi, Göttingen 1963, nr 5094.

22 cf. s. Augustinus, De civitate Dei, PL 41, 26.

29-32 dum - - unus, cf. H. Walther, op. cit., $n r 6614$. 
Rozwijając tę myśl z pomocą Bożą, postąpię jak wieśniak, który przystępując do uprawy i obsiania roli, by przyniosła ona obfity plon, najpierw usuwa $\mathrm{z}$ niej chwasty, a następnie zasiewa owocne ziarno. Tedy i ja omówię w pierwszym rzędzie fałszywe przyczyny urządzania egzekwii, nieraz godnych potępienia. A są one trojakie: pierwsza z nich ma na celu przydanie imieniowi zmarłej osoby większej czci; druga wysławianie $\mathrm{w}$ pochwałach życia zmarłego; trzecia - osiągnięcie doczesnej korzyści. Dla tych właśnie powodów bardzo często urządza się egzekwie bez 〈niczyjego〉 sprzeciwu, mimo, że odprawiane $w$ ten sposób przynoszą więcej szkody niż pożytku, jak to wyraźnie wynika $\mathrm{z}$ trzech okoliczności. Po pierwsze $\mathrm{z}$ tego, że odprawiających egzekwie rozsadza próżna chwała i na marne idzie to, co wystawiają na pokaz publiczny, gdyż do nich stosują się owe słowa Zbawiciela (Mt 6, 2): Zaprawdę powiadam wam, otrzymali już swoją zapłatę, i nieco dalej (Mt 23, 5): Wszystkie swe czyny spełniają $\mathrm{w}$ tym celu, żeby się ludziom pokazać.

Po drugie kler na tego rodzaju egzekwiach bardziej oddaje się chciwości i pijaństwu niźli pobożności i rozmyślaniu. Dlatego też potoczne przysłowie powiada: Z choroby cieszy się lekarz, a ze śmierci ksiądz, bo jak choroba jest przypadkowo pożywką dla medyka, tak trup dla kleru.

Po trzecie, udzielona $\mathrm{w}$ ten sposób pomoc zmarłym oddala się od nich z powodu przewrotnej intencji i męka ich nieco się przedłuża na ile przy takich egzekwiach wieloraka próżność łączy się ze zgubną wystawnością. Powiada przeto św. Augustyn w X księdze „O państwie Bożym”, że okazałe egzekwie są raczej pociechą żywych aniżeli wsparciem dla zmarłych. Lecz chociaż czasem na próżno odprawia się egzekwie, to jednak nie powinno się ich całkowicie potępić i zakazać, ani też ludzie nie powinni odsuwać myśli od spełniania takich uczynków, jak to nierozważnie starają się postępować niektórzy obłudnicy, powiadając, że jest to połączenie bezbożnej zapobiegliwości o coraz okazalszy przepych i demonstracyjne gromadzenie tłumów, zgodnie z tym co mówi poeta:

Gdy śmierć zabiera bogacza, zewsząd zbiegają się ludzie.

Lecz za pogrzebem biedaka, nikt prócz kapłana nie pójdzie. alburáf' 
Immo, sicut huiusmodi asserunt, adest etiam iocunda et quasi derisiva consessio pulvinarium, impetuosa pulsatio companarum, infructuosa multiplicatio expensarum, inordinata largitio elemosinarum et immoderata consumptio candelarum ac varia insania sicut amicorum comminatio, sti-

5 parum convocatio, vana confabulatio, missarum accurtatio, superflua sollicitudo et conscientiarum aggravatio. Nam sic facere exequias, non est exequiis uti sed abuti. Propter autem abusum res in se non sunt prohibitae nec prohibendae eo, quod alias non deberemus bibere nec

$w f .125 v$ comedere, cum talibus solemus | saepius abuti. Nec est res communiter

10 tam bona, quin propter abusum verti possit in malum. Et quia apud Deum non perit, quidquid pro mortuis diligentia hominum persolvit, ut habetur in canone $13^{\text {a }}$ quaestione $2^{\text {a }}$, et ignoramus quibus mortuis prosunt vel non prosunt exequiae, ideo pro nullo debemus eas omittere. prout in eodem canone habetur. Unde, ut videamus veri confessores fidei

15 verbo quam facto, secundum designitionem thematis propositi sub hoc nomine Iuda, universi sic celebremus praesentes exequias, ut fugiamus falsas causas nunc praemissas et quaeramus versas cum aliis correquisistis. Et tantum de primo.

Quantum autem ad secundum, causae verae, ex quibus laudabiliter

20 fiunt exequiae, similiter sunt triplces. Quarum una est, ut de morte Christi et de nostro peccato, quod fuit causa suae mortis, cogitemus; alia est, ut perpendendo miserias defunctorum interim, quod vivimus, in bonis moribus et meritoriis operibus vitam per poenitentiam corrigamus; tertia, quod nostris orationibus et aliis piis operibus in purgatorio exi-

25 stentibus adiutorium impendamus. Huiusmodi enim considerationes sunt multum laudabiles eo, quod tollunt de facili occasionem peccandi. Nam quid valet avaritia, cum defunctis non prosint bona temporalia, nisi in quantum erant quaedam media ad opera meritoria? Sic quid prodest superbia et iactantia, cum necesse sit hominem incinerari et a vermi-

30 bus consumi? Similiter quid valet gula et luxuria, cum cartissimo experimento hominis cadaver mortuum fore foetidius et horribilius ceteris bestiarum cadaveribus eo, quod caro quanto delicatius nutritur tanto exanimata foetidior efficitur? Et sicut maligni spiritus per peccata dominati fuerunt super corpus vivum, sic amplius aliquando dominantur super

35 ipsum, cum fuerit mortuum.

Sed ut evidentius credamus suffragia vivorum proficere animabus defunctorum, opportet nos sequentia praesupponere et pro evidenter

4 candalarum $m s$.

12 cf. Decreium. Gratiani, pars II causa 13. In: Corpus Iuris Canonici, ed. A. Frieaberg. Lipsiae 1879, vol. I.

22 attendentes ad del. sub ut perpendendo. 
W ogóle twierdzą oni, że takie uroczystości sprowadzają się również do wesołego i niemal szyderczego rozsiadywania się na miękkich poduszkach, do gwałtownego bicia w dzwony, bezużytecznego pomnażania wydatków, chaotycznego szafowania jałmużną, nieograniczonego wyświecania świeczników, że temu towarzyszą różne pozbawione sensu czynności, jak pogróżki przyjaciół, zwoływanie na stypy, prowadzenie czczych rozmów, skracanie mszy św., nadmierna zapobiegliwość i obciążanie sumień. Odprawianie bowiem egzekwii w ten sposób jest w rzeczywistości ich nadużywaniem. Jednakże $z$ powodu nadużycia rzecz sama w sobie nie została i nie powinna być zakazana, gdyż na tej samej zasadzie nie powinniśmy pić ani jeść, skoro zazwyczaj dość często przebieramy w tym miarę. W ogóle rzecz cała nie jest aż tak dobra, ażeby przez nadużycie nie mogła stać się złą. A ponieważ u Boga nic nie idzie na marne z tego co gorliwość ludzka uczyniła dla zmarłych, jak powiedziano w kanonie 13 kwestii 2, my zaś z kolei nie wiemy komu ze zmarłych egzekwie przynoszą pomoc lub nie przynoszą, dlatego nie powinniśmy ich szczędzić nikomu zgodnie z zaleceniem tegoż kanonu. Żebyśmy zatem mogli okazać się prawdziwymi wyznawcami wiary zarówno w słowie jak i czynie, dostosujmy się do przewodnich słów tego kazania i wszyscy, jak ów Juda, odprawmy obecne egzekwie tak, aby uniknąć wymienionych fałszywych powodów i poszukać prawdziwych oraz innych istotnych pobudek. Tyle na temat pierwszej kwestii.

Co się tyczy drugiej, to są również trzy rodzaje prawdziwych przyczyn, sprawiających, że egzekwie odbywają się w sposób chwalebny. Celem pierwszej z nich jest pamiętanie o śmierci Chrystusa i o tym, że spowodowały ją nasze grzechy; druga - abyśmy już teraz przez rozważanie smutnego położenia zmarłych, sami naprawili swoje życie dzięki pokucie, żyjąc obyczajnie i spełniając uczynki zasługujące na nagrodę; trzecia - abyśmy naszymi modlitwami i innymi dobrymi uczynkami spieszyli z pomocą przebywającym w czyśćcu. Tego rodzaju rozważania są szczególnie godne pochwały, ponieważ łatwo usuwają sposobność do grzechu. Jakież bowiem znaczenie ma chciwość, skoro dobra ziemskie w niczym zmarłym nie pomagają, o ile nie służyły one za środek do spełniania dobrych uczynków? Na cóż zda się również pycha i przechwałki, kiedy człowiek i tak się musi w proch obrócić i w końcu zjedzą go robalki? Podobnie jakąż korzyść przynosi obżarstwo i rozpusta, gdy jest rzeczą doświadczalnie sprawdzoną, że martwe ciało człowieka będzie o wiele obrzydliwsze i bardziej odrażające niż zwłoki pozostałych zwierząt, bo im delikatniejszy pokarm żywi ciało, tym bardziej odrażające staje się ono po śmierci. A złe duchy, jak zawładnęły ciałem ludzkim dzięki grzechom, to tym bardziej zawładną nim wówczas, gdy już będzie martwe. 
conclusis habere. Et primo oportet nos praesupponere animae perpetuiw f. 126 tatem; secundo talem in futuro fieri | animae remunerationem, qualem ipsa de praesenti promeruit in corpore; tertio - non omnes animas hominum post exitum a corpore mox beatificari neque damnari, sed aliquas 5 a beatitudine retardari.

Quorum primum, scilicet animae humanae perpetuitas, patet per illud Sapientiae secundo [23]: Creavit Deus hominem inexterminalem. Et quia, sicut constat, hoc non intelligitur quantum ad corpus et per consequens intelligitur quoad animam. Idem patet illud Matthaei $\mathrm{X}^{\circ}$ [28]:

10 Nolite timere eos, qui occidunt corpus, animam autem non possunt occidere. Quod dictum utique esset impertinens, nisi homo haberet animam immortalem. Et ratio, quia alias non videtur, unde magis pro anima humana fieri deberent suffragia quam pro anima brutali, si similiter esset corruptibilis.

15 Secundum vero, quod animae praemium fiet secundum eius meritum. Patet illud Mt. 16 [27]: Filius hominis venturus est in gloria Patris sui cum angelis suis et tunc reddet unicuique iuxta opera sua. Et per illud „opus suum” probet unusquisque in se ipso, quia quisque onus portabit [Gal. 6, 5]. Nam quae seminaverit homo, haec metet; quoniam qui se-

20 minat in carne de carne sua et metet corruptionem; qui autem 〈seminat $>$ in spiritu, de spiritu [et] metet vitam aeternam [Gal. 6, 8].

Tertium autem, quod non omnes animae post exitum a corpore mox beatificantur nec dampnantur, sed aliquae in purgatorio retardantur, patet quia aliquae licet in caritate exeunt, non tamen pro commisis satis25 fecerunt vel in eis aliqua venialia purganda remanserunt. Unde dicit beatus Augustinus, quod animae decedentium sunt triplices: quaedam valde bonae, quaedam valde malae et aliae mediae: nec valde bonae, nec valde malae. Et subiungit, quod sacrificia et elemosinae, quae fiunt pro valde bonis, sunt gratiarum actiones; pro valde malis, quamvis non sint adiu-

30 vamenta mortuorum, sunt tamen consolationes vivorum, ad quorum meritum et non mortuorum succedunt; sed mediis, non valde bonis neque malis, sunt propitiationes, quia valent ad celeriorem liberationem a poenis. Ideo etiam apostolus primae $\langle$ ad $\rangle$ Chorintios $3^{\circ}$ dicit Christum esse fundamentum beatitudinis et quod aliqui superaedificant aurum, argentum et lapides praeciosos, id est maiora, media vel minora opera gratuiw f. $126 v$ ta, alii vero superaedificant lignum, faenum vel stipulam | et quod unius- 
Aby zatem nasza wiara w skuteczność pomocy niesionej przez żywych duszom zmarłym stała się bardziej autentyczna, musimy z kolei przedstawić pewne wnioski i uznać je za zupełnie oczywiste. Najpierw więc należy omówić zagadnienie nieśmiertelności duszy ludzkiej; po wtóre, że taka nagroda czeka duszę w przyszłości, na jaką zasłużyła sobie ona, przebywając w ciele ludzkim; po trzecie, że nie wszystkie dusze ludzkie po opuszczeniu ciała zostają od razu zbawione czy potępione, lecz że zbawienie niektórych następuje z opóźnieniem.

Pierwsze z tych zagadnień, tzn. nieśmiertelność duszy ludzkiej, jest wyjaśnione słowami Księgi Mądrości (2, 23): Stworzył Bóg człowieka dla nieśmiertelności. Wiadomo wszakże, że myśl ta nie odnosi się do ciała, przeto rozumie się ją w odniesieniu do duszy. To samo mówi Mateusz $(10,28)$ : Nie bójcie się tych, którzy zabijają ciało, lecz duszy zabić nie mogą. Słowa te byłyby całkowicie pozbawione sensu, gdyby człowiek nie miał nieśmiertelnej duszy. I słusznie, bo gdyby dusza ludzka podlegała podobnemu unicestwieniu, jak dusza zwierzęca, to człowiek nie wiedziałby, której z nich ma gorliwiej świadczyć pomoc.

Drugie zaś, tzn. że nagroda duszy jest odpowiednia do jej zasługi, jasno wynika ze słów Mateusza $(16,27)$ : Syn człowieczy przyjdzie w chwale Ojca swego razem z aniołami swymi i wtedy odda każdemu według jego uczynków. Przez ten zaś ,,swój uczynek” każdy niech osobiście dowiedzie, że poniesie swój ciężar (Gal. 6, 5). Albowiem co człowiek zasieje, to i żąć będzie; ponieważ kto sieje w ciele swoim, jako plon ciała zbierze zgniliznę, kto zaś sieje w duchu, jako plon ducha zbierze życie wieczne (Gal. 6, 8).

Co do trzeciego, a mianowicie, że nie wszystkie dusze bezpośrednio po opuszczeniu ciała nie dostępują zbawienia czy potępienia, lecz niektóre zatrzymują się w czyśćcu, to z tego jasno wynika, że pewne dusze, chociaż w miłości schodzą z tego świata, jednak nie odpokutowały wystarczająco za popełnione przewinienia, albo też obciążone jakimiś lekkimi grzechami wymagają oczyszczenia. Dlatego powiada św. Augustyn, że są trzy rodzaje dusz opuszczających ten świat: jedne są bardzo dobre, drugie bardzo złe, a inne pośrednie - ani bardzo dobre, ani bardzo złe. Dodaje również, że ofiary i jałmużna, składane w intencji dusz bardzo dobrych, są rodzajem dziękczynienia; składane w intencji dusz bardzo złych, choć nie przynoszą pomocy zmarłym, są wszakże pociechą dla zywych i im, a nie zmarłym, poczytuje się je za zasługę; lecz za dusze pośrednie, tzn. ani bardzo dobre ani bardzo złe, zanosi się modlitwy przebłagalne, ponieważ mogą one znacznie przyśpieszyć uwolnienie tych dusz od kar. Dlatego też apostoł w I liście do Koryntian (3, 11-13) po- 
cuiusque opus ignis probabit, par quae intelliguntur peccata venialia maiora, media et minora, quorum primum diutus punitur, secundum vero medio modo et tertium brevissime, velut lignum diutius ardet quam faenum et faenum quam stipula.

Ex quibus praemissis sequitur primo, quod nonnullae animae defunctorum indigent suffragiis vivorum. Patet, quia sicut multae animae sunt in caelo, et multae in inferno, sic aliquae sunt in purgatorio, cum purgatorium sit medium inter ista dua extrema, medium autem sapit naturam extremorum. Et ergo, sicut quaedam sunt in caelo et quaedam in

10 inferno, sic quaedam sunt in purgatorio. Secundo sequitur, quod solum animae in purgatorio existentes indigent suffragiis eo, quod solum tales inter animas defunctorum habent poenas temporales. Tertio sequitur, quod securius est hic bene vivere, quam post mortem ab aliis liberationem exspectare, cum beatius sit liberum exire, quam post captivitatem

15 liberationem quaerere. Quarto sequitur, quod tutissima via est bonum, quod quisque post mortem suam sperat gratia sui per alios agendum, agere per se ipsum, cum praeteritum sit certius quam futurum. Quinto, qui pro aliis recto ordine vult suffragia facere, debet a se ipso incipere eo, quod ordinata caritas incipit a se ipso. Unde Ecclesiastici $4^{\circ}$ dicitur: 20 Qui sibi nequam, cui bonus?

Ultra autem ista praemissa, quidam nefarie asserunt, quod sacerdotes in peccatis existentes non prosunt defunctis in tricesimis et in aliis divinis officiis. Et hoc probant per illud Ysaiae primo [14-15]: Non offeratis ultra sacrificium frustra; incensum [vestrum] abominatio mihi

25 est $\langle-\longrightarrow\rangle$ cum extenderitis manus vestras, avertam oculos meos $\langle$ a vobis $\rangle$; et cum multiplicaveritis orationes vestras, non exaudiam. Et ratio horum subiungitur: Iniqui - inquit - sunt coetus vestri et manus vestrae plenae sunt sanguine, id est operationes vestrae repletae sunt peccatis. Et idem confirmant per illud Malachiae primo [7-10]: Offertis super 30 altare meum panem pollutum $\langle->$ Non est mihi voluntas in vobis, dicit Dominus (exercituum) et manus non suscipiam de manu vestra. Ubi dicit beatus Jeronimus in glossa: Corpus Christi polluit qui indignus ad altare accedit. Et ut dicit Gregorius in ,Pastorali': Cum is, qui displicet, ad intercedendum mittitur, irati animus procul dubio ad deterius

35 provocatur, qualis esse videtur sacerdos criminosus. Sed revera huiusmodi fallunt et falluntur. Nam licet sacerdotes criminales ex opere operante non placeant Deo, tamen ex opere operato, id est placent ex offi-

20 qui - - bonus, cf. Eccli 14, 5: Qui sibi nequam est, cui alii bonus erit?

21 nepharie $m s$. 
wiada, że Chrystus jest fundamentem zbawienia i że niektórzy budują na nim ze złota, srebra i drogich kamieni, tzn. dają większe, pośrednie lub mniejsze dowody wdzięczności, inni zaś budują [na tym fundamencie] z drzewa, siana lub słomy; że dzieło każdego przejdzie próbę ognia, przez co rozumie się grzechy powszednie cięższe, średnie i lżejsze, z których pierwszy podlega dłuższej karze, drugi trochę krótszej, a trzeci najkrótszej, podobnie jak drzewo pali się dłużej niż siano, a siano niż słoma.

$\mathrm{Z}$ powyższego wynika po pierwsze, że są dusze zmarłych potrzebujące pomocy żywych. Jest rzeczą oczywistą, że jak w niebie jest wiele dusz i wiele jest ich w piekle, tak są też jakieś w czyśćcu, gdyż czyściec jest czymś pośrednim między tymi dwiema skrajnościami, a rzecz pośrednia stara się przyjąc naturę rzeczy skrajnych. Skoro zatem pewne dusze są w niebie, inne w piekle, to i w czyśćcu przebywają jakieś dusze. Po drugie, tylko dusze przebywające w czyśćcu porzebują pomocy, gdyż one jedne spośród innych dusz osób zmarłych mają kary ograniczone w czasie. Po trzecie, bezpieczniej jest pędzić życie doczesne w sposób szlachetny, aniżeli po śmierci wyczekiwać zbawienia za sprawą innych, bo szczęśliwiej jest opuścić ten śwat wolnym, niźli poniewoli rozglądać się później za zbawieniem. Po czwarte, najpewniejsza droga do tego prowadzi przez bezpośrednie świadczenie dobra, którego po śmierci każdy od swoich bliźnich oczekuje, albowiem przeszłość jest pewniejsza od przyszłości. Po piąte, ten kto chce w godziwy sposób przyjść z pomocą innym, winien zacząć od siebie samego, jako że miłość rozważna poczyna od siebie. Dlatego czytamy u Ekklezjastyka $(14,5)$ : Kto jest zły dla siebie, dla kogóż będzie dobry?

Są zaś jeszcze tacy, którzy bezbożnie twierdzą, że kapłani będący w stanie grzechu nie niosą pomocy zmarłym, ani wtedy gdy odprawiają msze gregoriańskie, ani przez odmawianie innych modlitw kapłańskich. Dla poparcia swego stanowiska, przytaczają słowa Izajasza (1, 13-15): Przestańcie składania czczych ofiar! Obrzydłe mi jest wznoszenie dymu $\langle-\longrightarrow\rangle$ Gdy wyciągniecie ręce, odwrócę od was swe oczy; choćbyście nawet mnożyli modlitwy, ja nie wysłucham. W uzupełnieniu sensu tych słów dodaje: Bezprawne są wasze zebrania i ręce wasze pełne są krwi, tzn. uczynki wasze wypełniły się grzechami. Potwierdzenie tego samego znajdują u Malachiasza (1, 7-10): Przynosicie na mój ołtarz skażone potrawy $\langle-\longrightarrow$ Nie mam ja upodobania w was, mówi Pan zastępów, i nie jest mi miła ofiara $z$ ręki waszej. Do tego św. Hieronim dodaje w swojej glossie: Ciało Chrystusa skaził ten, kto nie będąc w stanie łaski, przystąpił do ołtarza. Również Grzegorz W. w Moraliach mówi: Jeśli na po- 
w f. 127 cio, licet non ex se ipso. Deus autem non semper | respicit ad merita personarum, sed interdum ad officia. Et sic licet missae malorum sacerdotum non prosint aliis ex eorum meritis, prosunt tamen ex parte officii et merito Christi. Recte, sicut passio Christi ex parte sui oblati in

5 cruce profuerit nobis sed non ex parte offerentium sive crucifigentium, sic suo modo oblatio Christi in sacrificio missae semper prodest ex parte Christi oblati, licet non semper ex parte ministri offerentis. In simili, sicut cibus bene paratus ex se placet comedentibus, licet non ex parte ministri immundi. Qui cibus tamen esset acceptior, dum minister esset 10 mundus et bene dispositus. Et ita est etiam de sacerdotibus, quod eorum oblatio placet Deo ex officio et plus placeret, dum bene viverent. Et ex istis apparet quibus defunctis suffragia succurrunt et ex parte quorum.

Quae autem sunt suffragia defunctorum, ad hoc plane respondet beatus Thomas in libro ,De veritate', dicens, quod animae defunctorum 15 quatuor modis solvuntur - et idem habetur in canone - quia aut oblationibus sacerdotum, aut precibus sanctorum, aut elemosinis carorum, vel ieiuniis cognatorum. Quod dictum non est intelligendum quantum ad meritum vitae aeternae eo, quod illud per se meruerunt dum vixerunt, sed quantum ad mitigationem poenae et ad accelerationem gloriae. In-

20 ter quae suffragia praemissa oblatio salutaris hostiae est maximum eo, quod in ipsa offertur Christusmet, qui est mediator Dei et hominum. Et licet in qualibet missa pro defunctis agatur, in qua nullus in purgatorio existens excluditur, sicut etiam perfidi loquuntur, nihilominus illi specialiter missa suffragatur, cui officiositas magis afficitur et plus obli-

25 gatur et qui in maiori gratia decessit, ex qua ampliorem succursum promeruit eo, quod Deus partitur meritum pro his, qui sunt in purgatorio, iuxta quod hic vivendo obtinuerunt, ut eis post mortem succurrunt ea, Wf.127v quae pro eis | hic fiunt in quantum in maiori gratia decesserunt et maiorem succursum meruerunt.

30 Cum timore tamen et dolore attendere debent mali sacerdotes, quod ipsi in sacro officio aliis prosunt et sibi ipsis, proh dolor, obsunt et quod eorum benedictio convertitur eis in maledictionem iuxta illud Malachiae II ${ }^{\circ}$ [2]: Maledicam benedictionibus vestris; et quod de eis verificatur illud Osee VIII ${ }^{\circ}$ [11]: Multiplicavit Effraym altaria ad peccandum et fac35 tae sunt ei arae in delictum. Effraym enim interpretatur „crescens” et

28 hic del. post succursum.

32 benedictionem del. post eis. 
średnika kieruje się kogoś niemiłego, nie wątpię, że to wzbudza w zagniewanym jeszcze gorszy gniew, a takim jest chyba kapłan obciążony grzechami. W istocie rzeczy ci, którzy tak mówią, oszukują siebie i innych. Jeżeli bowiem występni kapłani nie podobają się Bogu z uwagi na zakres mocy działającego, to jednak są mu mili ze wględu na rzecz wykonywaną, tzn. obowiązek kapłański, choć nie ze względu na siebie samych. Bóg zaś nie zawsze zważa na postępki ludzkie, ale często na wykonywane przez nich obowiązki. Jakkolwiek więc msze odprawiane przez złych kapłanów nikomu nie przynoszą żadnej korzyści z powodu ich występków, to jednak pomagają ze względu na wykonywaną powinność i dzięki zasłudze Chrystusa. I słusznie, bo jak z męki Chrystusa czerpiemy korzyść dzięki temu, kto został ofiarowany na krzyżu, a nıe dzięki tym, którzy tę ofiarę składali czyli przybijali do krzyża, tak na swój sposób ofiara Chrystusa w ofierze mszy św. zawsze jest pomocna dzięki ofiarowywanemu Chrystusowi, choć nie zawsze dzięki temu, kto tę ofiarę sprawuje. Zupełnie tak samo jest z potrawami, które smakują jedzącym dlatego, że są dobrze przyrządzone, pomimo że są podane przez niechlujnego sługę. Oczywiście, że lepiej by one smakowały, gdyby sługa wyglądał schludnie i był dobrze ułożony. Podobnie jest $\mathrm{z}$ kapłanami, gdyż spełniana przez nich ofiara jest miłą Bogu z racji wykonywanego obowiązku, a podobałaby się jeszcze bardziej, gdyby prowadzili cnotliwe życie. Na tej podstawie staje się jasne, komu ze zmarłych świadczona pomoc przynosi pożytek i co jest jej źródłem.

$\mathrm{Na}$ pytanie zaś, jakie uczynki przynoszą zmarłym pomoc, jednoznacznej odpowiedzi udziela św. Tomasz w dziele O prawdzie, powiadając, że zbawienie dusz zmarłych dokonuje się w czworaki sposób (to samo podaje prawo kanoniczne), a mianowicie albo przez kapłańską ofiarę we mszy św., albo dzięki prośbom zanoszonym przez świętych, albo dzięki szczodrobliwości bliźnich, albo przez posty krewnych. Słów tych nie należy rozumieć jako sposobu osiągnięcia łaski życia wiecznego, bo na nie sami sobie zasłużyli, gdy żyli na ziemi, lecz tylko jako środka do złagodzenia kary i przyśpieszenia swojej chwały w niebie. Spośród wymienionych uczynków przebłagalnych najważniejsza jest zbawcza ofiara eucharystyczna, ponieważ w niej się ofiaruje sam Chrystus, który jest pośrednikiem między Bogiem i ludźmi. Jakkolwiek ofiara ta dokonuje się w każdej mszy św. żałobnej, w której, jak powiadają ludzie przewrotni, nikt $\mathrm{z}$ przebywających $\mathrm{w}$ czyśćcu nie jest pominięty, to jednak msza św. przynosi pomoc zwłaszcza temu, do kogo ta posługa szczególniej się stosuje i kto jej bardziej wymaga, tzn. w im kto większym stanie łaski umarł, na tym hojniejszą pomoc sobie zasłużył dlatego, 
significat „sacerdotium", quod crescere deberet in virtutibus et bonis operibus, ut tamquam speculum honestatis augeret populum Domini. Sed heu, quasi totus clerus hodie factus est sterilis et infructuosus tam in se quam quoad populum eo, quod secundum prophetam multiplicavit

5 altaria ad peccandum, in quantum deficit in officio divino propter desidiam vel criminalem culpam in eo, quod plus insistit gulae vel luxuriae quam divino officio, vel quia indigne conversatur circa altare Domini. Unde notanter dicit propheta, quod multiplicavit sibi altaria ad peccandum per commissionem malorum et quod arae factae sunt ei in

10 delictum quantum ad omissionem bonorum eo, quod in utroque nonnumquam excedunt. Quapropter Levitici XXI [21] in figura de eis dicitur, quod omnis, qui habuerit maculam de semine Aaron sacerdotis, non accedat hostias offerre Domino nec panes Deo suo. Patet, quia sibi obest non prodest.

15 Utinam illa et similia pensaremus et dissolutions ac vanitates, otia et scandala fugeremus et essemus magis assidui in servitio Dei, praecipue his malis temporibus, quibus clerus quasi ab omnibus habetur exosus. Et fortasse non immerito eo, quod licet Domino concedente plures simus numero in divino officio, pauci tamen actu in cottidiano

20 sacrificio; nomine quidem sacerdotes sed non resacrificantes. Cum tamen esse in sacro officio et illud sine causa non explere in effectu non sit sine notabili defectu nec absque evidenti vitio, quod, ut videtur, includit causam repulsionis et notam non remunerationis, immo importat signum dissolutionis, indispositionis et divagationis magis quam devotio-

25 nis, attentionis et praeparationis - nam licet nullus voluerit habere servum nisi serviat et coquam nisi decoquat - nihilominus volumus esse sacerdotes et non sacrificantes nec sacra dantes neque sacra docentes, immo, si fas esset dicere, nec sacra audientes et minus legentes et minime operantes et per consequentiam non curantes quam nosmet ipsos ac

30 alios aedificemus. Quod utique non faceremus, si divinam iustitiam perpenderemus et eius ultionem prae oculis haberemus.

Et praesertim debite advertemus habitudinem purgatorii, quomodo wf.128 locus ille facilis est quoad ingressum | et valde gravis quantum ad sup-

\footnotetext{
2 ex hoc del. post ut.

9 propter del. sub per.

26 cocam $m s$.

28 phas $m s$.

31 post haberemus in $m s$. repetita verba sequentis sententiae: et debite advertemus.

18-31 et fortasse - - haberemus in margine infimo f. $127 v-128 v$ auctor(?) inscripsit.
} 
że Bóg nagradza przebywających w czyśćcu według tego, jak oni sobie na to za życia zasłużyli, bo po śmierci przynosi im pomoc to, co się tu na ziemi dla nich robi, i w im większej łasce zeszli $\mathrm{z}$ tego świata, na tym większą pomoc sobie zasłużyli.

Jednakże występni kapłani, przejęci lękiem i boleścią, winni mieć na uwadze to, że pełniąc służbę Bożą, sami niosą pomoc innym, ale sobie wyrządzają niestety szkodę, i że ich błogosławieństwo przemienia się dla nich w przekleństwo, stosownie do słów Malachiasza (2, 2): Przeklnę wasze błogosławieństwo; bo też na nich sprawdza się to, co powiedział Ozeasz $(8,11)$ : Pobudował Efraim wiele ołtarzy na obrazę boską i stoły ofiarne służą mu do grzechu. Imię „Efraim” znaczy tu tyle co „wzrastający" i określa stan kapłański, który powienien wzrastać w cnotach i dobrych uczynkach, aby jako wzór obyczajności przyczyniał się do wzrostu ludu Bożego. Lecz dzisiaj niestety cały niemal kler stał się nieprzydatny i bezużyteczny zarówno dla siebie jak i dla ludu, bo, jak powiada prorok, pobudował liczne ołtarze na obrazę boską i zaniedbuje służbę Bożą z lenistwa lub karygodnego występku przez to, że więcej zajmuje się obżarstwem czy rozpustą niż kapłańskimi obowiązkami, albo też niegodnie zachowuje się przy ołtarzu Pańskim. Dlatego znacząco powiada prorok, że taki pobudował sobie liczne ołtarze na obrazę boską, dopuszczając się niegodziwości, i że stoły ofiarne służą mu do grzechu przez poniechanie dobrych uczynków, albowiem w jednym i drugim wypadku przekraczają niekiedy miarę. Dlatego w Księdze Kapłańskiej $(21,21)$ jest o nich mowa w przenośni: żaden z potomków kapłana Aarona, mający jakąś ułomność cielesną, nie zbliży się, aby złożyć ofiarę Panu, ani pokarm swemu Bogu. Wynika z tego jasno, że [występny kapłan] szkodę sobie wyrządza, a nie pomaga.

Miejmyż więc to wszystko na uwadze i unikajmy rozwiązłości jak i próżności, bezczynności oraz zgorszenia, stańmy się bardziej gorliwi w służbie Bożej szczególnie w dzisiejszych czasach, kiedy prawie wszyscy $\mathrm{z}$ nienawiścią odnoszą się do stanu duchownego. I jest być może w tym trochę racji, bo chociaż z przyzwolenia Bożego bardzo wielu z nas wliczony ch zostało do wykonywania służby Bożej, to jednak tylko nieliczni ją sprawują w codziennej ofierze mszy św., inni są zaiste kapłanami $\mathrm{z}$ nazwy, ale w rzeczywistości nie składają żadnej ofiary. Jeżeli jednak zajmowania się służbą Bożą i niewypełniania jej skutecznie bez żadnej przyczyny nie uniemożliwia wyraźna przeszkoda i oczywista ułomność, ograniczająca, jak się zdaje, przyczynę odrzucenia i znamię nienagrodzenia [przez Boga], a jest raczej dowodem moralnego zepsucia, obojętności i uchylania się od niej, miast pobożności, skupienia i gotowości - albowiem nikt nie chciałby mieć sługi, który by nie usługiwał, ani kucharki 
plicium. Nam licet poena ista non sit aeterna, excedit tamen omnem praesentem poenam, immo molestior est quam quidquid homo potest pati in hac vita, ut dicit Augustinus. Sed heu, hoc a pluribus non curatur eo, quod homo ibi non perpetuatur et tandem liberatur. Cum tamen,

5 velut reputo, via illa hoc est tam communis, quod raro aliquis salvandorum ex adultis evadit eius ingressum, unde pro evidenti exemplo de Otthone, benignissimo imperatore, sic scribitur, quod licet in diutino languore eius omni die sacerdotibus dorsum suum tradiderit flagellandum cum tanta devotionis contritione ita, quod crederetur mox evolare

10 aut vix ad horam post mortem purgatorium sustinere ab his, qui eius humilitatem et pietatem cognoverunt eo, quod super ante eius decessum quasi infinitam annonam tempore caristiae diversis monasteriis et pauperibus largiter divisisset. Nihilominus post mortem summo mane apparuit cuidam cognatae suae, quae monasterio virginum praeerat, dicens

15 ad eam:

- Defunctus sum ego et gravissimis poenis crucior in purgatorio. Dirigas ergo quanto citius nuntios ad diversa cenobia et decies mille psalteria legi pro me facias ita, ut ad unumquemque versum addatur „Oratio Dominica" et "Salutatio Angelica" cum certa disciplina. Talibus enim

20 remediis vivens promerui post mortem liberari.

Et his dictis evanuit. Virgo autem negotium iniunctum devote suscepit et perfecit. Post cuius complectionem ipse in aurora in loco priori cum magna claritate rursum sibi apparuit, dicens:

- Gratias reddo tibi et pro me misericordissimo Domino gratias age,

25 quia iam a poenis ereptus ad gloriam transeo sempiternam.

Modo si talis vir, qui tanta fecit pro Deo et tam gravem poenitentiam egit in se ipso, tantam poenam in purgatorio sustinuit et cum tantis precibus liberari promeruit, quis nostrum de se non / timeat et non credat cum quanto desiderio ibi existentes expectent suam liberationem?

1 purgatorii del. post ista.

4 salvatur et est del. post tandem

10 crederetur del. post mortem.

22 hoc autem in del. ante cuius. 
nie przygotowującej potraw - niemniej chcemy być kapłanami, a nie ofiarnikami ani nie rozdającymi sakramentów, ani nie pouczającymi o rzeczach boskich, w ogóle, jeśli tak się godzi powiedzieć, nie słuchającymi nawet o rzeczach świętych, mało czytającymi, a jeszcze mniej działającymi i w konsekwencji nie troszczącymi się o to, jak siebie samych $i$ innych duchowo podbudować. $\mathrm{Na}$ to byśmy się nigdy nie poważyli, zważając na Bożą sprawiedliwość i mając przed oczyma jego pomstę.

Zwróćmy przeto należycie uwagę zwłaszcza na to, czym jest czyściec, jak łatwo doń trafić, ale jak bardzo ciężka jest w nim męka. Bo chociaż kara ta nie jest. wieczna, jednakże przewyższa wszelką karę na ziemi, jest w ogóle przykrzejsza od tego wszystkiego, co człowiek może wycierpieć w tym życiu, jak powiada św. Augustyn. Lecz bardzo wielu niestety nie przejmuje się tym faktem, uważając, że człowiek nie przebywa tam wiecznie i przecież w końcu zostanie zbawiony. Tymczasem, moim zdaniem, droga do czyśćca jest tak bardzo powszechna, iz rzadko komu z dorosłych zbawionych udaje się ją ominąć. Przekonującym tego przykładem jest historia o najłaskawszym cesarzu Ottonie, który choć złożony długotrwałą ciężką chorobą, każdego dnia z tak wielką skruchą i pobożnością nadstawiał swoje plecy pod bicze kapłanów, że ci, którzy znali tę jego pokorę i pobożność, przypuszczali, iż on po śmierci pójdzie od razu do nieba lub najwyżej godzinę będzie przebywać w czyśćcu, gdyż na długo jeszcze przed swoją śmiercią, kiedy nastał głód, szczodrze rozdzielił między klasztory i ubogich nieprzebrane prawie ilości żywności. A jednak [Otton] wkrótce po swojej śmierci ukazał się wczesnym rankiem pewnej swojej krewnej, przełożonej w żeńskim klasztorze, i odezwał się do niej w te słowa:

- Ja umarłem i cierpię najokrutniejsze męki w czyśćcu. Ty zatem możliwie jak najszybciej roześlij posłańców do różnych klasztorów, polecając, aby odmówiono za mnie psałterz dziesięć tysięcy razy, dodając skrupulatnie do każdego wiersza „Modlitwę Pańską” i „Pozdrowienie Anielskie". Jeszcze bowiem za życia uzyskałem to, że będę zbawiony, ale tylko dzięki takiej właśnie pomocy.

To powiedziawszy zniknął. Mniszka zaś z nabożeństwem podjęła złożony na siebie obowiązek i dokładnie się z niego wywiązała. Kiedy go już wykonała, Otton promieniujący wielką jasnością ukazał się jej znowu o świcie w tym samym miejscu, mówiąc:

- Składam ci wyrazy wdzięczności, a teraz ty podziękuj za mnie najmiłosierniejszemu Bogu, ponieważ zostałem już wyrwany z mąk czyśćcowych i zmierzam do wiecznej chwały.

Jeżeli więc taki mąż, pomimo tylu, uczynków złożonych przez siebie dla [chwały] Bożej i nałożenia sobie tak ciężkiej pokuty musiał odbywać w czyśćcu taką karę i dopiero dzięki tylu modlitwom uzyskał zbawienie, 
Ideoque precibus devotis eis omnibus subvenire debemus quantum poterimus et praecipue huic serenissimae Dominae, cuius commemorationem nunc agimus, ex parte cuius licet magnam fiduciam habeamus de eius liberatione et beatificatione, nondum tamen sumus in plena certitu-

5 dine, cum de hoc non habemus determinationem Ecclesiae. Et propterea perpendamus, quod ea, quae circa hanc Ecclesiam et Universitatem nostram egit, non sine spe retributionis fecit.

Ideo videat quisque nostrum, quod sibi hodie debitam recompensationem faciat iuxta perceptorum aestimationem et sui oblationem. Et

10 quilibet revolvat illud Kathonis in mente sua: Accepti beneficii memor esto, et dicat ore illud Jeremiae XXXII ${ }^{\circ}$ [40]: Non desinam 〈eis〉 benefacere. Et simul hodie compleamus opere illud ad Galatas VI ${ }^{\circ}$ [9]: Non deficiamus benefacientes. Et merito, quia si benefacere debeamus inimicis iuxta Mathei $V^{\circ}$ [44]: Benefacite his, qui oderunt vos, multo plus hoc

15 facere debemus amicis et praesertim huic serenissimae Domniae, de qua gloriosa in fama volant, sicut multi non ignorant, praecipue: quo modo ipsa fuit heres huius regni et tota zelatrix fidei et propugnatrix veritatis et iustitiae; similiter quod exstitit speculum castitatis, humilitatis et simplicitatis in victu quam amictu iuxta decentiam sui status quod erat exemplar morum et virtutum et regula vivendi respectu aliarum dominarum; item nutrix pauperum, infirmorum et orphanorum; immo consolatrix maerentium et protectrix viduarum et ecclesiarum et praecipue promotrix sacerdotum et aliorum clericorum et maxime veneratrix maWf. 129 gistrorum, doctorum et aliorum litteratorum et specialissime fundatrix |

25 huius almae Universitatis et Studii Generalis, pro cuius erectione et dotatione, me sciente, vestes et alia sua clenodia testamentaliter legavit et ad hoc suos legittimos executores constituit viros praeclaros, bene notos. Et instantissimis precibus eius erectionem, ante ipsius decessum, tam apud sanctissimum patrem Urbanum quantum ad facultatem theologi-

30 cam, quae nondum erat concessa, quam etiam circa serenissimum principem et dominum, dominum nostrum regem, ipsius consortem et totum eius consilium non sine magnis fatigiis obtinuit.

3 de qua del. sub ex parte.

12 complicat opere illud ad Gala. $\mathrm{VI}^{\circ}$ del. ante simul.

12-13 cf. Gal. 6, 9: Bonum autem facientes non deficiamus.

28 eius del. sub ipsius. 
to któż z nas nie boi się o siebie i nie da wiary temu, z jak wielkim utęsknieniem przebywający w czyśćcu wyczekują swego zbawienia?

Dlatego też winniśmy ile jest w naszej mocy nieść pomoc swymi modlitwami wszystkim zmarłym, a szczególnie tej najjaśniejszej Pani, której pamiątkę śmierci dzisiaj obchodzimy; chociaż żywimy wielką ufność w jej zbawienie i niebieską szczęśliwość, to jednak nie posiadamy jeszcze całkowitej w tym względzie pewności wobec braku stosownego orzeczenia Kościoła. Zważmy jednak, że to, co zdziałała ona dla tego Kościoła i dla naszego Uniwersytetu, uczyniła z nadzieją wzajemnej wdzięczności.

Niechże więc każdy z nas pilnie dzisiaj baczy, aby się jej godnie odwzajemnić wedle własnej ofiarności, doceniwszy to, co od niej otrzymał. Niech każdy rozważy w swym sercu słowa Katona: Pamiętaj o doznanym dobrodziejstwie, i powtórzy za Jeremiaszem $(32,40)$ : Nie przestanę im dobrze czynić. Jednocześnie czynem dowiedźmy dzisiaj słów z listu do Galatów $(6,9)$ : Nie ustawajmy w czynieniu dobra. I słusznie, bo jeśli mamy obowiązek świadczyć dobro nieprzyjaciołom zgodnie ze słowami Mateusza (5, 44): Czyńcie dobrze tym, którzy was nienawidzą, o ileż bardziej winniśmy je świadczyć przyjaciołom, a już szczególnie tej najjaśniejszej Pani, o której, jak to liczni dobrze wiedzą, chwalebna niesie się wieść, jaką to ona była dziedziczką tego królestwa, jak żarliwą wyznawczynią wiary oraz bojowniczką o prawdę i sprawiedliwość; że okazała się również wzorem czystości, pokory i prostoty zarówno w doborze pożywienia jak i strojów, stosownie do godności swego stanu: ponadto, że była przykładem obyczajności i cnót, modelem życia dla innych władczyń; że była wspomożycielką ubogich, chorych i sierot; w ogóle - pocieszycielką pogrążonych w smutku, opiekunką wdów i kościołów, że szczególnymi względami darzyła kapłanów i innych duchownych, że z największym szacunkiem odnosiła się do magistrów, doktorów i osób wykształconych, a już najbardziej że była fundatorką tego sławnego Uniwersytetu i Studium Generalnego, na którego wzniesienie i uposażenie, jak mi wiadomo, ofiarowała w testamencie swoje szaty i inne klejnoty i do jego wykonania wyznaczyła prawnych egzekutorów, mężów przesławnych i dobrze znanych. Nie bez wielu trudności uzyskała wzniesienie Uniwersytetu przed swoją śmiercią, zanosząc nieustanne prośby zarówno do papieża Urbana w sprawie wydziału teologicznego, na który nie było jeszcze zezwolenia, jak również do najjaśniejszego władcy i pana, naszego pana i króla, swego małżonka oraz do całej jego rady. 
Et quia de tam insigni et magnifico dono venit magna gloria huic regno, ideo de ipsa non immerito possum dicere, quod ipsa est gloria huius regni et quod Domino concedente in brevi per suam canonizationem, ad quam instigant varia signa, quibus mirifice continue coruscat,

5 fiet gloria totius mundi ita, quod de ea proportionaliter possum exclamare sicut olim Joachim de Judith post mortem Oleferni fecit ex altis visceribus dicendo:

$\mathrm{Tu}$, Excellentissima Domina, es gloria Cracoviae, laetitia Poloniae et honorificentia populi Tui, 10 quia fecisti viriliter et confortatum est cor tuum.

Eo, quod virtutes amaveris,

ideo manus Domini confortabit Te

et eris benedicta in aeternum.

Quam benedictionem sibi ac nobis omnibus concedat Deus gloriosus 15 per saecula benedictus.

8-13 cf. Idt. 15, 10-11: Tu gloria Ierusalem, tu laetitia Israel, tu honorificentia populi nostri. Quia fecisti viriliter et confortatum est cor tuum, eo quod castitatem amaveris - - ideo et manus Domini confortavite, et ideo eris benedicta in aeternum.

10 quia correxi ex Idt. (cf. supra)] que ms.

\section{NOTA EDYTORSKA}

Franciszek Krzysowicz z Brzegu, obok Stanisława ze Skarbimierza, należał do najwybitniejszych profesorów odnowionego Uniwersytetu w Krakowie na początku XV wieku. Przybył tu w pierwszej grupie praskich mistrzów w r. 1400 i jako magister artium objął wykłady na tym samym wydziale. Jednocześnie kontynuował rozpoczęte jeszcze w Pradze studia teologiczne; jako bakałarz sentencjariusz rozpoczyna ok. r. 1404 wykład kursoryczny, a ok. 1409 w stopniu magistra teologii zostaje dopuszczony do katedry na wydziale teologicznym krakowskiego Studium Generale. Działał na tutejszym uniwersytecie do końca swego życia ( $\dagger 16 \mathrm{X} 1432$ ): był pierwszym dziekanem wydziału sztuk wyzwolonych w półroczu zimowym 1402/3 (ponownie w 1409 r.), natomiast rektorem został w r. $1407^{1}$.

1 Por. J. Fijałek, Studia do dziejów Uniwersytetu Krakowskiego i jego wydziału teologicznego w XV wieku. Kraków 1898, s. 90-94; H. Barycz, Franciszek 2 Brzegu. W: Polski Słownik Biograficzny VII. Kraków 1948-1958, s. 75 n.; M. Markowski, Spis osób dopuszczonych do wykładów $i$ do katedry na wydziale teologii Uniwersytetu Krakowskiego w XV w. ,Materiały i Studia Zakładu Historii Filozofii Starożytnej i Sredniowiecznej”. T. IV: 1965, 175, 217 n. 
Skoro tak ogromny splendor spowił nasze królestwo dzięki temu niezwykłemu i wspaniałemu darowi, przeto nie bez racji mogę o niej powiedzieć, że sama jest chwałą tego królestwa i wkrótce z przyzwolenia Bożego stanie się przez swą kanonizację chwałą całego świata, do czego zachęcają różne znaki, jakimi przedziwnie jaśnieje bez przerwy tak, że parafrazując słowa wypowiedziane niegdyś z głębi serca przez Symeona o Judycie po śmierci Holofernesa, również ja mogę zawołać o naszej Pani:

\author{
Ty, Najjaśniejsza Pani, \\ jesteś chwałą Krakowa, chlubą Polski, dumą twego ludu, \\ ponieważ okazałaś się dzielną, a serce twoje było pełne męstwa. \\ Dlatego, że umiłowałaś szlachetność, \\ przeto umocni Cię ręka Pana \\ i będziesz błogosławioną na wieki.
}

Oby pełen chwały i na wieki błogosławiony Bóg udzielił nam wszystkim tego błogosławieństwa.

Na rocznicę śmierci Królowej Jadwigi Franciszek wygłosił kazanie dwukrotnie; po raz pierwszy prawdopodobnie ok. 1420 r. i w jakieś pięć lat później (ok. 1426), kiedy już działała w Krakowie komisja ustanowiona przez bpa W. Jastrzębca, zajmująca się badaniem cudów Jadwigi ${ }^{2}$.

Kazanie pierwsze - Mortui sumus cum Christo [Rom. 6, 8] - poświęcił Franciszek zawsze aktualnemu problemowi śmierci. Śmierć jest zjawiskiem nieuniknionym (inevitabilis), nieodwolalnym (irrevocabilis), wielorako strasznym (multipliciter horribilis). Przy analizie tych punktów kazania autor dotyka motywu ,tańca śmierci", kiedy przypomina słuchaczom powszechnie znany obraz zabierania przez śmierć ludzi wszystkich stanów, podając przy tym ich precedencję: - - rapiat mors reges, barones et milites, episcopos, canonicos, doctos et indoctos. Te prothemata rozwinął następnie we właściwym kazaniu, gdzie zajmuje się zagadnieniem potrójnej śmierci. W jego ujęciu jest to mors spiritualis vivicationis, mors carnalis reso-

2 Por. M. Kowalczyk, Krakowskie mowy, jw., s. 124, 183, oraz wyżej s. 17. Teksty obu kazań występują w tym samym rękopisie W na f. 112-114v (kazanie wcześniejsze) i f. 124-129 (kazanie z r. 1426). Kazanie drugie poprzedza w tymże rękopisie (f. 120-123) jego wersja wcześniejsza, przeznaczona na uroczystość rocznicową za byłych dobrodziejów krakowskiej uczelni. 
lutionis, mors infernalis cruciationis. W części końcowej uzasadnia potrzebę modlitw w intencji tych zmarłych, którzy za życia ziemskiego wyświadczyli nam dobrodziejstwa, jako że za dobra doczesne godzi się odpłacać dobrami duchowymi. Największym dobroczyńcą Uniwersytetu była właśnie królowa Jadwiga. Dlatego też Franciszek wzywa do modlitwy obecnych na nabożeństwie, i tych wielkich i małych, aby ta najłaskawsza Pani jak najszybciej została uwolniona ze wszelkich krępujących ją jeszcze więzów, a nie daj Boże, aby była jak więzień trzymana (puod absit captiva teneatur) w czyśćcu.

Tekst drugiego kazania przygotował Franciszek najpierw na nabożeństwo żałobne za dobrodziejów Uniwersytetu. Było to prawdopodobnie w r. 1424. W rok lub dwa lata później, w rocznicę śmierci Jadwigi, powtórzył ten sam tekst dodawszy uprzednio na początku i na końcu partie poświęcone Królowej. Z. Budkowa, która to kazanie odkryła, dowiodła jego zależności od kazania Jana Husa na temat Dixit Martha ad Iesum (por. Jan 11, 24), wygłoszonego w rocznicę śmierci cesarza Karola IV w dniu 3 XI 1411 r. Wskazała ona również na rękopis BJ 1628, gdzie pomieszczony jest właśnie tekst tego kazania, a który to kodeks miał w swym ręku także Franciszek. Kazanie Husa jest z kolei zależne od dwóch kazań Jana Wiklefa ${ }^{3}$.

Rocznicowe kazanie o królowej Jadwidze napisane przez Franciszka z Brzegu, jest tekstem niezmiernie ciekawym. Publikowany tekst łaciński i polski wykazuje charakterystyczną konstrukcję i argumentację teologiczną kazania profesora Krakowskiego Uniwersytetu z pierwszej ćwierci XV wieku. Dzięki temu można to kazanie zaliczyć bezspornie do grupy klasycznych tekstów polskiego kaznodziejstwa średniowiecznego. Co prawda, sztuką oratorską Franciszek nie dorównał Stanisławowi ze Skarbimierza, wszelako wykład jego jest rzeczowy, ścisły, logiczny, a mysli poświęcone Królowej przepełnione gorącym uczuciem, wręcz formalnym kultem religijnym, są ożywione szczerym pragnieniem jak najszybszego kanonizowania tej, która jest „,chwałą Krakowa i ozdobą całej Polski”. Franciszek wyraża w swym kazaniu wdzięczność dla Królowej za reaktywowanie Uniwersytetu i pragnienie, by została jego patronką.

Natomiast kler zgromadzony w katedrze, bo tam było głoszone to kazanie, otrzymał wykład na temat teologii pomocy dla zmarłych i teologii kapłaństwa. W pierwszej części kazania autor rozważa zagadnienie potrzeby odprawiania egzekwii za zmarłych. Przyczyny odprawiania egzekwii dzieli na dwie grupy: jedne z nich są godne potępienia czyli fałszywe, drugie - godne pochwały czyli prawdziwe. Do przyczyn fałszywych zalicza: troskę o większą cześć zmarłego, nadmierne wychwalanie jego życia, ciągnięcie doczesnych korzyści z tej okazji. W związku z tym autor krytykuje wystawne stypy, czuwanie połączone z obżarstwem, pijaństwem i gadulstwem. Do przyczyn godnych pochwały zalicza: pamięć o śmierci Chrystusa i o tym, że spowodowały ją nasze grzechy; rozmyślanie nad losem zmarłych, które staje się źródłem poprawy naszego życia; świadczenie pomocy zmarłym. W tym ostatnim punkcie kaznodzieja rozwinął zagadnienie dotyczące nieśmiertelności duszy, istnienia czyśćca, pomocy dla dusz czyśćcowych. Do najskuteczniejszych suffragiów za zmarłych zalicza mszę św. Z nią łączy Franciszek newralgiczny punkt swojego kazania, a mianowicie godność stanu kapłańskiego i wartość aktów sakramentalnych spełnianych przez niegodnych kapłanów. W tym fragmencie kaznodzieja używał bardzo mocnych słów, piętnując postępowanie kleru. Franciszkowi chodziło nie tylko o krytykę kleru, ale uważał, że należało odpowiedzieć na tezy Wiklefa, odrzucającego ortodoksyjną tezę o wartości sakra-

s Por. Z. Kozłowska-Budkowa, Kodeks Mikołaja Tempelfelda. „Sprawozdania PAU”. T. 53: 1952, s. 466-469. 
mentów ex opere operato. Nie mniej dla kleru krakowskiego wezwanie rzucone przez Franciszka - „stańmy się bardziej gorliwi w służbie Bożej szczególnie w dzisiejszych czasach, kiedy prawie wszyscy z nienawiścią odnoszą się do stanu duchownego" - było ostrzeżeniem i przypomnieniem antyklerykalnych wystąpień radykalnych odłamów w czeskim husytyźmie.

Wykład Franciszka na temat teologii kapłaństwa został dostosowany do wymogów statutów synodalnych wieluńsko-kaliskich z roku 1420 . Odpowiednie kanony tych statutów wyjaśniały problem skuteczności sakramentów niezależnie od stanu laski szafarza oraz podawały ,remedia contra haereticos" 4 .

Benedyktyn P. de Vooght analizował kazanie Wiklefa i Husa, wykazując zależność a jednocześnie oryginalność wykładu Husa ${ }^{5}$. Franciszek z Brzegu obficie korzystał, jak już wspomnieliśmy, z tekstu Husa. Tak oto otrzymaliśmy trzy teksty średniowieczne na podobne tematy, opracowane w oparciu o trzy nurty teologiczne tamtych czasów: teologię Wiklefa, teologię Husa i teologię krakowskiej szkoły tenlogicznej, reprezentowanej w tym wypadku przez jej wybitnego przedstawiciela Franciszka z Brzegu.

Kazanie Franciszka z Brzegu odkryła Z. Kozłowska-Budkowa i jego odpis przekazała $w$ formie brulionowej wydawcom do dalszego opracowania. $\mathrm{Na}$ tym miejscu składamy Pani Profesor wyrazy serdecznej podzięki za uprzystępnienie nam tego cennego tekstu, jak też za wszelkie uwagi i sugestie $w$ toku przygotowywania niniejszego upracowania kazań o Królowej Jadwidze.

4 Por. Statuty synodalne wieluńsko-kaliskie Mikolaja Trqby z r. 1420. Kraków $1915-1920-1951$, s. 94-96.

5 Por. P. de Vooght, Hussiana. Louvain 1960, s. $365-378$. 


\section{J A N A IS NERA \\ „KAZANIE O ŚMIERCI KRÓLOWEJ POLAKÓW”}

(Omówienie)

Pierwszy aniwersarz śmierci Królowej Jadwigi wypadł na czas przygotowań do ceremonii otwarcia w r. 1400 odnowionego Uniwersytetu. Inauguracja obejmowała trzy uroczyste akty: 22 lipca Jagiełło ustanawia Kolegium Królewskie; 24 lipca Stanisław ze Skarbimierza, pierwszy rektor odnowionego Studium Generale, dokonuje uroczystego wpisu dostojników i studentów do matrykuły nowej uczelni; 26 lipca król promulguje przywilej fundacyjny Uniwersytetu, po czym biskup krakowski Piotr Wysz wygłasza pierwszy wykład akademicki, a Stanisław ze Skarbimierza słynną mowę inauguracyjną ${ }^{1}$. Te uroczyste i historyczne dni poprzedził 17 lipca aniwersarz zmarłej przed rokiem Królowej. Godziło się bowiem najpierw uczcić pamięć wielkiej fundatorki, a następnie dokonać uroczystego otwarcia Uniwersytetu. Czy tak było istotnie, o tym milczą źródła współczesne.

W rękopisie 4206 (f. 143-145) Biblioteki Narodowej we Wiedniu znajduje się kazanie ${ }^{2} \mathrm{z}$ następującym incipitem:

Incipit sermo ad clerum factus per venerabilem magistrum Ysneri, sacre theologie professorem, de obitu regine Cracovie. Curam illius habe, Luce $\mathrm{X}^{\circ}[35]$, et transumptive in currentis dominice officio.

Quamvis verba ista erunt Samaritani commendantis vulneratum stabulario - -

$\mathrm{Na}$ górnym marginesie k. 143 dopisano ręką późniejszą: Sermo ad clerum magistri Ysneri de obitu regine Polonorum et Johannis archiepiscopi.

Temat kazania: Curam illius habe, pochodzi $z$ ewangelii na 12 niedzielę po Zesłaniu Ducha Sw. W r. 1400 niedziela ta wypadła 12 wrześ-

1 Por. K. Morawski, Historia Uniwersytetu Jagiellońskiego. T. 1, Kraków 1900, 76-79; Z. Kozłowska-Budkowa, Odnowienie Jagiellońskie Uniwersytetu Krakowskiego (1390-1414). W: Dzieje Uniwersytetu Jagiellońskiego w latach 13641764. T. 1, Kraków 1964, 43-47.

2 Tekst kazania ogłosił F. Mencik: Pohřebni řě nad arc. Janem $z$ Jenšteina. W: Zprávy o zasedání Královské České Společnosti Nauk v Praze. R. 1882. Prag 1883 s. 304-309. „Sitzungsberichte der Königlichen Gesellschaft der Wissenchaft in Prag". Autor nie zajmuje się zagadnieniem czasu powstania tego kazania i jego związku z pogrzebem królowej Jadwigi. Wyrazurowane litery $R$ 〈egina〉 $\mathrm{P}\langle$ oloniae〉 zastępuje słowami Reverendissimus Pater. Przed 10 laty miałem w ręku ten rękopis ale nie zwróciłem pilniejszej uwagi na razury, zainteresowany bardziej treścią samego tekstu. Obecnie korzystam z fotokopii tekstu z rękopisu wiedeńskiego i tekstu ogłoszonego przez F. Mencika. 
nia. W tekście kazania królowa Jadwiga jest wymieniana naprzemian $\mathrm{z}$ arcybiskupem praskim Janem z Jensteinu, zmarłym w Rzymie 17 czerwca $1400 \mathrm{r}^{3}$ Autor kazania Jan Isner był pierwszym profesorem teologii na erygowanym w r. 1397 krakowskim wydziale teologicznym ${ }^{4}$. Narzuca się oczywiście pytanie, kiedy Isner wygłosił to kazanie i dlaczego w tekście zestawia owe dwie postacie historyczne. Wobec braku informacji ze źródeł czeskich, które były mi niedostępne, można wysunąć następujące hipotezy. Jan Isner wygłosił kazanie na pierwszym aniwersarzu Królowej, tzn. w lipcu 1400 roku, by w niespełna dwa miesiące później powtórzyć je w Pradze podczas egzekwii arcybiskupa Jana z Jensteinu, dokonawszy uprzednio stosownych zmian i uzupełnień treściowych. Bardziej jednak prawdopodobne jest inne rozwiązanie tej kwestii. Uroczyste, według ceremoniału królewskiego, obrzędy pogrzebowe miały mieć miejsce $\mathrm{w}$ miesiąc po śmierci Jadwigi, czyli w dniu 17 sierpnia $1399 \mathrm{roku}^{5}$. W dzień ten wypadała wówczas dokładnie 12 niedziela po Zesłaniu Ducha Św., a wiemy, że temat Isnerowego kazania został zaczerpnięty właśnie z ewangelii wyznaczonej na tę niedzielę. Wynikałoby z tego, że pierwszą wersję owego kazania poświęconą wyłącznie osobie zmarlej Królowej, opracował Isner w roku 1399. W roku następnym w Pradze wykorzystał gotowy tekst modyfikując go nieznacznie, stosownie do zmienionych okoliczności. Nie posiadamy jednak pierwszej wersji omawianego kazania. Tekst obecny łączono też z kolekcją kazań de sanctis Jana Szczekny ${ }^{6}$.

W treści tego kazania Jan Isner rozważa zagadnienie śmierci, rozpatrywane według następujących dyspozycji: mors naturae, mors culpae, mors gratiae. Wzmianki o Jadwidze są bardzo ogólnikowe i w zasadzie nie wnoszą żadnych nowych treści. Oto dwa przykłady z f. 143:

Cogitanti michi de illus reginae Poloniae morte et obitu temporali magis libet flere, quam aliud dicere - -

Et ideo hanc reginam Poloniae in magna dignitate constitutam de medio nostri abstulit, quamvis tamen in morte mansura non sit, sed a morte resurrecturus - -

3 Literaturę o arcybiskupie i jego twórczość piśmienniczą podaje J. Třiska: Přispěvky $k$ stř́ édověké literárni universitě. W: Acta Universitatis Carolinae Historia Universitatis Carolinae Pragensis. T. 10: 1969 fasc. 1 s. $27-23$.

4 Por. J. Zathey, Jan Isner. W: Polski Słownik Biograficzny. T. 10 s. 434436; Ioannis Isneri Expositio Missae. Ed. R. M. Zawadzki. W: Textus et Studia Fiistoriam Theologiae in Polonia Excultae Spectantia. Vol. 1: 1971, $13 \mathrm{nn}$.

5 Por. K. Szajnocha, Jadwiga $i$ Jagiełło. T. 4, Lwów 1861, 144. Autor podaje, że kazanie w dniu 17 sierpnia wygłosił Stanisław ze Skarbimierza.

6 Por. Schwarzenberg, Katalog der kroatischen, polnischen und tschechischen Handschriften der Österreichische Nationalbibliothek, Wien 1972, 120; J. Wolny, M. Markowski, Z. Kuksewicz, Polonica w średniowiecznych rękopisach bibliotek monachijskich, Wrocław 1969, 115-119. 
[STANISLAUS DE SCARBIMIRIA]

\section{SERMO LATINUS \\ IN EXEQUIIS DOMINAE HEDVIGIS REGINAE POLONIAE \\ (fragmentum)}

$J^{2} f .354 v$ $J^{3} f .205 v$

$J^{2} f .355$

20

$J^{3} f .206$

- Miseremini mei saltem vos amici mei [Iob 19, 21], quibus humanitatem ostendi, quibus beneficia impendi, quos de manu tyrannorum eripui, quibus utcumque potui affui praesidio vel favore. Sed silent interdum amici, obmutescunt proximi, obturant aures vicini et noti. Nam fortasse qui a recolendae memoriae domina HEDVIGI, regina

10 Poloniae, mille talenta recepit, scrupulum unum vel denarium pro remedio animae suae, si et in quantum hactenus in purgatorio est detenta, dare parvipendit, licet opera ipsius vociferent in capitulis, sonent in castris et villis, refulgeant in altaribus, reluceant in ornatibus et praesertim 〈in〉 insigni clenodio Universitatis nostrae, per quod affectus

15 naturalis amicitiae, quo nobis velut pia mater et patrona coniuncta fuerat, apparet intimitas - - Alma Univeritas Studii Generalis Cracoviensis aperit viscera humanitatis et clementiae grata sibi collatae beneficientiae - - I Ipsa namque suffulta Dei gratia, quae non generis nobilitate sed virtutum comparatur — - iam fulgens pretiosis lapidibus, videlicet diversis doctorum magistrorum, baccalariorum, nobilium scholarium et studentium, | variarum etiam professionum et nationum margaritis, agit in quadam votorum unione anniversarium beatae memoriae HEDVIGIS, matris et fundatricis suae - - Orat nostra Univer-

* Hoc fragmentum sermonis, anno ut videtur 1401 a Stanislao de Scarbimira conscripti, a M. Kowalczyk (op. cit. p. 130) laudatum est. Integralem vero textum praebent mss.: $\mathrm{J}^{2}$ (f. $352 \mathrm{r}-356 \mathrm{r}$ ), $\mathrm{J}^{3}$ (f. $203 \mathrm{v}-206 \mathrm{v}$ ), W (f. $57 \mathrm{r}-61 \mathrm{v}$ ).

1-3 Eandem inscriptionem sermonis sine auctoris nomine indicato mss. proferunt.

14 in insigni clenodio Z. Kozłowska-Budkowa, in signo clenodii J. Wolny, insigne clenodium mss.

17 humanitatis $J^{*}, W$ pietatis $J^{2}$. 
V

STA I I E A W ze SKARBIMIER Z A

\section{KAZANIE ŁACIŃSKIE \\ NA EGZEKWIACH JADWIGI KRÓLOWEJ POLSKI}

(fragment)

- Zlitujcie się nade mną przynajmniej wy przyjaciele moi (por. Job 19, 21), którym okazałem człowieczeństwo, którym wyświadczyłem dobrodziejstwa, których wyrwałem z rąk tyrańskich, których jak tylko mogłem otaczałem opieką i życzliwością. Ale przyjaciele czasem milczą, najbliżsi tracą mowę, sąsiedzi i znajomi zatykają sobie uszy. Niekiedy bowiem ten, kto otrzymał tysiąc talentów od z czcią wspominanej pani naszej JADWIGI, królowej Polski, nie dba o to, by bodaj miedziaka, bodaj jednego denara ofiarować za spokój jej duszy, o ile w ogóle jest ona jeszcze zatrzymywana w czyśćcu, gdy tymczasem jej czyny odbijają się głośnym echem w kapitułach, rozbrzmiewają sławą po miastach i wsiach, jaśnieją w ołtarzach, błyszczą w ornatach, a zwałszcza w tym wspaniałym klejnocie, jakim jest nasz Uniwersytet; w nim to ujawniło się jej najintymniejsze uczucie naturalnej przyjaźni, które złączyło ją z nami, jako pobożną matkę i opiekunkę - - Chwalebna akademicka społeczność krakowskiego Studium Generale, wdzięczna za doznane dobrodziejstwa, z głęboką życzliwością i łaskawością otwiera swe podwoje - - Ta właśnie [społeczność] umocniona łaską Bożą, której nie zdobywa się dzięki szlachetności rodu lecz cnót - - jaśniejąc obecnie jakby drogocennymi klejnotami w osobach różnych doktorów, magistrów, bakałarzy, szlacheckich scholarów i studentów rozmaitych profesji i narodowości, złączona jakimś wspólnym pragnieniem, obchodzi pamiątkę śmierci ś.p. JADWIGI, matki i fundatorki swojej - - 
sitas ac orando praelatos ad orandum etiam excitat, religiosos movet, nobilibus exemplificat, maiores invitat, minoribus rationabiliter imperat - - Orat autem pro fidelibus, quemadmodum pro christianissima principe domina HEDVIGI ac Cazymiro et aliis requibus Poloniae, pro-

5 fessoribus fidei catholicae nec non et universis baptizatis, etiam de quorum salute dubitatur - -

NOTA EDYTORSKA

Data wygłoszenia kazania nie jest pewna. M. Kowalczykówna, uważając, że kazanie musiało być wygłoszone w rocznicę śmierci Jadwigi, tzn. 17 lipca, stwierdziła, iż temat kazania - Misereor super turbam (Mt. 8, 2) - został wyjęty z ewangelii przeznaczonej na 7 niedzielę po św. Trójcy. Otóż niedziela ta przypadała dokładnie w drugą rocznicę śmierci Jadwigi, tzn. 17 lipca 1401 roku ${ }^{1}$.

Treścią kazania jest zagadnienie obowiązku niesienia pomocy duszom zmarłych, przebywającym w czyśćcu. Stanisław rozważa trzy okoliczności, które pobudzają wiernych do wypełnienia tego religijnego obowiązku: (1) surowość kar czyśćcowych, nękających dusze tam przebywające, (2) niemożność samodzielnego bronienia się dusz przed sądem Bożym, (3) naturalne uczucie przyjaźni, jakim darzymy zmarłych. W cytowanych słowach Chrystusa autor znajduje uzasadnienie modlitwy za Jadwigę, królów polskich i wszystkich przebywających w czyśćcu. Co do Jadwigi, to powątpiewa czy ona w ogóle tam przebywa (,si et in quantum hactenus in purgatorio est detenta").

1 Por. M. Kowalczyk, jw. s. 120. 
Modli się nasz Uniwersytet i tym zamodleniem pobudza do modlitwy także dostojników kościelnych, nakłania zakonników, szlachcie podsuwa jej wzór, możnych zachęca, maluczkim roztropnie tę modlitwę nakazuje - - Bo jest to modlitwa za wiernych, jako to za najbardziej chrześcijańską władczynię, panią [naszą] JADWIGE i za [króla] Kazimierza [Wielkiego] i za innych królów Polski, za nauczycieli wiary katolickiej i za wszystkich ochrzczonych, a nawet za tych, których zbawienie jest wątpliwe - -

Bardzo charakterystyczną (w r. 1401) jest wzmianka o obowiązku modlitwy za Kazimierza Wielkiego, o którego wiekopomnej zasłudze Uniwersytet Krakowski w czasach Jagiełły dość szybko zapomniał. Modus et ordo petendi pro benefactoribus z r. 1408 umieszcza Jadwigę na pierwszym miejscu pośród imion zmarłych dobrodziejów Uniwersytetu ${ }^{2}$. Inną znamienną cechą kazania jest ta przedziwna troska, jaka przebija w słowach Stanisława, kiedy mówi o krakowskiej uczelni. Wyraża się o niej z ogromnym pietyzmem jakby czuł, że grozi jej jakieś niebezpieczeństwo. Istotnie. Byt Uniwersytetu $w$ pierwszym dziesięcioleciu jego istnienia został generalnie zagrożony. Wystarczy tylko sięgnąć do Album Studiosorum, by przekonać się, że po rekordowym naborze studentów w r. 1400, kiedy to wpisało się 203 scholarów, w latach następnych liczba ta waha się między 97 a 35 nowo przyjętych. Nadto, zbliżająca się wojna z Zakonem krzyżackim i założenie uniwersystetu w Lipsku spowodowały odpływ nie tylko studentów ale i profesorów. Wówczas to Stanisław powie w jednym ze swoich kazań, że „diabeł przesiewa mistrzów jak przenicę" 3. Widocznie już rok 1401 był pod tym względem niejako symptomatyczny, skoro Skarbimierczyk tak gwałtownie podkreśla wielkość i znaczenie krakowskiej Almae Matris.

2 Por. Z. Kozłowska-Budkowa, Odnowienie, jw. s. 50.

3 Por. tamże s. 55. 


\section{VI \\ I O A NES ELGOT \\ S E R M O I S \\ IN RECOMMENDATIONE HEDVIGIS REGINAE FRAGMENTUM}

5 - - Quod animadvertens princeps serenissima non minus meritis quam sanguine generosa HEDVIGIS piae recordationis, olim regina Poloniae, dum in huius labentis saeculi stadio decurreret, pervigili cura studuit sic vitam naturae vivere, ut vita gratiae vegetata ad vitam interminabilis gloriae posset pervenire. Ipsa enimvero, prout fide dignorum per-

10 sonant testimonia, bonarum actionum varietate, velut quibusdam radiis micantibus in conspectu singulorum fulgurabat. Mater enim fuit pauperum, tutrix orphanorum, fundatrix studiorum, refugium oppressorum et vera maerentium consolatrix. Fuit pes claudo et oculus caeco. Et eatenus quasi balsamum aromatisans in medio populi odorem dedit et ma-

15 nus suae myrrham distillaverunt, quae et nostris temporibus fragrare non desistit. Quapropter et nos amore supernorum afflati curramus in odorem horum unguentorum et in hac dierum malitia abnegantes impietatem, non peccato sed Deo vivere satagamus, quatenus vitae aeternae fructum tandem habeamus, quam nobis concedet Deus per saecula

20 benedictus. Amen.

* Textum sermonis, circiter annum 1428 ab auctore conscriptum, primum edidit M. Szafrankiewicz: Jana Elgota mowa w rocznicę śmierci królowej Jadwigi, „Acta Mediaevalia” 1 (1973), p. 107-133. Cf. MI. Kowalczyk, op. cit. p. 126, 185.

\section{NOTA EDYTORSKA}

Autor kazania, Jan Elgot, urodzony ok. roku 1400 na Sląsku odbył studia uniwersyteckie $w$ Krakowie, gdzie też ok. r. 1427 jako uczeń Stanisława ze Skarbimierza uzyskał tytuł doktora dekretów. Był jednym z najbliższych współpracowników biskupa Oleśnickiego i z tej racji brał żywy udział w życiu Uniwersytetu, Kościoła i państwa ${ }^{1}$.

Sprawą królowej Jadwigi zajmował się z urzędu przynajmniej dwukrotnie. Po raz pierwszy $w$ roku 1426, kiedy to wraz $z$ innymi profesorami krakowskimi został powolany przez abpa Jastrzębca do komisji, spisującej i badającej cuda dziejące się przy grobie Królowej ${ }^{2}$. Drugi raz zabiegał o jej kanonizację w Rzymie.

1 Dwukrotnie pełnił funkcję rektora UJ - 1427, 1437/8. W roku 1431 brał udział w dyspucie z delegacją husycką. Był członkiem kapituły krakowskiej, a w latach 1437-1439 i 1441-1452 wikariuszem generalnym diecezji. W r. 1441 delegowany przez Oleśnickiego wyjeżdża jako polski delegat na sobór w Bazylei. gdzie wygłasza trzy wspaniałe mowy. Szczególną wartość posiada druga mowa o władzy papieża jako następcy Chrystusa. Na dworze wawelskim pełnił Elgot funkcję spowiednika królowej Zofii, a być może był także nadwornym kaznodzieją.

2 Por. wyżej s. 17. 


\section{VI \\ J A N ELGOT \\ FRAGMENT KAZANIA \\ W ROCZNICE SMIERCI KROLOWEJ JADWIGI}

- Najdostojniejsza pani, szlachetna nie mniej z powodu zasług jak dzięki krwi, świętej pamięci JADWIGA, ongiś królowa Polski, kiedy jeszcze stąpała po tym grzesznym świecie, starała się - mając to wszystko na uwadze - z czujną troskliwością tak przeżyć swoje przyrodzone życie, aby umocniwszy [w sobie] życie laski móc dojść do życia nieskończonej chwały. Bo też ona, jak potwierdzają to wiarogodne świadectwa, promieniując różnorodnością dobrych uczynków, jaśniała w oczach wszystkich jakby blaskiem niezwykłym. Była bowiem matką ubogich, opiekunką sierot, założycielką wszechnicy naukowej, ucieczką uciśnionych i prawdziwą pocieszycielką strapionych. Była stopą chromego i okiem ślepca. I dotąd jako wonny balsam rozchodzi się jej zapach wśród ludu, a olejek mirrowy, który spłynął z jej dłoni, nie przestał pachnąć jeszcze w naszych czasach. Dlatego i my, ożywieni miłością do niebios, biegnijmy za wonią tych pachnideł i wyrzekając się bezbożności w zdradliwej chwili, starajmy się żyć nie dla grzechu lecz dla Boga, abyśmy w końcu otrzymali owoc wiecznego żywota, którego udzieli nam łaskawie Bóg przez wieki błogosławiony. Amen.

gdzie wraz z J. Dlugoszem i M. Bonfilim przebywał w r. 1450 z okazji uroczystości roku Jubileuszowego. Stąd udali się następnie do Ziemi Swiętej. Elgot zmarł w Krakowie w r. 1452 w czasie zarazy morowej ${ }^{3}$.

Kazanie na rocznicę śmierci królowej Jadwigi wygłosił prawdopodobnie w r. 1428 przed akademickim audytorium. Treść kazania rozpada się na trzy części 4 Najpierw daje Elgot wykład na temat wszechobecności Boga w działaniu ludzkim. Przy tym porusza zagadnienie łaski Bożej. Z kolei przechodzi do krytyki życia współczesnych chrześcijan, a szczególnie stanu duchownego. Temu ostatniemu wytyka zbytnią troskę o dobra doczesne i zabieganie o godności duchowne. W lapidarnym stwierdzeniu przestrzega kler, powiadając: Takilud, jaki kapłan. Apeluje więc do społeczności duchownej Uniwersytetu, przylaczając słowa z I listu św. Piotra: Jesteście rodzajem wybranym, królewskim kaplaństwem, narodem i ludem nabytym (1 Pt 2, 9). Część końcową kazania obejmuje krótki wykład o sensie dobrego życia, na które składa się życie natury, życie łaski, wreszcie - życie chwały. Te końcowe rozważania związały treść kazania z osobą królowej Jadwigi. Ona bowiem wspierała życie natury życiem łaski, a to pozwoliło jej dojść do życia chwały. W zakończeniu Elgot w krótkim ale urzekającym i subtelnie naszkicowanym obrazie nazywa niezapomnianą Królowę „stopą chromego i okiem ślepca”.

3 Por. H. Barycz, Jan Elgot. W: Polski Słownik Biograficzny, t. VI, 227 n.; M. Szafarkiewicz, Jana Elgota mowa w rocznicę śmierci Królowej Jadwigi. „Acta Mediaevalia" 1: 1973, 107-109.

${ }_{4}$ Zwięzłą charakterystykę treści kazania daje M. Szafarkiewicz, jw. s. 110-115.

Analecta - 6 


\title{
VII
}

\author{
PAULUS de ZATOR \\ S E R M O N I S \\ „EADEM QUIPPE MENSURA” [Lc. 6, 38] \\ FRAGMENTUM
}

$\mathbf{J}_{\mathbf{J}^{\mathbf{f}} f \cdot 100}$ - 82 - Cum igitur horrendum iudicium fiat his, qui praesunt (Sap. 6) restat, ut quilibet diligenter suo invigilet officio attendens, quoniam divinae recompensationis copiosa est aequitas. Haec operose in cordis tabula olim serenissima princeps annotavit et ideo velut stella matutina actionum bonarum varietate, velut quibusdam radiis micantibus in con10 spectu singulorum fulgurabat. Erat enim reverentia pontificum, recursus sacerdotum, benefactrix magistrorum, fundatrix Studiorum, alatrix viduarum, consolatrix orphanorum, clipeus pauperum, refugium oppressorum, interventrix expulsorum, pia Martha infirmorum et Magdalena (!) contemplatorum. Hoc ipsum et figurae cereae, supra tumulum eius de-

15 pendentes liquide demonstrant et velut signa effectuum vitae eius pristinae indicant sanctitatem - -

* Inscriptiones sermonis desunt. Nomen auctoris ab Ioanne Cantio, librario codiics $\mathrm{J}^{5}$, in fine textus sermonis allatum. Paulus hunc sermonem circiter annum 1430 pronuntiavit, quod mihi valde probabile videtur - cf. R. M. Zawadzki, Stan badañ nad życiem i spuścizna rękopiśmienna św. Jana z Kęt, ,Analecta Cracoviensia". T. 5: 1973 s. 33, 36, 43. Fragmentum supra transcriptum invenies etiam apud M. Kowalczyk (op. cit. p. 136). Textus integralis in $\mathrm{ms}$. $\mathrm{J}^{4}$ (f. $96 \mathrm{r}-100 \mathrm{r}$ ) et $\mathrm{J}^{5}$ (f. $74 \mathrm{r}-$ 82 r) exstat.

5 cum - praesunt, cf. Sap. 6, 6: quoniam iudicium durissimum his qui praesunt fiet.

9 bonorum $J^{4}$

10 recursus] incursus $J^{4} J^{5}$, succursus $M$. Kowalczyk, sed. cf. (supra p. 24, 24) sermonem Stanislai de Scarbimiria, ex quo hanc lectionem deprompsi.

\section{NOTA EDYTORSKA}

W r. 1423 magister artium Paweł z Zatora obejmował stanowisko kaznodziei w katedrze krakowskiej, ufundowane przez Jana Szafrańca ${ }^{1}$. Studiował wówczas jeszcze prawo kościelne pod kierunkiem Jana Elgota, który w stosownym czasie wygłosił mowy przy nadaniu Pawłowi stopnia licencjata, bakałarza i doktora praw ${ }^{2}$.

1 W r. 1420 król Władysław Jagiełło zwrócił się do papieża Marcina V w sprawie fundacji urzędu stałego kaznodziei w katedrze krakowskiej. Na uposażenie tego kaznodziei miały być przeznaczone dochody $\mathrm{z}$ beneficjum dziekana kapituły katedralnej - Jana Szafrańca. Prawdopodobnie fundacja została zrealizowana tylko częściowo - por. Liber cancellariae Stanislai Ciolek. Ed. J. Caro. Wien 1871-1874, $\mathrm{nr} 84$.

2 Por. M. Kowalczyk, Krakowskie mowy, jw. s. 175 n. 


\section{VII}

PAWEE Z ZATORA

FRAGMENT KAZANIA

„EADEM QUIPPE MENSURA” [モk. 6, 38]

Skoro zatem odbędzie się straszny sąd nad panującymi (por. Mdr. 6, 6), nikomu nie pozostaje nic innego jak gorliwie pilnować swego obowiązku, bacząc iż obfita jest sprawiedliwość wynagrodzenia Bożego. Tę myśl głęboko ongiś wyryła w sercu [swoim] najjaśniejsza pani [JADWIGA] i dlatego jak gwiazda zaranna błyszczącymi promieniami, tak ona lśniła różnorodnością dobrych uczynków. Była bowiem pełna szacunku dla dostojników Kościoła, była ucieczką kapłanów, dobrodziejką magistrów, założycielką wszechnicy naukowej, wspomożycielką wdów, pocieszycielką sierot, tarczą ubogich, schronieniem uciśnionych, pośredniczką wypędzonych, pobożną Martą cierpiących i Magdaleną (!) rozmyślających. Tego właśnie dowodzą w sposób naoczny również figurki woskowe, zawieszone nad jej grobem, i jako znaki, obrazujące skutki jej przeszłego życia, świadczą za jej świętością - -

Kazanie na rocznicę śmierci Królowej napisał Paweł już po uzyskaniu doktoratu z prawa, tzn. ok. 1430 roku. Tematem kazania było zagadnienie przemijania życia ziemskiego. Treść kazania, ozdobiona licznymi metaforami w bogatej szacie słownej, posiada już wyraźne cechy retoryki humanistycznej. W części poświęconej Królowej autor przytacza świadectwa kultu, rozwijającego się przy grobie Jadwigi w katedrze krakowskiej. Tak więc wypowiedź Pawła posiada walor dokumentu, rejestrującego opinię i vox populi o świętości Królowej ${ }^{3}$. W kazaniu tym autor wykazał znaczny talent oratorski. Nie dziwi przeto zapiska zamieszczona w kalendarzu kapitulnym pod datą śmierci Pawła z Zatora, poświadczająca, że w kazaniach polskich do ludu nie miał on sobie równego ${ }^{4}$.

3 Szczególna wartość i autentyzm słów Pawła o Jadwidze wynika stąd, że był on przecież członkiem komisji powołanej w r. 1426 przez abpa W. Jastrzębca dla zbadania cudów dziejących się za sprawą Jadwigi - por. wyżej s. 17.

4 Por. Monumenta Poloniae Historica. T. II. Warszawa 1961 (1872), s. 939; K. Morawski, Historia Uniwersytetu Krakowskiego. T. I. Kraków 1900, s. 289-291. 


\title{
VIII
}

\author{
S E R M O N I S \\ PRO DEFUNCTIS FRAGMENTUM
}

$J^{1}$ f. 164 - - His profecto sagaci consideratione attentis olim seremissima prin-

${ }^{J} f .7 v$ ceps HEDVIGIS, regina Poloniae, nobilis genere sed fide nobilior, dum

5 in humanis ageret, quamvis iuxta genus saeculi divitiis et honoribus afflueret, his tamen perituris vitiose non adhaerebat, sed amore sui Conditoris et desiderdio supernorum accensa diem mortis bonis studebat moribus praevenire. Clara nempe sunt testimonia, quod erat auctrix assidua cultuum divinorum, protectrix Ecclesiae, ministra iustitiae et

10 pedisequa omnium virtutum humilis et benigna mater omnium oppressorum - -

* Ille „Sermo pro defunctis” vel „Collatio”, quae inscriptiones in mss. occurrunt, $\mathrm{ab}$ ignoto auctore circiter annum 1443 conscriptus est. Fragmentum textus supra transcriptum a M. Kowalczyk (op. cit. p. 135 sq.) laudatur. Integralem vero sermonis textum ms. $J^{1}$ (f. $162 \mathrm{r}-164 \mathrm{r}$ ) et $J^{4}(\mathrm{f} .5 \mathrm{v}-7 \mathrm{v})$ praebent.

4 regina Hedvigis Polonie $J^{4}$

8 erat om. $J^{4}$

10 et humilis et $J^{4}$ 
VIII

FRAGMENT KAZANIA O ZMAREYCH

- Zaiste, rozważywszy to niegdyś z wytężoną uwagą najjaśniejsza pani, królowa Polski JADWIGA, której szlachetność wiary przewyższała szlachetność rodową, przecież kiedy jeszcze żyła wśród ludzi, opływając w bogactwa i zaszczyty właściwe tamtemu wiekowi, nie lgnęła jednak pochopnie do tych rzeczy niosących zgubę, ale rozpalona miłością do swego Stwórcy i z tęsknoty za niebem starała się poprzedzić dzień swej śmierci dobrymi obyczajami. Istnieją bowiem niezbite świadectwa, że była wytrwałą pomnożycielką kultu Bożego, opiekunką Kościoła, szafarką sprawiedliwości, pokorną służebnicą wszelkich cnót i łaskawą matką uciśnionych - - 


\section{U W A G KON COWE}

Z przedstawionych powyżej kazań krakowskich profesorów z pierwszej połowy XV stulecia wyłania się nowy, niemal nieznany dotąd obraz królowej Jadwigi. Dokumenty, dyplomy, kroniki przekazały nam majestatyczny konterfekt królowej Polski: Jadwiga wydająca ustawy, prowadząca narady polityczne, wysyłająca korespondencję dyplomatyczną, przyjmująca posłów zagranicznych itp. $\mathrm{Z}$ kolei $\mathrm{w}$ rachunkach zamku królewskiego ukazuje się Jadwiga jako dama dworu, która urządza przyjęcia, podróżuje, poluje. $\mathrm{Na}$ podstawie zaś zapisów, legatów, fundacji przekonujemy się jak była prawdziwie chrześcijańskiego miłosierdzia i gorliwą czcicielką kultu Bożego; ona, królowa, opiekuje się chorymi i biednymi, zakłada szpitale, wspomaga zakony, funduje ołtarze, eryguje kolegium psałterzystów. Wreszcie erekcja wydziału teologicznego, zapis klejnotów na odnowienie Uniwersytetu Krakowskiego, zgromadzenie biblioteki, Psałterz floriański - to dzieła Jadwigi ,,intelektualnej", rozczytanej w Piśmie św., traktatach teologicznych.

Ale w kazaniach Jadwiga została przekazana potomności jako ta, którą spontanicznym kultem religijnym i czcią otoczyli pospołu profesorowie, studenci i mieszczanie krakowscy. Jest to już Jadwiga wiary religijnej i przeżyć religijnych, jakże nieuchwytnych w najbardziej dokładnych kronikach i dokumentach politycznych. Ta Jadwiga wiary pojawiła się wkrótce po śmierci w pamięci najwybitniejszych profesorów krakowskich, którzy będąc świadkami jej niezwykłego życia pozostawili nam o nim tak autentyczne i wzruszające świadectwo.

Lektura publikowanych kazań pozwala nam poznać również tytuły, jakimi mistrzowie krakowscy obdarzali Jadwigę oraz w jakich słowach podnosili wspaniałe przymioty jej duszy i ciała. Listę tych epitetów można by zestawić w trzech grupach, zaliczając do pierwszej grupy głównie tytuły moralne, do drugiej tytuły podkreślające jej zasługi dla Polski, a szczególnie dla Uniwersytetu, wreszcie do trzeciej - tytuły charakteryzujące jej wiarę i stosunek do Kościoła.

Najwięcej tytułów określa Jadwigę jako człowieka. Jest więc ona przede wszystkim: nobilis genere sed nobilior moribus (fide), profunde humilis licet multum sublimis, sagax in consilio, affabilis affatu, decora vultu, non iracunda, non verbosa, non rixosa; exemplar morum et virtutum, regula vivendi, sanctitats vitae, pedisequa omnium virtutum, speculum castitatis et humilitatis et simplicitatis in victu; pia mater, humilis et benigna mater; consolatrix maerentium, relevamen, refugium, mater omnium oppressorum, interventrix expulsorum, tutrix orphanorum; mater, clipeus, consolatio, nutrix pauperum, infirmorum, orphanorum; alatrix, benefactrix, protectrix, refrigerium viduarum; pia 
Martha infirmorum et Maria contemplatorum, pes claudo et oculus caeco; ministra iustitiae, propugnatrix veritatis et iustitiae; stella matutina, speciale clenodium.

Ze względu na jej zasługi dla Uniwersytetu i całego narodu polskiego nazywano ją: causa erectionis et fundationis sanctae Universitatis Cracoviensis, instigatrix et fundatrix nostrae Universitatis, fundatrix Studiorum, benefactrix magistrorum, veneratrix magistrorum, doctorum et aliorum litteratorum; nostra domina, mater, benefactrix; gloria Cracoviae, decus Regni Poloniae, laetitia Poloniae, gloria huius Regni, benefactrix totius Coronae Regni Poloniae, honorificentia populi sui; firmamentum pacis, gloria totius mundi.

Jej głęboka wiara i przywiązanie do Kościoła zyskały jej miano: zelatrix fidei, auctrix assidua cultorum divinorum, testamentum et tutela divinae legis; protectrix Ecclesiae, benefactrix et promotrix istius Ecclesiae (sc. Cracoviensis); mater spiritualium, promotrix et recursus sacerdotum, revenerentia pontificum.

Należy jednak pamiętać, że Jadwiga z kazań profesorskich nie jest inna od Jadwigi historycznej. To właśnie Jadwigę historyczną sławił jako Swiętą vox professorum, do czego najlepiej nadawały się kazania. Dzięki nim utrzymywano w pamięci potomnych świadectwo o jej świątobliwym życiu i rozbudzano religijny kult wokół sławnej Królowej.

Katalog wymienionych tytułów rysuje sylwetkę duchową Jadwigi. W tym miejscu rodzi się pytanie: według modelu jakiej duchowości była kształtowana psychika młodej Królowej. Wokół tego zagadnienia narosła już obszerna literatura i wysuwano dotąd wiele rozmaitych koncepcji ${ }^{1}$. Podstawowym źródłem do poznania formacji duchowej Jadwigi jest przede wszystkim traktat Henryka Bitterfelda z Brzegu - De vita contemplativa et vita activa, napisany specjalnie dla Królowej. Dotąd nie powstało żadne studium na temat tego traktatu, a tylko wypowiadano dość luźne, czasem sprzeczne na jego temat opinie, pozbawione wnikliwego zbadania problemu na tle duchowości średniowiecznej. Znaczenie traktatu Bitterfelda trafnie oceniła A. Strzelecka, pisząc, że ,jest to pewnego rodzaju filozoficzno-teologiczne vademecum, wskazujące sposoby, by pogodzić czynne życie na królewskim stanowisku z kontemplacją" 2. Natomiast autor monografii o psałterzu floriańskim nie widział tak wielkiego znaczenia dzieła Bitterfelda w rozwoju duchowym Jadwigi ${ }^{3}$. Ostatnio ponownie zwrócono uwagę na wspomniany traktat $i$ jego

1 Por. A. Strzelecka, Jadwiga królowa. W: Hagiografia polska. T. 1. Poznań 1971, 485-523.

2 A. Strzelecka, O królowej Jadwidze. Studia i przyczynki. „Archiwum Towarzystwa Naukowego we Lwowie". Dział II. T. 14: 1933, 141.

3 Por. M. Gębarowicz, Psatterz floriański i jego geneza. Wrocław 1965, 85-126. 
miejsce $\mathrm{w}$ biografii Jadwigi ${ }^{4}$. W moim przekonaniu Henryk Bitterfeld posłużył się ewangeliczną przypowieścią o Marii i Marcie (por. Łuk. 10, 38-42), aby rozwinąć temat o jedności życia kontemplacyjnego z życiem czynnym, temat - jakże nierozłącznie złączony $\mathrm{z}$ historią chrześcijańskiej duchowości i postawą chrześcijanina wobec rzeczywistości ziemskiej. W dziejach interpretacji modelu vitae contemplativae i vitae activae znane są rozwiązania różnych teologów. We wspomnianym wykładzie wysunąłem hipotezę o zależności interpretacji modelu vita activa et vita contemplativa w ujęciu Henryka Bitterfelda od interpretacji mistyków niemieckich tego czasu, a mianowicie mistrza Eckharda i Jana Taulera. Według nich istnieje jedność między życiem kontemplacyjnym a życiem czynnym, ale życie czynne otrzymuje najwyższą wartość 5 . Hipoteza o zależności traktatu Bitterfelda od doktryny mistyków niemieckich XIV wieku została we wspomnianym wykładzie mocno wyeksponowana, ale istnieją świadectwa wskazujące także na wpływ doktryny św. Tomasza z Akwinu, wyłożonej w secunda secundae Summy teologicznej (q. 182).

Traktat Bitterfelda składa się z listu dedykacyjnego, po którym następuje część o kontemplacji, a w drugiej części autor zajmuje się zagadnieniem życia czynnego.

W liście dedykacyjnym do Jadwigi mówi o jedności, harmonii i potrzebie życia kontemplacyjnego i życia aktywnego jako drogowskazu w życiu duchowym i działalności Królowej. Bitterfeld powiada m. in., że „godność królewska zmusza do brania udziału w życiu czynnym, każe tylu nędzom ubogich ludzi codziennie przynosić ulgę, tyle spornych spraw załatwiać, tylu groźnym niebezpieczeństwom zapobiegać, troszczyć się pieczołowicie o tak wielkie królestwo; mało czasu pozostawałoby na ucieczkę do kontemplacji. Jeśli by tylko w ten sposób zajmować się Bogiem, to przecież mogłyby powstać pozory zaniedbywania miłości bliźniego i gubienia własnego narodu, a za tę cenę Bóg nie chce być kochanym, ani nie przyjmuje ofiary. Do kontemplacji zachęca [nas] liczne grono duchownych i pobudza łaska Boża, ale, odpowiadam, ponieważ kontemplacja jest celem wszystkich naszych działań, konieczne jest do tego celu kierowanie wszelkiego działania. Dlatego poznanie kontemplacji następuje w działaniu, nie tylko z lektury, ale z doświadczenia. Od życia czynnego nie może być odłączone życie kontemplacyjne. Są dwie siostry: Marta czynna i Maria kontemplująca - - Pochwalam królowę odwiedzającą ubogich, pomagającą niesżczęśliwym, wyzwalającą uciśnionych, rządzącą swoimi poddanymi,

4 Por. wyżej s. 31 przypis 1.

5. D. Mieth, Die Einheit von vita activa und vita contemplativa in den deutschen Predigten und Traktaten Meister Eckharts und bei Johannes Tauler. Untersuchungen zur. Struktur des christlichen Lebens. Regensburg 1969. 
wypełniającą wszystkie swoje obowiązki, nie mniej jednakowoż pochwalam ją wielbiącą Boga modłami, w izbie wypoczywającą, we wszystkich sprawach zdającą się na Boga, dla Jego chwały poddającą się wszystkie$\mathrm{mu}$, gorliwie przestrzegającą sprawiedliwości, miłującą czystość. Wszystko to bowiem pochodzi od Boga, jeśli jest należycie uporządkowane i zmierza do dobrego celu, który obejmuje w odpowiednim stosunku dobro bliźniego i chwałę Boga". Swój list dedykacyjny kończy Bitterfeld porównaniem Królowej do gołębicy z arki Noego, która ,wysłana z poleceniem nie siada $z$ krukiem na trupie, ale wracając z zieloną gałązką, stokrotnym owocem władzy królewskiej, trudzi się dla dobra ludzi, a potem codziennie chroni się w ustroniu arki, by odpocząc po znoju, by skupić się po rozproszeniu ducha, by zabezpieczyć się przed pokusami. Gdybyś chciała.stale przebywać $\mathrm{w}$ bezczynności arki, nie zdziałałabyś niczego kcrzystnego dla swojej owczarni, ale także gdybyś chciała ciągle przebywać poza nią, doprowadziłabyś do zupełnego odłączenia się od prawdziwego Noego - Jezusa Chrystusa. A przecież nie możesz gubić samą siebie ze względu na swój lud i dlatego powinnaś powracać do kontemplacji. Nie wolno ci jednak dbać o własne zbawienie z pominięciem ludu. Dlatego powiada apostol: Ja sam żądałem odrzuconym być za braci moich (por. Rom. 9, 3). Nie jest prawdziwą ta matka, która szuka pełnego zadowolenia poza dziećmi" " .

Część pierwszą traktatu poświęca autor życiu kontemplacyjnemu. Rozważa tu następujące kwestie: jaka jest potrzebna dyspozycja do kontemplacji, konieczność pracy, działania, zagadnienie spokoju i odpoczyn$\mathrm{ku}$, potrzeba ciszy, stałości, czasowego odosobnienia, dyspozycje wewnętrzne jak czystość serca, spokój umysłu, medytacja, miłość, modlitwa, kontemplacja i jej przedmiot (Bóg, Wcielenie).

Część drugą swego traktatu przeznaczył Bitterfeld na omówienie życia czynnego, którym, jak pisze, bez kontemplacji można osią̧nąc zbawienie, jeśli się pełni dobro, ale bez działania dobra nie można się zbawić, zaś wszelkie dzieła dobre powstają z praktyki cnót moralnych. Z kolei autor omawia cztery cnoty moralne: roztropność, opanowanie, męstwo, cierpliwość. Cnoty te są drogowskazem w postępowaniu władcy. Przy cnocie opanowania rozprawia o jedzeniu, grach i zabawach, polowaniu, ubiorach, śpiewie, histrionach. Część druga traktatu wzorowana jest na tzw. speculum principis, typowym średniowiecznym traktacie, ukazującym obraz idealnego władcy.

Ogólna koncepcja dzieła została zapewne narzucona Bitterfeldowi. Swieckim i duchownym panom polskim chodziło niewątpliwie o to, aby wykorzystać bogate dyspozycje psychiczne Jadwigi, jej wielkie uzdol-

${ }^{6}$ Powyższy tekst cytujemy $\mathrm{z}$ niewielkimi zmianami stylistycznymi z pracy IM. Gębarowicza (jw. s. 90n). 
nienia i tak ukształtowaną duchowo oraz intelektualnie andegawenkę zatrzymać na tronie polskim. Na wielkość Jadwigi złożyły się nie tylko jej wyjątkowe cechy serca i umysłu, ale również dojrzałość środowiska krakowskiego, które musiało dobrać właściwe środki dla rozwinięcia i uformowania tak pięknej postaci. W tym dziele duchowego i intelektualnego kształtowania młodej Królowej szczególną zasługę należy przypisać ówczesnym biskupom krakowskim: Janowi Radlicy i Piotrowi Wyszowi. W nie mniejszym stopniu przyczynili się do tego miejscowi teologowie $\mathrm{z}$ Bartłomiejem $\mathrm{z}$ Jasła i Stanisławem ze Skarbimierza na czele. Osobną rolę, wartą głębszego na ten temat studium, odegrała tu bliska towarzyszka Jadwigi na dworze wawelskim Elżbieta Melsztyńska.

Dla kaznodziejów-profesorów królowa Jadwiga była symbolem odnowionego Studium Generale. Idea uniwersytetu mimo aktu erekcyjnego wydanego przez Kazimierza Wielkiego była bardzo słaba i niedoceniana przez Polaków, którzy, według opinii Długosza, nie garnęli się zbytnio do nauki. Z tego stanu rzeczy zdawali sobie sprawę pierwsi profesorowie krakowskiej Almae Matris i dlatego, podkreślając ogromne zasługi Jadwigi stwierdzili po prostu, że była ona rzeczywiście domina nostra, mater nostra, soror nostra.

Nierównie wielkie są zasługi Jadwigi-Andegawenki dla Korony Polskiej. W swojej osobie oddawała przybranej ojczyźnie świetny ród dynastyczny, ona też wprowadziła Polskę na widownię europejską, gdzie dotąd nie wiele o naszym kraju wiedziano.

Wszakże celem pierwszorzędnym publikowanych powyżej kazań profesorów krakowskich było zachęcenie kleru, a za jego pośrednictwem całego ludu polskiego do modlitw za duszę Królowej, rozbudzenie czci dla tej wyjątkowej osoby, pełnej świętości, heroizmu, dobroci, bez reszty oddanej ludziom wszystkich stanów. 